\title{
Development of a Dedicated Ethanol Ultra-Low Emission Vehicle (ULEV) System Design
}

G. Bourn, T. Callahan, L. Dodge, J. Mulik, D. Naegeli, K. Shouse, L. Smith, and K. Whitney Southwest Research Institute

San Antonio, Texas

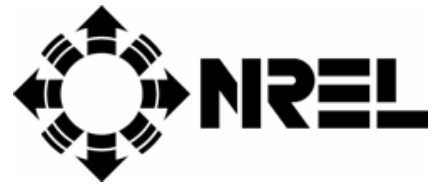

National Renewable Energy Laboratory 1617 Cole Boulevard Golden, Colorado 80401-3393

A national laboratory of the U.S. Department of Energy Managed by Midwest Research Institute for the U.S. Department of Energy under contract No. DE-AC36-83CH10093 


\section{Development of a Dedicated Ethanol Ultra-Low Emission Vehicle (ULEV) System Design}

G. Bourn, T. Callahan, L. Dodge, J. Mulik,

D. Naegeli, K. Shouse, L. Smith, and

K. Whitney

Southwest Research Institute

San Antonio, Texas

NREL Technical Monitor:

C. Colucci

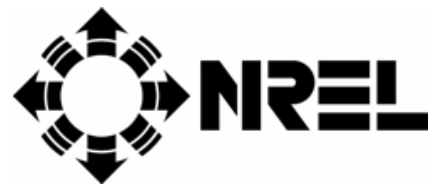

National Renewable Energy Laboratory 1617 Cole Boulevard Golden, Colorado 80401-3393

A national laboratory of the U.S. Department of Energy Managed by Midwest Research Institute for the U.S. Department of Energy under contract No. DE-AC36-83CH10093

Prepared under Subcontract Number YAW-3-12243-01 June 1994 


\section{NOTICE}

This report was prepared as an account of work sponsored by an agency of the United States government. Neither the United States government nor any agency thereof, nor any of their employees, makes any warranty, express or implied, or assumes any legal liability or responsibility for the accuracy, completeness, or usefulness of any information, apparatus, product, or process disclosed, or represents that its use would not infringe privately owned rights. Reference herein to any specific commercial product, process, or service by trade name, trademark, manufacturer, or otherwise does not necessarily constitute or imply its endorsement, recommendation, or favoring by the United States government or any agency thereof. The views and opinions of authors expressed herein do not necessarily state or reflect those of the United States government or any agency thereof. 


\title{
DEVELOPMENT OF A DEDICATED ETHANOL ULTRA-LOW EMISSION VEHICLE (ULEV) - SYSTEM DESIGN
}

\author{
by \\ Gary D. Bourn \\ Timothy J. Callahan \\ Lee G. Dodge \\ John Mulik \\ David W. Naegeli \\ Kenneth R. Shouse \\ Lawrence R. Smith \\ Kevin A. Whitney \\ Project Manager: Lee G. Dodge \\ Southwest Research Institute \\ San Antonio, Texas 78228-0510 \\ Technical Monitoring by \\ Christopher P. Colucci and Brent K. Bailey \\ National Renewable Energy Laboratory \\ Golden, Colorado \\ and \\ John A. Russell \\ U.S. Department of Energy \\ Office of Transportation Technology \\ Washington, D.C. \\ Subcontract No. YAW-3-12243-01 \\ SwRI Project No. 03-5901
}

November 1994

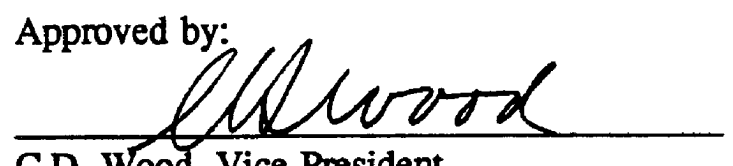

C.D. Wood, Vice President

Engine, Fuel, and Vehicle Research Division 


\section{Preface}

This work was conducted by Southwest Research Institute (SwRI), San Antonio Texas, under Subcontract No. YAW-3-12243-01, SwRI project number 03-5901 for the U.S. Department of Energy (DOE) in Washington, D.C, and the National Renewable Energy Laboratory (NREL) in Golden, Colorado. The contributions of technical monitors Christopher P. Colucci and Brent K. Bailey of NREL, John A. Russell of DOE, and subcontract administrator Emest G. Oster of NREL are gratefully acknowledged. The expertise of Ms. Jo Ann Brown in preparing this report is also greatly appreciated.

The objective of this 3.5 year project is to develop a commercially competitive vehicle powered by ethanol (or ethanol blend) that can meet Califomia's ultra-low emission vehicle (ULEV) standards and equivalent corporate average fuel economy (CAFE) energy efficiency for a light-duty passenger car application. The definition of commercially competitive is independent of fuel cost, but does include technical requirements for competitive power, performance, refueling times, vehicle range, driveability, fuel handling safety, and overall emissions performance.

This report summarizes a system design study completed after six months of effort on this project. The design study resulted in recommendations for ethanol-fuel blends that shall be tested for engine lowtemperature cold-start performance and other criteria. The study also describes three changes to the engine, and two other changes to the vehicle to improve low-temperature starting, efficiency, and emissions. The three engine changes are to increase the compression ratio, to replace the standard fuel injectors with fine spray injectors, and to replace the powertrain controller. The two other vehicle changes involve the fuel tank and the aftertreatment system. The fuel tank will likely need to be replaced to reduce evaporative emissions. In addition to changes in the main catalyst, supplemental aftertreatment systems will be analyzed to reduce emissions before the main catalyst reaches operating temperature. 


\section{Executive Summary}

Ethanol is attractive as an alternative fuel for spark-ignition engines for a variety of reasons. First, it is a renewable fuel, derivable from biomaterials. Many altemative fuels are derived from petroleum, and their long-term potential is therefore limited by the availability of petroleum. Second, ethanol has an average octane number $((\mathrm{R}+\mathrm{M}) / 2)$ of about 102 , compared to about 87 for regular grades of gasoline. The higher octane number implies greater resistance to knock, allowing for higher compression ratios which produce greater cycle (and therefore fuel) efficiency. Third, since ethanol is derived from biofuels, it may be argued that there is no net increase in greenhouse gases. This is in sharp contrast to petroleum-fueled vehicles, and especially natural gas-powered vehicles that typically have low nonmethane hydrocarbon emissions, but high emissions of methane, which is a significant greenhouse gas. Fourth, ethanol is nontoxic, except when toxins are added to prevent human consumption. Fifth, the fuel is naturally low in evaporative emissions, although in practice this potential advantage is offset with the addition of gasoline additives to increase the vapor pressure for starting and fuel tank safety. Sixth, the reactivity factor (potential for exhaust products to form ozone) for ethanol is significantly less than for gasoline, with preliminary estimates being about 0.68 (Marshall, 1994) that of standard gasoline. Seventh, the principal emissions are unburned ethanol and acetaldehyde, formed in the first oxidation step of ethanol, making a simpler mix of gases that must be treated in the exhaust catalyst than those produced by gasoline combustion.

Ethanol also presents engineering challenges that are present with any new fuel. For ethanol, lowtemperature cold-starting is a problem, as is fuel tank flammability. The energy content of ethanol is about 63 percent that of gasoline, decreasing range or increasing fuel tank size. Current costs of ethanol are high enough to make it non-competitive with gasoline, although encouraging results are being obtained in reducing costs.

Southwest Research Institute (SwRD) has been contracted by the U.S. Department of Energy (DOE) and the National Renewable Energy Laboratory (NREL) to develop a dedicated ethanol or ethanol-blend fueled ultra-low emissions vehicle (ULEV). This vehicle must be competitive with conventional gasolinepowered vehicles in cost, reliability, and performance, with the exception of fuel cost.

Neat ethanol (ethanol without additives) presents a number of serious problems to use in spark-ignition engines. The most serious is that engines may not be started on neat ethanol at temperatures below about $10^{\circ} \mathrm{C}$. This problem is usually addressed by adding gasoline to the fuel to provide more volatile components that will evaporate for low-temperature cold-starting. However, this approach is much less effective for ethanol than for methanol, and will require serious attention. In addition, the use of volatile fuel components to increase vapor pressure for cold-starting are detrimental to the naturally low evaporative emissions characteristics of ethanol. Material compatibility is another concem with the use of ethanol fuel. Generally, most of the material changes determined to be suitable for methanol are also suitable for ethanol, but some elastomers compatible with methanol are not compatible with ethanol. Fuel tank flammability with neat ethanol fuel is a concem because the fuel-air mixture in the gas tank is flammable over a temperature range of about $9^{\circ} \mathrm{C}$ to $42^{\circ} \mathrm{C}\left(48^{\circ} \mathrm{F}\right.$ to $\left.108^{\circ} \mathrm{F}\right)$. The addition of gasoline to increase the volatility for cold-starting helps lower the temperature range where the fuel mixture is flammable. Again, the increased volatility is contrary to minimizing evaporative emissions. For methanol, the lack of flame luminosity is considered a safety problem, but the increased flame luminosity of ethanol obviates the need for any additives to increase luminosity. Thus, the addition of gasoline or other light ends helps cold-starting and fuel tank flammability issues, but it simultaneously degrades significantly the naturally low evaporative emissions characteristics of ethanol. 
This report provides specifications for a baseline E-80 (80 percent ethanol, 20 percent gasoline) fuel. Also, a matrix of ethanol blends with $\mathrm{nButane}$, nPentane, iPentane, $\mathrm{C}_{5} \mathrm{C}_{6}$ isomerate, diethyl ether, and unleaded gasoline is provided. These fuel blends will be evaluated at two different concentration levels each for cold-starting capability with the engine in a refrigerated chamber. Flammability tests shall also be conducted on each fuel blend.

More than 60 percent of the ozone forming potential hydrocarbons for an ethanol-fueled engine consist of unburned ethanol and acetaldehyde (Kroll, 1993), and it is estimated that about 90 percent of these are emitted during the first two or three minutes of operation. Therefore, reducing unbumed fuel during startups, and especially cold-starts is essential to reducing these non-methane organics (NMOG) and meeting the California ULEV standards. Increasing proportions of the automobiles sold in California must meet the California ULEV standards, and other parts of the United States may adopt some or all of California's emissions standards for automobiles.

The approach being taken in this project for engine and vehicle development to meet ULEV standards involved the use of two vehicles, one with minimal modifications, and the second with substantial modifications to take full advantage of the combustion characteristics of ethanol. Both vehicles are based on 1993 Ford Taurus flexible fuel vehicles (FFV) with the 3.0-liter, V-6, Vulcan engine. These vehicles are designed to run on M85 (85 percent methanol, 15 percent gasoline) or gasoline, or any mixture of M85 and gasoline. The emissions of these standard vehicles are quite good on these fuels, although they do not meet ULEV standards. The first vehicle with minimal modifications shall be used to develop the advanced aftertreatment system. The second vehicle shall include the advanced aftertreatment, plus three major engine changes to optimize the vehicle for the use of ethanol fuel.

In modem spark-ignition engines, a key to meeting emissions standards is an effective aftertreatment system. This will be especially true in meeting ULEV standards, where rapid heat-up and operation of the exhaust catalyst is essential. The engine-out emissions are usually worst at engine cold-start, and the catalyst must become effective as soon as possible to process these high emissions levels. The first Ford Taurus shall be used to examine advanced aftertreatment systems. Three systems are under consideration for the exhaust catalyst including an electrically heated catalyst (EHC), a burner heated catalyst, and an unheated start-up catalyst. One of these shall be incorporated in the demonstration vehicle. The second planned change to the standard FFV is the replacement of the standard fuel tank and possibly other portions of the fuel system to reduce evaporative emissions associated with fuel permeation through walls of components in the fuel system. It may also be necessary to augment parts of the evaporative emissions control system.

The second Ford Taurus vehicle shall be used for more extensive modifications, including engine changes, and then the advanced aftertreatment system shall be added from the first vehicle. The first of the engine changes is the replacement of the standard fuel injectors with fine-spray, air-assist, port fuel injectors. The fine-spray fuel injectors should increase the transport efficiency of the fuel into the cylinder, avoiding one limitation to cold-starting, the requirement of prevaporization in the intake manifold. A major benefit of this approach is to reduce the volatility requirements of the fuel, retaining at least some of the naturally low volatility of neat ethanol. The second of the three major engine changes involves increasing the compression ratio to increase the cycle efficiency of the engine, made possible by the high octane number of ethanol. The biggest advantage of increased compression is the increase in cycle efficiency, although slight improvements in low-temperature cold-starting and improved combustion efficiency are anticipated due to increased compression heating of the fuel-air mixture. However, increased compression ratio is expected to increase both nitric oxide and hydrocarbon emissions. The third engine change is necessitated by the first two, a custom engine control system. Changes in the fuel injection and engine compression ratio shall change engine control strategies, requiring the use of an SwRI engine/vehicle controller. 
Original equipment manufacturers (OEM) do not allow their control systems to be modified by outside parties. The engine changes are directed at reducing unbumed fuel during start-ups, especially cold-starts.

This report provides details on how the above changes shall be accomplished. It also discusses the anticipated effects of design changes on engine performance and emissions, and the tradeoffs involved. 


\section{TABLE OF CONTENTS}

Task 1. Fuel Formulation and Preparation $\ldots \ldots \ldots \ldots \ldots \ldots \ldots \ldots \ldots \ldots$

Fuel Selection Criteria $\ldots \ldots \ldots \ldots \ldots \ldots \ldots \ldots \ldots \ldots \ldots \ldots \ldots \ldots \ldots \ldots$

Engine Performance $\ldots \ldots \ldots \ldots \ldots \ldots \ldots \ldots \ldots \ldots \ldots \ldots \ldots \ldots \ldots \ldots \ldots \ldots$

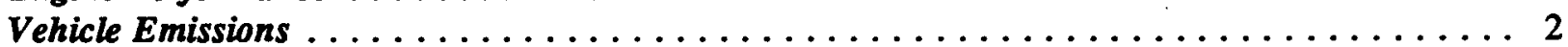

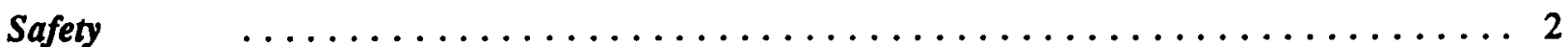

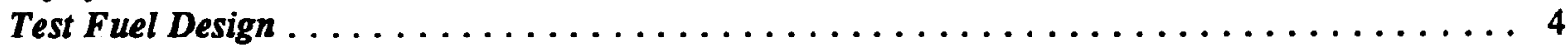

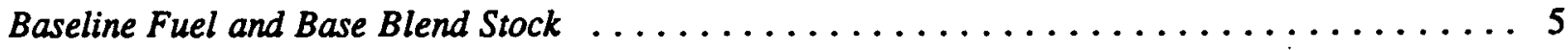

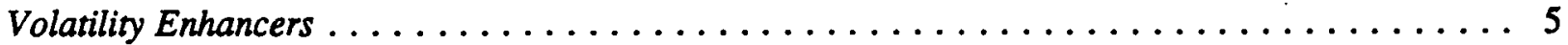

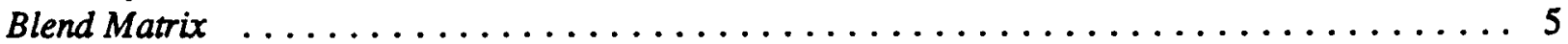

Lubrication in Alcohol-Fueled Vehicles $\ldots \ldots \ldots \ldots \ldots \ldots \ldots \ldots \ldots \ldots$

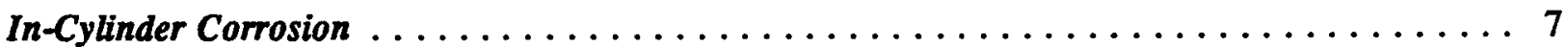

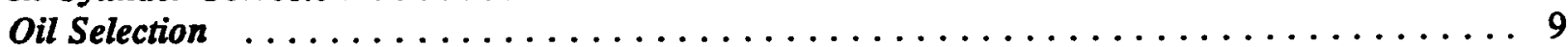

Task 2. Material Compatibility with Ethanol Blends $\ldots \ldots \ldots \ldots \ldots \ldots$

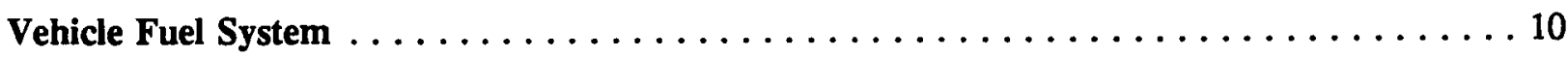

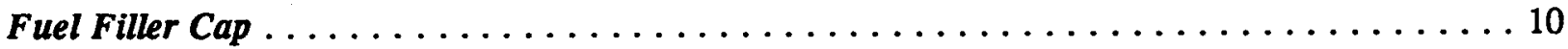

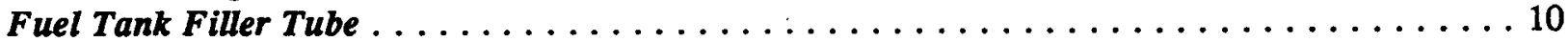

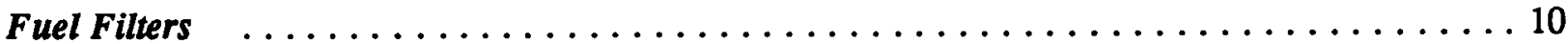

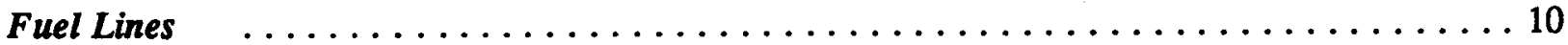

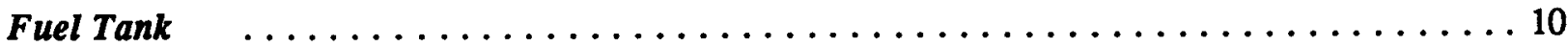

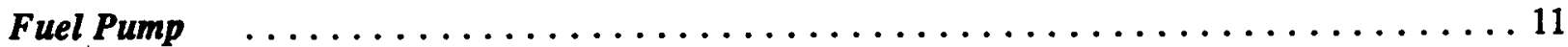

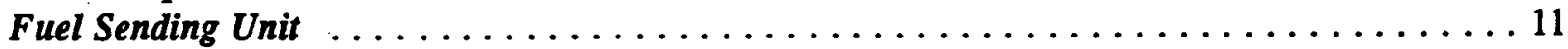

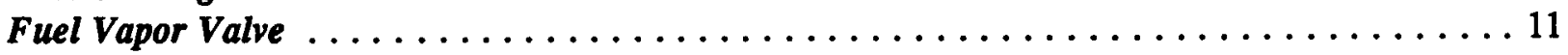

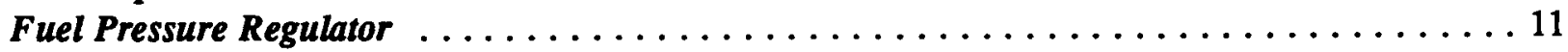

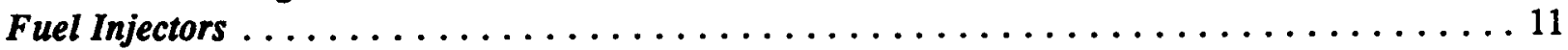

Ethanol Fuel Distribution, Storage, and Dispensing $\ldots \ldots \ldots \ldots \ldots \ldots \ldots \ldots \ldots$

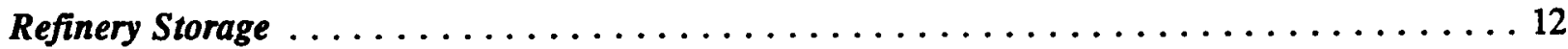

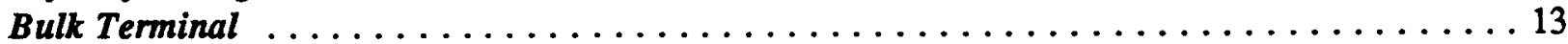

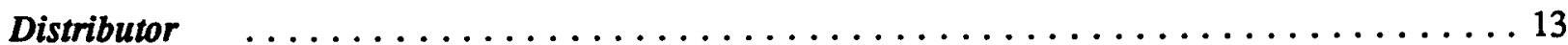

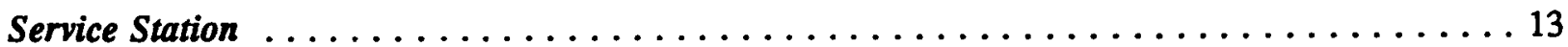

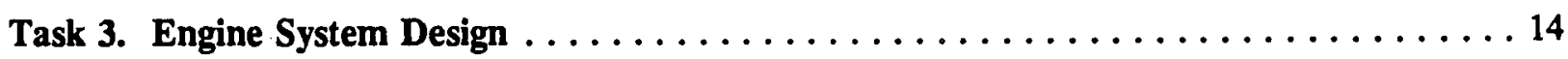

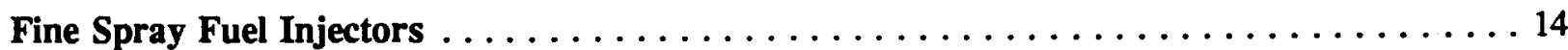

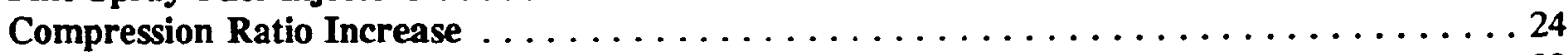

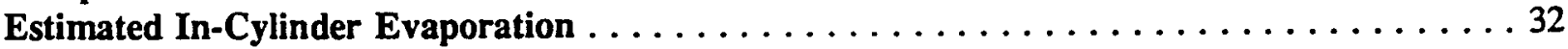




\section{TABLE OF CONTENTS (Cont'd)}

Page

Engine Control System Design $\ldots \ldots \ldots \ldots \ldots \ldots \ldots \ldots \ldots \ldots \ldots \ldots \ldots \ldots \ldots \ldots$

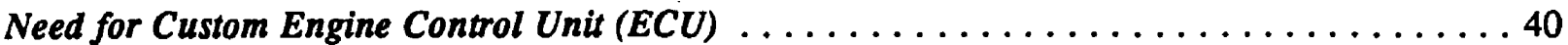

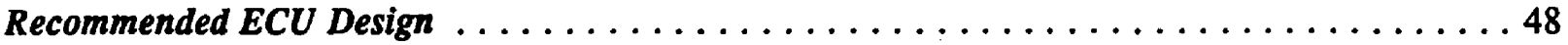

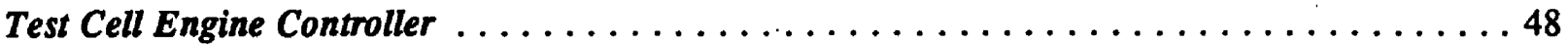

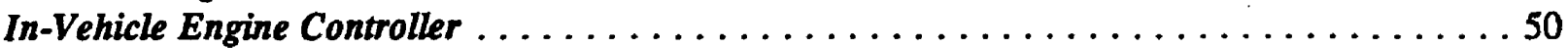

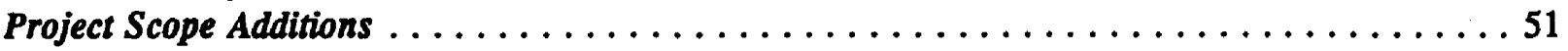

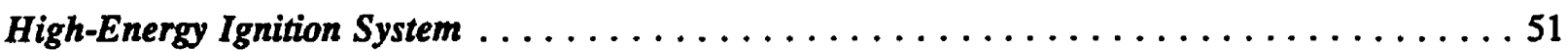

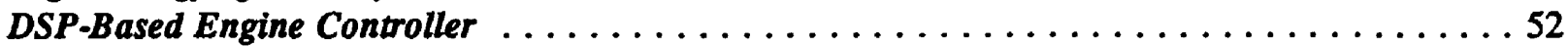

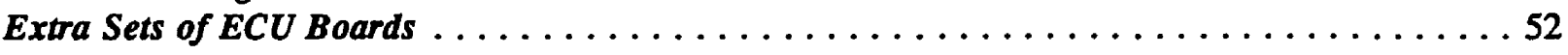

Task 4. Emissions Control System Design $\ldots \ldots \ldots \ldots \ldots \ldots \ldots \ldots \ldots \ldots \ldots \ldots \ldots \ldots \ldots \ldots$

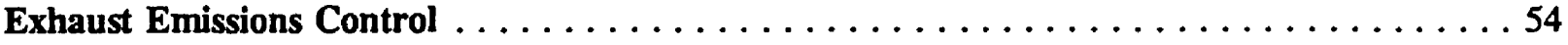

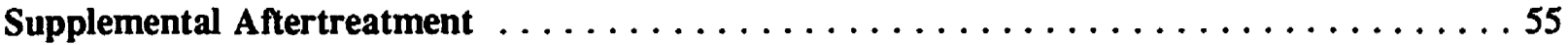

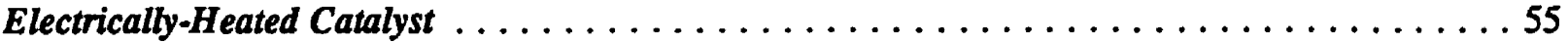

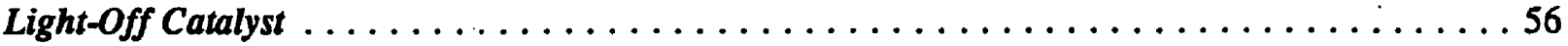

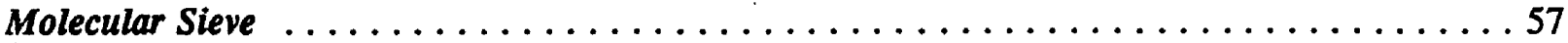

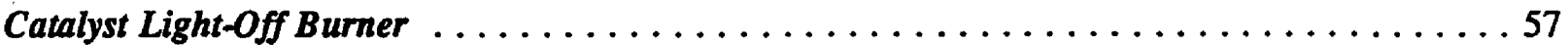

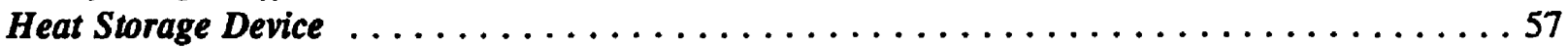

Summary - Supplemental Aftertreatment Systems $\ldots \ldots \ldots \ldots \ldots \ldots \ldots \ldots \ldots \ldots \ldots$

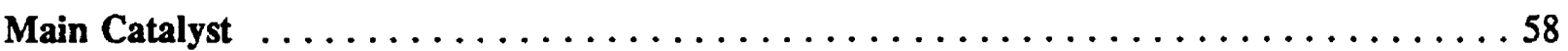

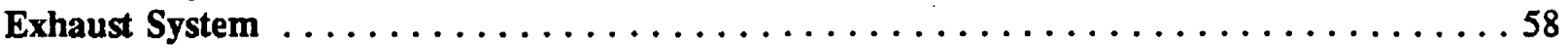

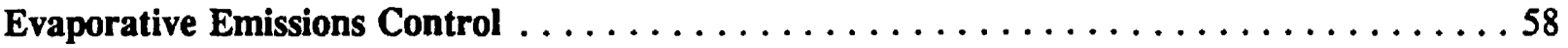

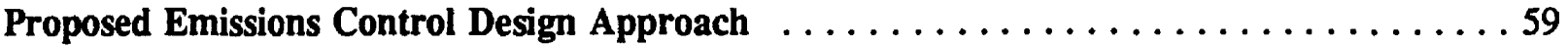

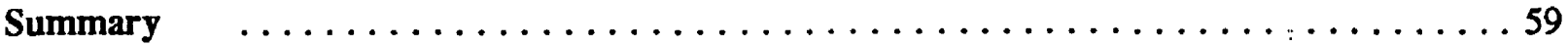

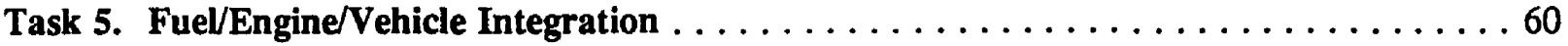

Task 6. Fuel/Engine/System Design Optimization $\ldots \ldots \ldots \ldots \ldots \ldots \ldots \ldots \ldots \ldots \ldots$

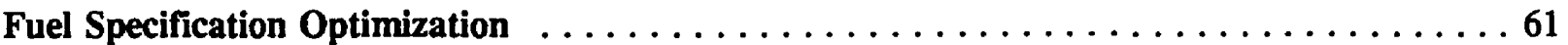

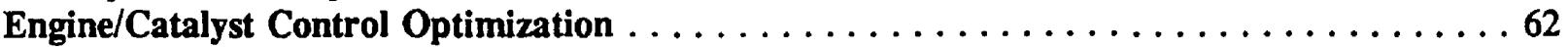

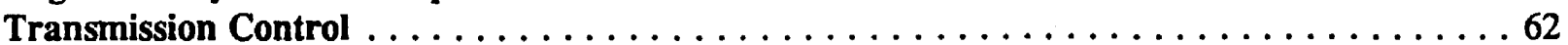

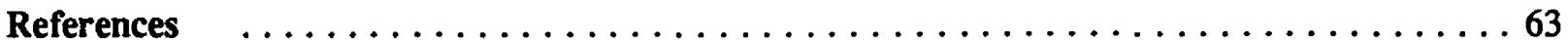

Appendix A - Custom Board Designs

Custom MC68HC11 Microcontroller Board

Custom 67F687 Engine Controller Board

Custom Injector/Spark Driver Board 


\section{LIST OF FIGURES}

Figure

Page

1 Simulated cold-starting minimum temperatures based on laboratory measurements ... 2

2 Vapor space flammability limits over liquid fuels $\ldots \ldots \ldots \ldots \ldots \ldots \ldots$

$3 \quad$ Flammability test apparatus $\ldots \ldots \ldots \ldots \ldots \ldots \ldots \ldots \ldots \ldots \ldots \ldots$

$4 \quad$ Luminosity measurement apparatus $\ldots \ldots \ldots \ldots \ldots \ldots \ldots \ldots \ldots \ldots$

5 Effect of oil sump temperature on engine iron wear with various fuels $\ldots \ldots \ldots \ldots$

6 Vapor pressure of neat ethanol as a function of temperature $\ldots \ldots \ldots \ldots \ldots \ldots$

7a Air and fuel flow past the intake valve of typical engine. Small drops tum with air,

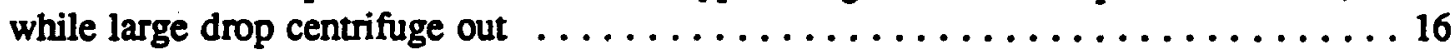

Tb Simulation of air and fuel flow past intake valve. Air assumed to have turned $45^{\circ}$ and drag calculations performed with TESS to determine which drops tum with air .. 16

8 Computed drop trajectories for fine-spray injector flow past intake valve (6.5-mm by $20-\mathrm{mm}$ section), for drop sizes of $2 \mu \mathrm{m}$ (at top), $5 \mu \mathrm{m}, 10 \mu \mathrm{m}$, $15 \mu \mathrm{m}$ and $30 \mu \mathrm{m}$ (at bottom), representing smallest 20 percent by volume segment of spray to largest 20 percent, for methanol spray with initial spray characteristics at injector tip of SMD $=4.5 \mu \mathrm{m}$ and Rosin-Rammler $\mathrm{N}$ parameter of 1.38, drop velocity at intake valve of $13 \mathrm{~m} / \mathrm{s}$, and air velocity (due to injector air jet) of $10 \mathrm{~m} / \mathrm{s}$

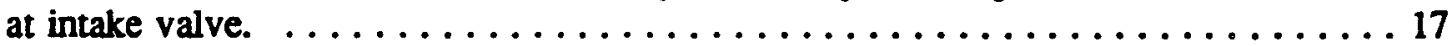

$9 \quad$ SwRI intemal mix, air-assist injector caps . . . . . . . . . . . . . 19

10 SwRI intemal mix, air-assist injector cap mounted on conventional pintle injector . . . 20

11 Sub-atmospheric pressure spray characterization chamber $\ldots \ldots \ldots \ldots \ldots \ldots \ldots$

12 Atomization quality (cross-section average SMD) versus differential air pressure for SwRI 1.0-mm exit-hole diameter, intemal-mix, air-assist injector spraying methanol

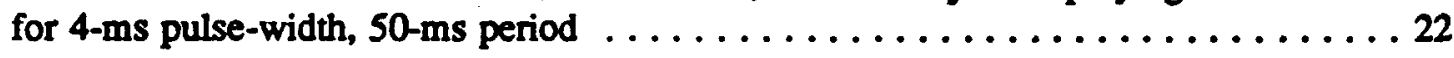

13 Atomization quality (cross-section average SMD) versus differential air pressure for SwRI 1.0-mm exit-hole diameter, intemal-mix, air-assist injector spraying methanol for 10 -ms pulse-width, 50 -ms period $\ldots \ldots \ldots \ldots \ldots \ldots \ldots \ldots \ldots \ldots \ldots$

14 Atomization quality (cross-section average SMD) versus atomizing air flow for SwRI 1.0-mm exit hole diameter, internal-mix, air-assist injector spraying methanol for

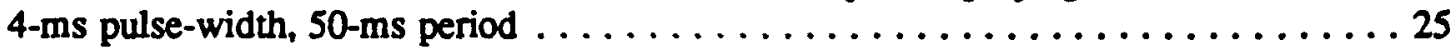




\section{LIST OF FIGURES (Cont'd)}

Figure

$\underline{\text { Page }}$

15 Atomization quality (cross-section average SMD) versus atomizing air flow for SwRI 1.0-mm exit-hole diameter, intemal mix, air-assist injector spraying methanol for

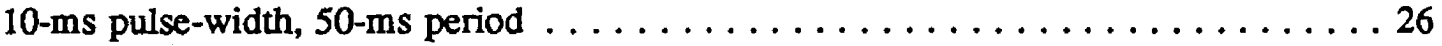

16 Effect of hole size on atomization quality (cross-section average) versus differential air pressure for SwRI single-hole injectors with exit-hole diameters of 1.0-, 1.4-, and 2.0-mm. Methanol, 10-ms pulse-width, 50-ms period . . . 27

17 Comparison of atomization quality (SMDs) versus differential air pressure for three internal-mix, air-assist injectors with exit hole diameters of $1.0-\mathrm{mm}$, 1.4-mm, and 2-mm exit-hole diameters, 10-ms pulse-width, spraying into

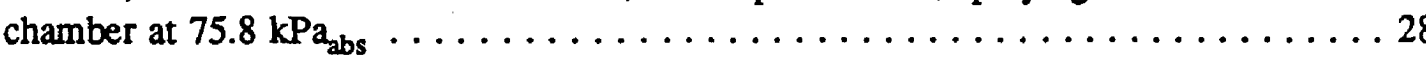

18 Effect of hole size on atomization quality (cross-section average) versus atomizing air mass flow for SwRI single-hole injectors with exit-hole diameters of 1.0-, 1.4-, and $2.0-\mathrm{mm}$. Methanol, 10 -ms pulse-width, 50 -ms period . . . . . . . . . . 29

19 Piston and combustion chamber for Ford Taurus $3.0-$ liter $V-6 \ldots \ldots \ldots \ldots \ldots$

20 Computed in-cylinder evaporation for gasoline (n-heptane) and neat ethanol fuel spray with $\mathrm{SMD}=10 \mu \mathrm{m}$ (Rosin-Rammler $\mathrm{N}=1.5$ ) in Ford Taurus 3.0-liter V-6 cranking at $250 \mathrm{rpm}, 25^{\circ} \mathrm{C}$ air and engine .................. 35

21 Computed in-cylinder evaporation for gasoline (n-heptane) and neat ethanol fuel spray with $\mathrm{SMD}=10 \mu \mathrm{m}$ (Rosin-Rammler $\mathrm{N}=1.5$ ) in Ford Taurus 3.0-liter V-6

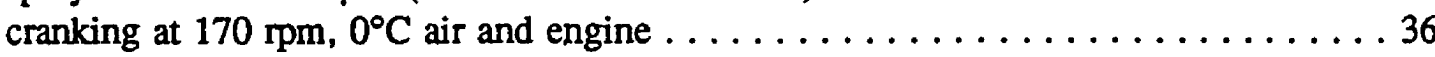

22 Computed in-cylinder evaporation for gasoline (n-heptane) and neat ethanol fuel spray with $\mathrm{SMD}=10 \mu \mathrm{m}$ (Rosin-Rammler $\mathrm{N}=1.5$ ) in Ford Taurus 3.0-liter V-6 cranking

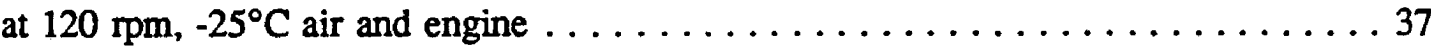

23 Computed in-cylinder gas temperature with gasoline (n-heptane) and neat ethanol fuel spray with $\mathrm{SMD}=10 \mu \mathrm{m}$ (Rosin-Rammler $\mathrm{N}=1.5$ ) for Ford Taurus 3.0-liter V-6

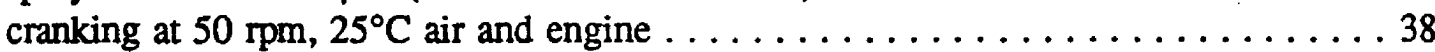

24 Computed in-cylinder gas temperature with gasoline (n-heptane) and neat ethanol fuel spray with $S M D=10 \mu \mathrm{m}$ (Rosin-Rammler $N=1.5$ ) for Ford Taurus 3.0-liter V-6

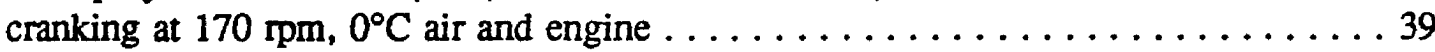

25 Computed in-cylinder hydrocarbons with n-heptane (simulating gasoline) and neat ethanol fuel spray with $S M D=10 \mu \mathrm{m}$ (Rosin-Rammler $\mathrm{N}=1.5$ ) for Ford Taurus 3.0-liter V-6 cranking at $170 \mathrm{rpm}, 0^{\circ} \mathrm{C}$ air and engine 


\section{LIST OF FIGURES (Cont'd)}

Figure

Page

26 Computed $n$-heptane vapor pressures for fuel spray with $\mathrm{SMD}=10 \mu \mathrm{m}$ (Rosin-Rammler $\mathrm{N}=1.5$ ) for Ford Taurus 3.0-liter V-6 cranking at

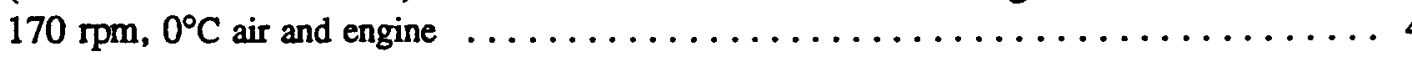

27 Computed neat ethanol vapor pressures for fuel spray with SMD=10 $\mu \mathrm{m}$ (Rosin-Rammler $\mathrm{N}=1.5$ ) for Ford Taurus 3.0-liter V-6 cranking at $170 \mathrm{mpm}$, $0^{\circ} \mathrm{C}$ air and engine

28 Enrichment effect on computed in-cylinder hydrocarbon concentration for n-heptane (simulating gasoline) fuel spray with $\mathrm{SMD}=10 \mu \mathrm{m}$ (Rosin-Rammler $\mathrm{N}=1.5$ ) for Ford Taurus 3.0 liter V-6 cranking at $170 \mathrm{rpm}, 0^{\circ} \mathrm{C}$ air and engine $\ldots \ldots \ldots \ldots 44$

29 Enrichment effect on computed in-cylinder hydrocarbon concentration for neat ethanol fuel spray with $\mathrm{SMD}=10 \mu \mathrm{m}$ (Rosin-Rammler $\mathrm{N}=1.5$ ) for Ford Taurus 3.0-liter V-6 cranking at $170 \mathrm{~mm}, 0^{\circ} \mathrm{C}$ air and engine $\ldots \ldots \ldots \ldots \ldots \ldots \ldots \ldots \ldots \ldots \ldots \ldots \ldots \ldots$

30 Effect of increased compression ratio on computed in-cylinder evaporation for neat ethanol (compared to $n$-heptane) fuel spray with $S M D=10 \mu \mathrm{m}$

(Rosin-Rammler $\mathrm{N}=1.5$ ) for Ford Taurus 3.0-liter V-6 cranking at $170 \mathrm{rpm}$,

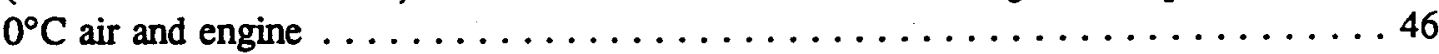

31 The PC-based controller for engine test cell $\ldots \ldots \ldots \ldots \ldots \ldots \ldots \ldots \ldots$

32 Modifications to $\mathrm{PC}$ engine controller for multiple sparks . . . . . . . . . . . . . 49

33 The engine controller for in-vehicle work $\ldots \ldots \ldots \ldots \ldots \ldots \ldots \ldots \ldots \ldots \ldots \ldots$

34 The TMS320C31 DSP-based engine controller $\ldots \ldots \ldots \ldots \ldots \ldots \ldots \ldots \ldots$ 


\section{LIST OF FIGURES (Cont'd)}

Figure

26 Computed n-heptane vapor pressures for fuel spray with $\mathrm{SMD}=10 \mu \mathrm{m}$

(Rosin-Rammler $\mathrm{N}=1.5$ ) for Ford Taurus 3.0-liter $\mathrm{V}-6$ cranking at

$170 \mathrm{rpm}, 0^{\circ} \mathrm{C}$ air and engine

27 Computed neat ethanol vapor pressures for fuel spray with $S M D=10 \mu \mathrm{m}$

(Rosin-Rammler $\mathrm{N}=1.5$ ) for Ford Taurus 3.0-liter V-6 cranking at $170 \mathrm{mpm}$,

$0^{\circ} \mathrm{C}$ air and engine

28 Enrichment effect on computed in-cylinder hydrocarbon concentration for $\mathrm{n}$-heptane

(simulating gasoline) fuel spray with $\mathrm{SMD}=10 \mu \mathrm{m}$ (Rosin-Rammler $\mathrm{N}=1.5$ ) for

Ford Taurus 3.0 liter V-6 cranking at $170 \mathrm{~mm}, 0^{\circ} \mathrm{C}$ air and engine

29 Enrichment effect on computed in-cylinder hydrocarbon concentration for neat ethanol fuel spray with $S M D=10 \mu \mathrm{m}$ (Rosin-Rammler $\mathrm{N}=1.5$ ) for Ford Taurus 3.0-liter V-6

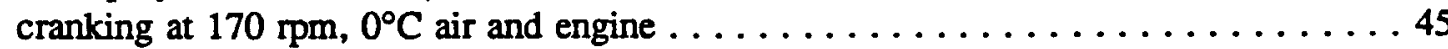

30 Effect of increased compression ratio on computed in-cylinder evaporation for neat ethanol (compared to $\mathrm{n}$-heptane) fuel spray with $\mathrm{SMD}=10 \mu \mathrm{m}$

(Rosin-Rammler $\mathrm{N}=1.5$ ) for Ford Taurus 3.0-liter V-6 cranking at $170 \mathrm{rpm}$,

$0^{\circ} \mathrm{C}$ air and engine

31 The PC-based controller for engine test cell $\ldots \ldots \ldots \ldots \ldots \ldots \ldots \ldots \ldots$

32 Modifications to $\mathrm{PC}$ engine controller for multiple sparks . . . . . . . . . . . . . 49

33 The engine controller for in-vehicle work $\ldots \ldots \ldots \ldots \ldots \ldots \ldots \ldots \ldots \ldots \ldots \ldots$

34 The TMS320C31 DSP-based engine controller $\ldots \ldots \ldots \ldots \ldots \ldots \ldots \ldots$ 


\section{LIST OF TABLES}

Table

Page

1 Specifications for $\mathrm{E}-80$ and $\mathrm{E}-100 \ldots \ldots \ldots \ldots \ldots \ldots \ldots \ldots$

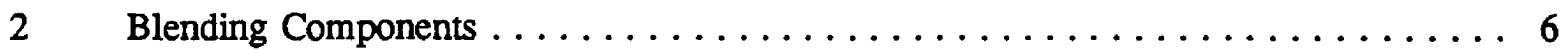

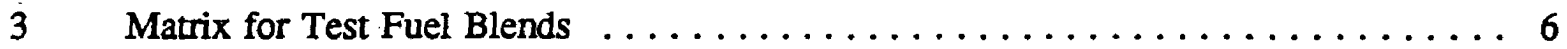

4 Elastomer Test Matrix for Volume Swell and Hardness $\ldots \ldots \ldots \ldots \ldots \ldots$

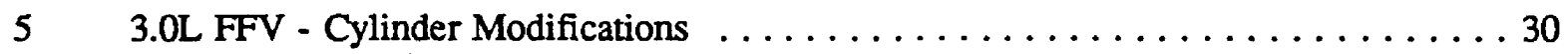

6 Specifications of Ford Taurus 3.0 -liter Engine $\ldots \ldots \ldots \ldots \ldots \ldots \ldots \ldots$

$7 \quad$ Fuel Properties for In-Cylinder Evaporation Calculations $\ldots \ldots \ldots \ldots \ldots \ldots$

8 Comparison of Fuel Effects on Predicted Power and Efficiency $\ldots \ldots \ldots \ldots \ldots$

$9 \quad$ Parts List for Engine Test Cell PC-Based Custom ECU . . . . . . . . . . . . 49

10 Parts List for In-Vehicle PC-Based Custom ECU $\ldots \ldots \ldots \ldots \ldots \ldots \ldots \ldots \ldots$

11 FTP Exhaust Emission for Two Current-Technology Vehicles . . . . . . . . . . 54

12 Califomia 50,000 Mile LEV Program Light-Duty Vehicle Emissions

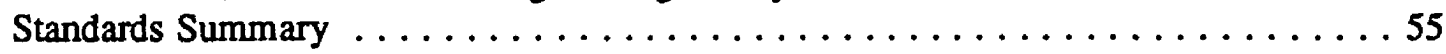

13 Average FTP Exhaust Emissions Reductions for M85-Fueled Vehicles

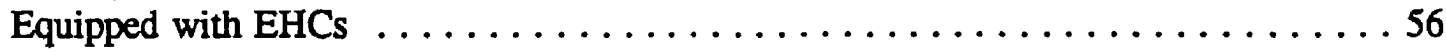

14 FTP Exhaust Emissions Reductions for Three Vehicles Equipped with EHCs ... . . 56 


\section{LIST OF ABBREVIATIONS}

\section{Abbreviation Description}

\begin{tabular}{ll} 
AMA & Automobile Manufacturers Association \\
ASTM & American Society for Testing and Materials \\
BMEP & brake mean effective pressure \\
BTE & brake thermal efficiency \\
CAD & crank angle degree \\
CAFE & corporate average fuel economy \\
DOE & U.S. Department of Energy \\
DSP & digital signal processor \\
ECU & engine control unit \\
EHC & electrically heated catalyst \\
FFV & flexible fuel vehicle \\
FTP & U.S. federal test procedure (light-duty, for emissions testing) \\
IMEP & indicated mean effective pressure \\
LEV & low emission vehicle \\
MFLOP & millions of floating point operations per second \\
MPD & multi-product dispenser \\
NMOG & non-methane organic gases \\
NREL & U.S. National Renewable Energy Laboratories \\
OEM & original equipment manufacturer \\
RAF & reactivity factor \\
RVP & Reid vapor pressure (at 100 F) \\
SMD & Sauter mean diameter \\
SWRI & Southwest Research Institute \\
TDC & top-dead-center \\
TESS & Trajectory and Evaporation of Spray Systems \\
TLEV & transitional low emission vehicle \\
ULEV & ultra-low emission vehicle \\
$\mu$ Hm & micrometers \\
\hline
\end{tabular}




\section{Task 1 - Fuel Formulation and Preparation}

\section{Fuel Selection Criteria}

The selection criteria for choosing an ethanol fuel blend are:

- Engine Performance

- Vehicle Emissions

- Safety

- Material Compatibility (discussed in Task II)

- Fuel Stability (discussed in Task II)

A single ethanol fuel blend utilized in a dedicated vehicle will improve the fuel/vehicle benefits over a flexible fueled vehicle designed to operate on any blend of methanol and gasoline since the engine and aftertreatment system can be optimized for a single fuel.

\section{Engine Performance}

Neat ethanol has an octane number considerably higher than gasoline. The exact differential varies considerably, since the standard octane tests are not completely applicable to ethanol. Typical gasoline octane $(R+M) / 2$ is $87-93$ with ethanol blends being about $96-113(R+M) / 2$ (Sinor and Bailey, 1993). The blending octane values for ethanol vary depending on the concentration and octane of the hydrocarbon. However, it is accepted that ethanol and ethanol blends have excellent antiknock properties. This allows higher compression ratios which improve engine performance and efficiency.

The Reid vapor pressure of neat ethanol is very low, $15-17 \mathrm{kPa}(2.3-2.5 \mathrm{psi})$. An increase in the volatility is an absolute requirement when conventional fuel injection is employed which relies on vaporization in the intake port. Using fine-spray injectors might reduce the requirement for volatility improvers, but will require a higher volatility than neat ethanol. Ethanol, when blended with gasoline, has a non-linear effect on the vapor pressure of the blend. Therefore, the vapor pressure of ethanol blends is not directly proportional to the blend ratio. This makes prediction of vapor pressure somewhat difficult. Ethanol, which has a lower vapor pressure than methanol, $32 \mathrm{kPa}$ (4.6 psi), will require the use of more volatile components than methanol to achieve the same overall vapor pressure. Keller et. al., (1978) studied the effect of hydrocarbon addition to methanol for reducing the cold-starting temperature. The results are shown in Figure 1. As can be seen in Figure 1, to obtain cold-start at a given temperature, a higher concentration of hydrocarbons is required for ethanol as compared to methanol. The effect of fuel blends on low-temperature starting will be measured in Task III.

Engine accelerations using a low volatility fuel present problems similar to those encountered in coldstarting. Again the low vapor pressure of neat ethanol when used in a conventional injection system requires significant amounts of extra fuel to be injected so that the portion of fuel that vaporizes is sufficient to avoid enleanment of fuel-air ratio during acceleration. The use of volatility enhancers should reduce the transient fuel compensation requirements. The use of fine spray fuel injectors should minimize the requirements for volatility enhancers and transient fuel compensation. Engine tests of transient compensation in Task III will include the effects of fuel blends. 


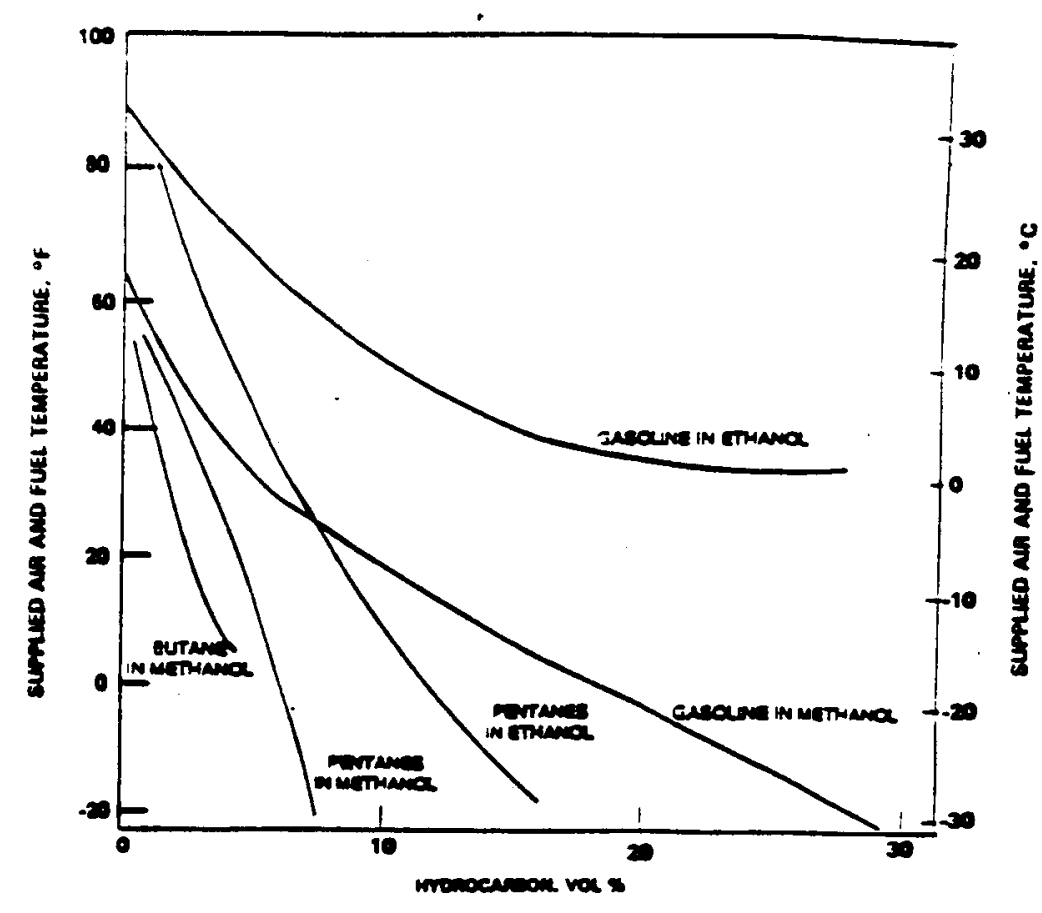

FIGURE 1. SIMULATED COLD-STARTING MINIMUM TEMPERATURES BASED ON LABORATORY MEASUREMENTS

\section{Vehicle Emissions}

A vehicle utilizing ethanol with volatility enhancers is expected have different exhaust and evaporative emissions than neat ethanol. The naturally low evaporative emissions of neat ethanol will be degraded by the use of volatility enhancers. Additionally, the exhaust emissions will change, depending on the material used to increase volatility, and will challenge the development of a catalyst to reduce tailpipe emissions. The volatility enhancers may reduce the emissions during transients by reducing the transient compensation. The evaporative emissions will be measured as described in Task IV.

\section{Safety}

The vapor space over ethanol will normally be in the flammable range at temperatures between $9^{\circ}$ to $42^{\circ} \mathrm{C}$ $\left(48^{\circ}\right.$ to $108^{\circ} \mathrm{F}$ ), similar to the methanol flammable range $7^{\circ}$ to $43^{\circ} \mathrm{C}\left(45^{\circ}\right.$ to $110^{\circ} \mathrm{F}$ ). Anderson (1983) experimentally obtained results for several methanol/hydrocarbon blends which are reproduced in Figure 2 .

Gasoline vapors in an automobile fuel tank are in excess of the rich flammability limit at temperatures above about $-10^{\circ} \mathrm{C}\left(14^{\circ} \mathrm{F}\right)$. The use of volatile hydrocartons lowers significantly the temperature range at which methanol is flammable. A similar lowering of the temperature range at which ethanol is flammable is expected with the use of volatility enhancers.

Fanick, et al. (1980) utilized the test apparatus shown in Figure 3 to measure the flammability limits of numerous methanol hydrocarbon mixtures. The use of volatility enhancers will lower the flammability temperature range of ethanol. The above equipment will be set up to measure the ethanol fuel blends flammability limits. In addition, the vapor pressure will be measured. 


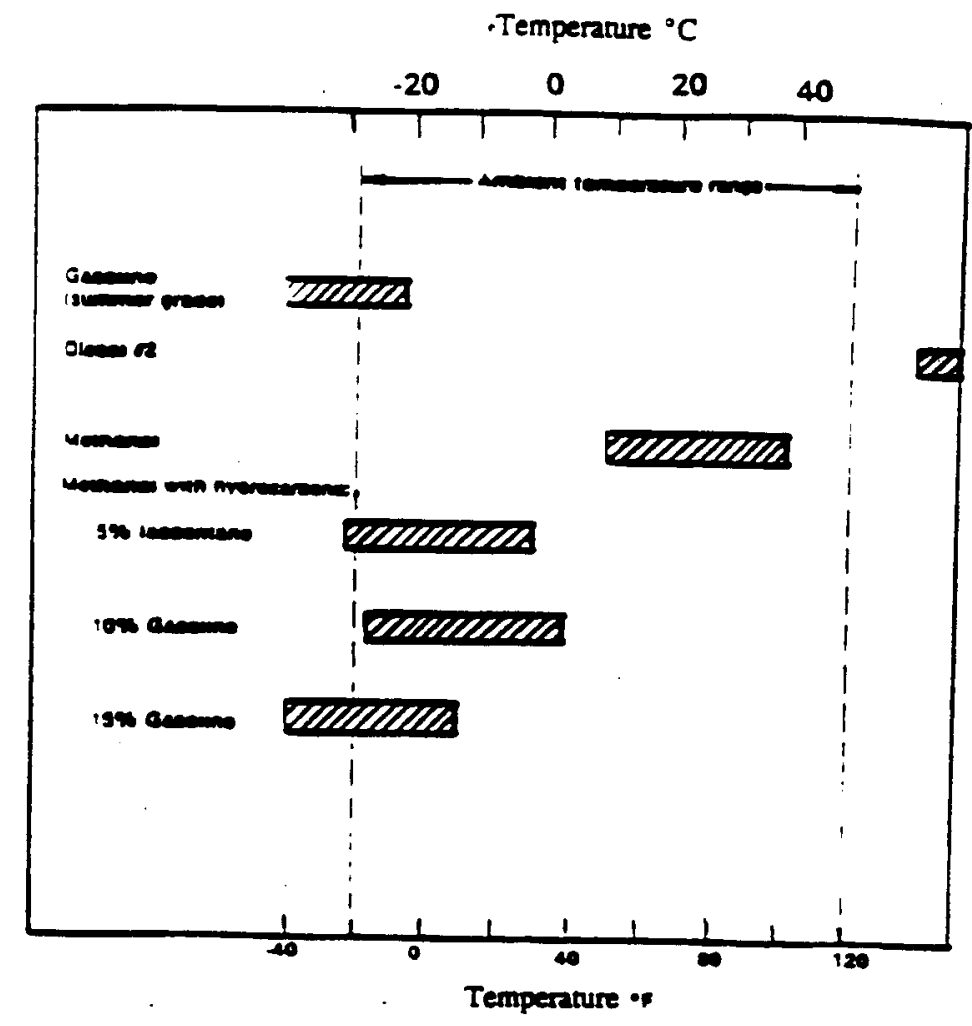

FIGURE 2. VAPOR SPACE FLAMMABILITY LIMITS OVER LIQUID FUELS

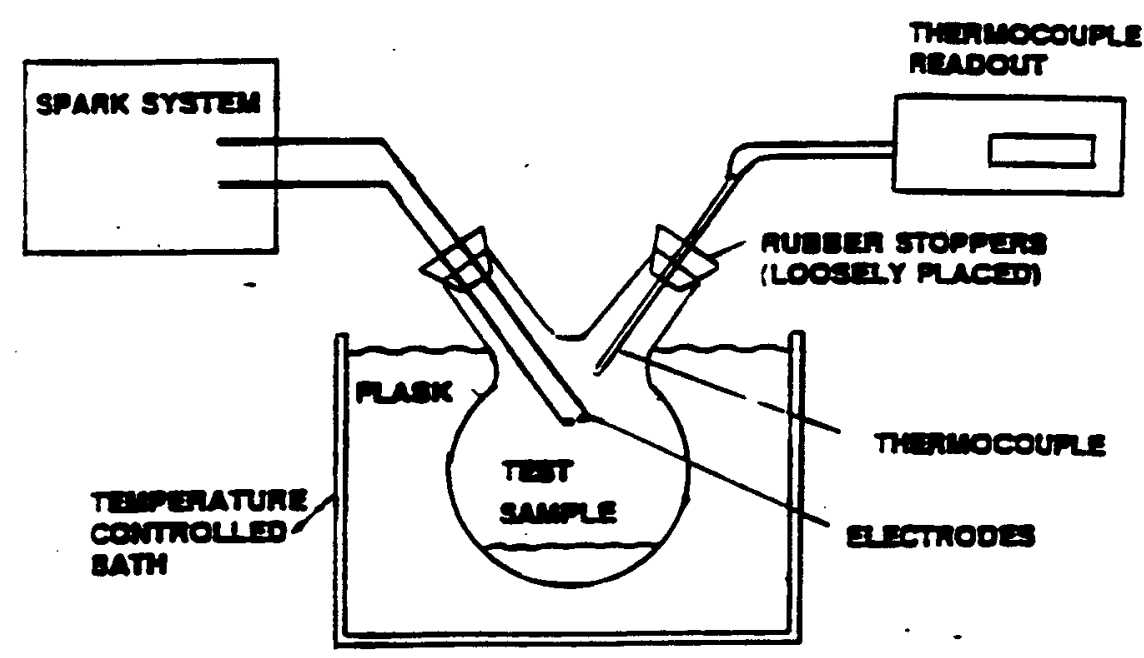

FIGURE 3. FLAMMABILITY TEST APPARATUS 
It is anticipated that the luminosity of ethanol will not present any problem. Ethanol burns with a yellowish flame in contrast to methanol which bums with near invisible flames. The addition of volatility enhancers will improve the luminosity of ethanol. Extensive work was conducted by Fanick, et. al., (1980) utilizing the equipment shown in Figure 4 to study the effect various materials had on methanol flame luminosity. Ethanol was used as the reference material. If necessary, the measurement apparatus can be set up to test ethanol fuel blends.

Based on the above considerations of engine performance, vehicle emissions, and safety issues, the fuel blends and blending agents have been selected and obtained for testing.

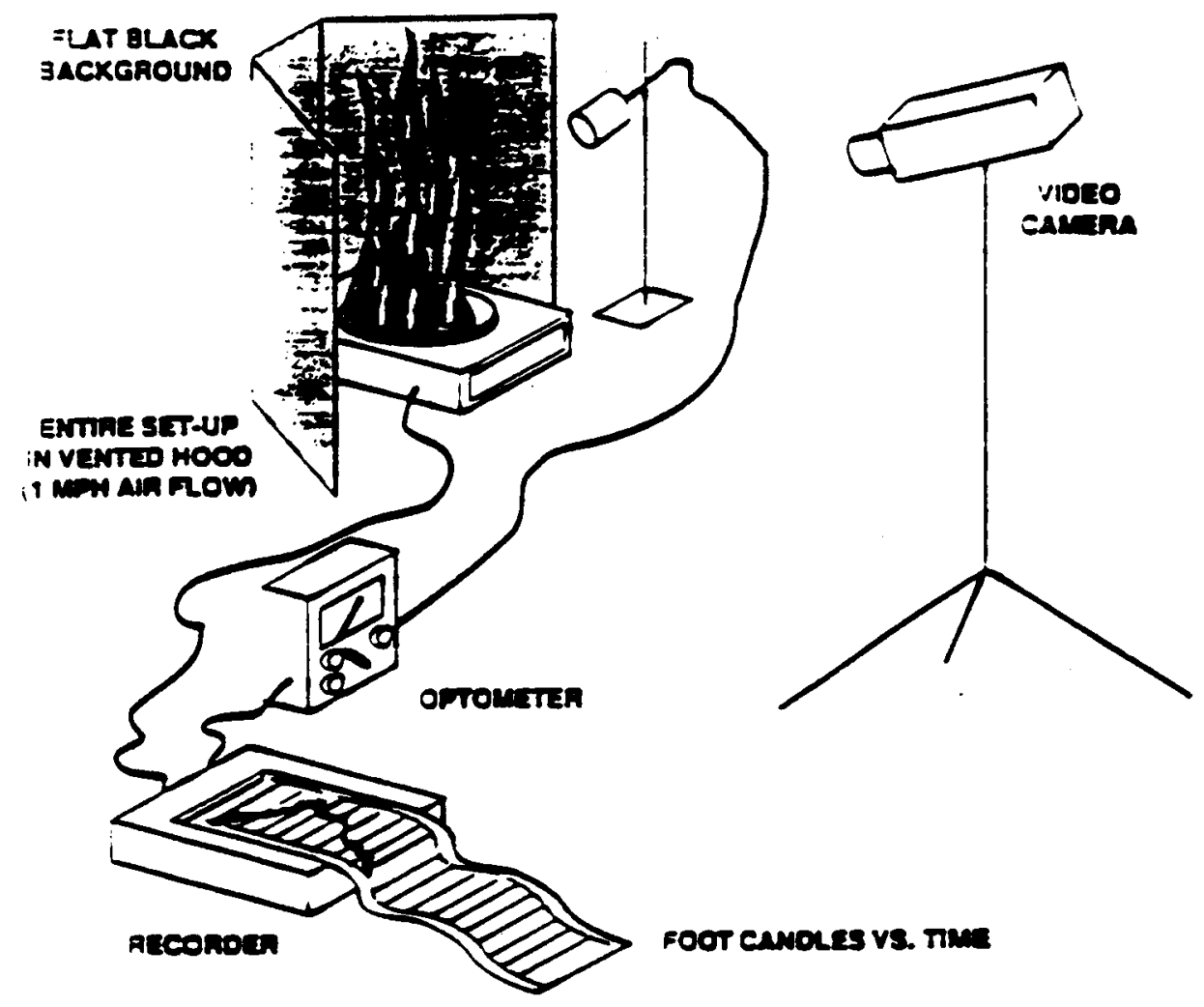

FIGURE 4. LUMINOSITY MEASUREMENT APPARATUS

\section{Test Fuel Design}

As discussed above, the formulation of an ethanol fuel must accommodate various trade-offs, and work synergistically with engine and catalyst design. A high volatility additive is desirable for cold-starting and fuel tank safety, but not for low evaporative emissions or for simplicity of catalyst formulation. A fuels test matrix has been designed to evaluate the tradeoffs using bench tests, engine tests, and finally vehicle tests. This matrix is discussed below. 


\section{Baseline Fuel and Base Blend Stock}

The baseline fuel for the project will be a fuel containing 80 percent ethanol and 20 percent gasoline (E80). This fuel is typically referred to as E-85 if the 5 percent denaturant is considered part of the ethanol for concentration purposes. For this project, the fuel designation will indicate only the actual ethanol concentration. Midwest Grain products has provided 500 gallons of the E-80 fuel from their Atchison, Kansas facility. Specifications of the E-80 are provided in Table 1.

TABLE 1. SPECIFICATIONS FOR E-80 AND E-100

\begin{tabular}{||l|c|c|c||}
\hline & E-80 & E-100 & $\begin{array}{c}\text { Unleaded } \\
\text { Gasoline }\end{array}$ \\
\hline \hline RVP kPa (psi) & $53.7(7.79)$ & $17.1(2.48)$ & $89.3(12.96)$ \\
\hline RON & 104.8 & Unknown & 91.5 \\
\hline MON & 99.3 & Unknown & 83.5 \\
\hline (R+M)/2 & 102.1 & Unknown & 87.5 \\
\hline Distillation, C (F) & & & \\
\hline IBP & $42.8(109)$ & $77.2(171)$ & $22.7(73)$ \\
\hline S0 & $79.4(175)$ & $77.2(171)$ & $89.4(193)$ \\
\hline EP & $178.9(354)$ & $93.9(201)$ & $208.8(408)$ \\
\hline
\end{tabular}

Variations of the volatility will be considered to reflect seasonal requirements similar to summer/winter gasolines. Midwest Grain Products provided 165 gallons of ethanol that will be utilized as the base blend stock. The key fuel properties of these fuels are shown in Table 1.

\section{Volatility Enhancers}

The materials in Table 2 will be used to blend with E-100 to determine the vapor pressure and flammability limits. Sufficient quantities of the components are available to make blend volumes for testing. Additional supplies are readily available.

\section{Blend Matrix}

A test matrix was designed to determine the vapor pressure and flammability characteristics of the test additives and neat ethanol. This matrix is shown in Table 3. The blending levels were selected to cover a range of expected Reid vapor pressures around a target of $51.8 \mathrm{kPa}(7.5 \mathrm{psi})$ fuel. The components range in vapor pressure from $89.7 \mathrm{kPa}$ (13 psi) to $358.8 \mathrm{kPa}$ (52 psi). With the exception of diethyl ether, the components are present in varying concentrations in gasoline used to denature ethanol. This range will allow us to predict other blends with more accuracy, and also indicate possible blending of multiple components with ethanol. 
TABLE 2. BLENDING COMPONENTS

\begin{tabular}{||l|c|c||}
\hline Component & Supplier & Quality \\
\hline n-butane & Phillips & $99.8 \mathrm{Mol} \%$ \\
\hline n-pentane & Phillips & $99.44 \%$ Vol \\
\hline i-pentane & Phillips & $97.07 \%$ Vol \\
\hline C $_{5} \mathrm{C}_{6}$ Isomerate & Texas Refinery & 79\%Mass $\mathrm{C}_{5}$ s/21\% Mass $\mathrm{C}_{6} \mathrm{~s}$ \\
\hline Diethyl Ether & Fischer Chemical & Reagent Grade \\
\hline $\begin{array}{l}\text { Unleaded } \\
\text { Gasoline }\end{array}$ & Midwest Grain & $89 \mathrm{kPa}, 87.5(\mathrm{R}+\mathrm{M}) / 2$ \\
\hline (1) Gasoline used to produce the E-80 fuel blend. \\
\hline
\end{tabular}

TABLE 3. MATRIX FOR TEST FUEL BLENDS

\begin{tabular}{||l|c|c|c|c|c|c|c||}
\hline \multicolumn{7}{|c|}{ Volume Percent } \\
\hline n-butane & - & 15 & - & - & - & - & - \\
\hline n-pentane & - & - & 15 & - & - & - & - \\
\hline i-pentane & - & - & - & 15 & - & - & - \\
\hline C $_{5}$ C $_{6}$ Isomerate & - & - & - & - & 15 & - & - \\
\hline Diethyl Ether & - & - & - & - & - & 15 & - \\
\hline Unleaded Gasoline & - & - & - & - & - & - & 15 \\
\hline Ethanol & 100 & 85 & 85 & 85 & 85 & 85 & 85 \\
\hline & & & Volume Percent & & & \\
\hline n-butane & 5 & - & - & - & - & - & \\
\hline n-pentane & - & 5 & - & - & - & - & \\
\hline i-pentane & - & - & 5 & - & - & - & \\
\hline C5 C6 Isomerate & - & - & - & 5 & - & - & \\
\hline Diethyl Ether & - & - & - & - & 5 & - & \\
\hline Unleaded Gasoline & - & - & - & - & - & 5 & \\
\hline Ethanol & 95 & 95 & 95 & 95 & 95 & 95 & \\
\hline \hline
\end{tabular}


Physically, the blending of the volatile components with ethanol will be conducted in a cold box. The materials will be stored in the cold box prior to blending. Finished blends will also be stored in the cold box until tests are to be performed. This will maintain the quality of the material and integrity of the test results.

\section{Lubrication in Alcohol-Fueled Vehicles}

\section{In-Cylinder Corrosion}

Several investigations (Owens, et al. 1980; Ryan, et al. 1981; Naegeli and Owens, 1984) have shown that the operation of spark-ignition engines on methanol can cause unusually high levels of wear during conditions of warm-up and cold weather operation. Test results from engines have shown that the increased wear occurs principally in the upper cylinder bore and ring areas. Surface profiles and electron micrographs of the cylinder bore and ring surfaces show that corrosion plays an important role in the mechanism.

Laboratory-scale engine tests showed that the wear rate was strongly dependent on the temperature of the oil and coolant, increasing exponentially as the temperature was reduced. Figure 5 shows the effects of oil sump temperature and fuel composition on wear in a 2.3 liter four cylinder engine. The wear rates with unleaded gasoline and anhydrous ethanol are essentially the same, indicating that the wear problem for ethanol is not nearly as acute as it is for methanol. However, when 11 percent water is added to ethanol, there is a significant increase in the wear rate as the engine temperature is lowered. Of course, even with the water present, the wear rate for ethanol is not nearly as high as that for anhydrous methanol. Figure 5 shows that the addition of 11 percent water to methanol causes close to a three-fold increase in the wear rate. These results show that the wear problem with ethanol is of negligible proportion compared to that of methanol.

The temperature dependence and the effect of water on the wear rate is explained by the theory that a liquid fuel layer forms on the cylinder wall when alcohol fuels are inducted into a cold engine. Compared to gasoline, methanol and ethanol have relatively high heats of vaporization and also higher fuel/air ratios for stoichiometric combustion, so when the engine is cold, very little of the fuel evaporates in the cylinder during the intake and compression strokes. For methanol the evaporative cooling is about twice as high as it is for ethanol, so at any one temperature, more liquid methanol is expected to accumulate on the cylinder wall. The theory of a liquid layer on the cylinder wall was supported by a simple model for the evaporation of fuel off a surface. Calculations with the model showed that the temperature dependence of the wear rate was similar to that of the evaporation rate.

In another study, Naegeli (1989), found that corrosive combustion residues were formed when shallow pools of alcohol fuels were bumed in an apparatus designed to simulate the surface of a water-cooled cylinder wall. The combustion residues left on the surface consisted of water, alcohol, formaldehyde, acetaldehyde, formic acid, acetic acid and methylene hydroxyperoxide. The amount of residue formed increased in volume as the surface temperature was lowered. As the coolant temperature was increased, there was a threshold temperature above which no combustion residue would form. The threshold temperature for methanol was about $10^{\circ} \mathrm{C}$ higher than that for ethanol, indicating that combustion residues are much more likely to form with methanol than with ethanol.

The corrosive components of the residues were formic acid, acetic acid and methylene hydroxyperoxide. The methylene hydroxyperoxide was assumed to be formed in the liquid phase by the reaction of formaldehyde with hydrogen peroxide. Acetic acid was produced in relatively low concentrations. It was only found in the combustion residues formed by ethanol and isopropanol. Formic acid was the main 


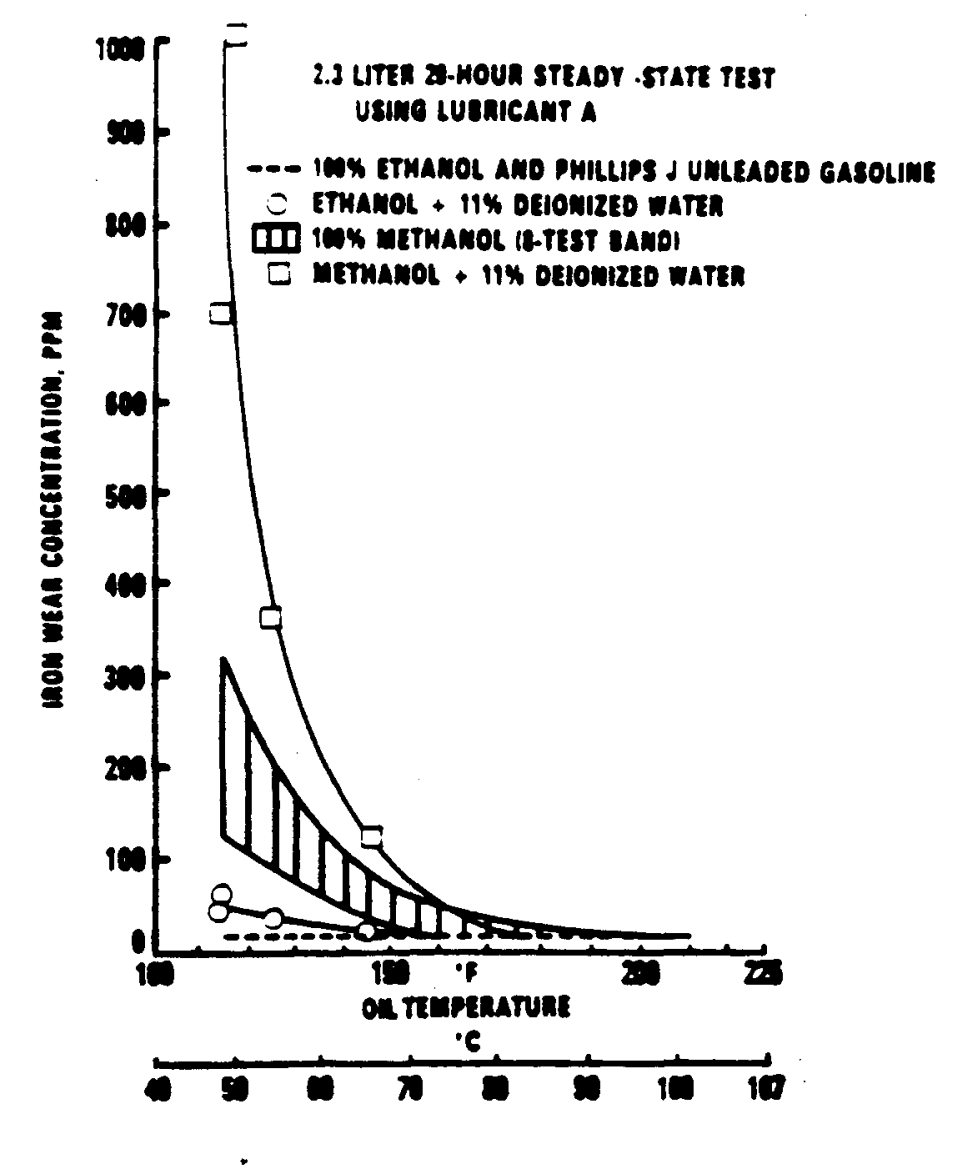

\section{FIGURE 5. EFFECT OF OIL SUMP TEMPERATURE ON ENGINE IRON WEAR WITH VARIOUS FUELS}

cause of corrosion in both methanol and ethanol residues. However, laboratory experiments showed that methylene hydroxyperoxide greatly enhanced the rate of dissolution of iron metal by formic acid in aqueous solution. Based on initial rates of iron dissolution, the presence of methylene hydroxyperoxide increased the rate of corrosion by formic acid by an order of magnitude. Methanol residues contained about four times as much formic acid as those formed from ethanol, but the methylene hydroxyperoxide concentrations were about the same for both alcohols. Naegeli (1989) concluded that the corrosiveness of the methanol residue was about four times as great as that of ethanol residue.

In general, the engine tests showed that cylinder bore and ring wear in engines operating on anhydrous ethanol were comparable with that of engines operating on unleaded gasoline. In other words, the wear problems with ethanol are not expected to be any worse than those with unleaded gasoline if ethanol can be maintained in an anhydrous state. However, keeping ethanol dry is not a simple task. Ethanol combines with about 5 percent water to form an azeotropic mixture that cannot be separated through distillation. Removal of the water during production and preventing subsequent water adsorption during handling could add a significant cost to the fuel. It is clear that the presence of water will exacerbate the wear problem with ethanol, but it is not known with certainty that a water concentration of 5 percent is significant. In the present study the fuel is essentially anhydrous, so cylinder bore and ring wear are not expected to be a problem.

Several lubricant formulations have been developed to combat the wear problems with methanol. These lubricants are usually formulated with characteristics such as high base number and high surface adhesion. 
Because alcohol fuels accumulate on the cylinder wall when the engine temperature is low, there is a tendency to displace or wash the lubricant off the wall. In engines operating on methanol and ethanol, it is important that the lubricant adheres to the cylinder wall and maintains a protective film to prevent contact with corrosive combustion residues.

\section{Oil Selection}

During this project, lubricants recommended for use in methanol-fueled vehicles will be used during all testing and operation. Oil from Petrolube has been selected for this project. During the demonstration phase of the project, the wear metals in the oil will be analyzed to estimate the rate of engine wear. 


\section{Task 2 - Material Compatibility with Ethanol Blends}

Compatibility of fuel system materials with ethanol blends can be divided into two areas. First, the vehicle fuel system and its associated elastomers, plastics, and metals was considered. The second area includes all non-vehicle components, tanks, hoses, and fuel pumps. These areas are discussed below.

\section{Vehicle Fuel System}

The vehicle fuel system has been reviewed and potential material compatibility problems have been identified. The system can be broken down into several sub-systems or components: fuel tank filler cap, fuel tank filler pipe, three fuel filters, fuel lines, fuel pump, fuel vapor valve, fuel pressure regulator, fuel injectors, and a flexible fuel sensor. All of these items are methanol compatible and are anticipated to be compatible with ethanol. Potential additives for the ethanol fuels may pose compatibility problems. These items and associated material are discussed below.

\section{Fuel Tank Filler Cap}

Plastic component with an elastomeric seal to maintain fuel tank pressure and control evaporative emissions.

\section{Fuel Tank Filler Tube}

Metal construction that is coated internally to prevent corrosion. SwRI will verify that the ethanol fuel and fuel additive will not adversely affect this coating.

\section{Fuel Filters}

There are three fuel filters in the system. There is an in-line filter down stream of the fuel pump, mounted to the underbody. There is an in-tank fuel filter made of nylon. Fuel is also filtered at the injector using a metal screen. The materials in these filters will be determined.

\section{Fuel Lines}

The fuel lines on the flexible fuel vehicle are composed of nylon/stainless steel combination with steel push-connect fittings. These fittings use special methanol compatible o-rings. One o-ring is made of GFLT Viton and the second o-ring is made of fluorosilicone. Ethanol compatibility will be verified.

\section{Fuel Tank}

The fuel tank is composed of high density polyethylene with a fluorinated interior surface. The fluorinated surface is resistant to methanol and ethanol. This fuel tank material is likely to be more permeable to fuel vapor than a metal tank or a multilayer coated-metal tank. Permeability is a major issue with regard to the enhanced evaporative emission standards enacted recently by CARB and EPA. The fuel tank is connected to the fuel system using nitrile hoses. These hoses, while compatible with ethanol, mal also be a source of evaporative emissions. While the enhanced evaporative test procedures are not part of the present scope of work, the fuel tank and hoses will be selected to minimize evaporative emissions. 


\section{Fuel Pump}

The fuel pump for the flexible fuel vehicle is rated at $145 \mathrm{l} / \mathrm{hr}(38 \mathrm{gal} / \mathrm{hr})$ at $39 \mathrm{psi}$. It has a nylon filter on the pickup in the fuel tank and a check valve of undetermined composition at the outlet. The check valve maintains fuel line pressure for a period of time following engine shutdown to assist in rapid engine starting. The fuel pump type and material need to be determined. The pump is mounted to the fuel tank and this connection is sealed with a gasket material. The elastomers in the pump and gasket material will be tested for ethanol fuel compatibility.

\section{Fuel Sending Unit}

The fuel sending unit is expected to be compatible with ethanol fuels. Further information will be gathered to verify compatibility.

\section{Fuel Vapor Valve}

The fuel vapor valve is expected to be compatible with ethanol fuels. Further information will be gathered to verify compatibility.

\section{Fuel Pressure Regulator}

The pressure regulator is a spring-loaded diaphragm-type regulator. The diaphragm material is a nitrile coated nylon. Ethanol fuel compatibility will be verified. The inlet of the regulator connects to the fuel supply line with a o-ring connection. These o-rings will be examined for ethanol fuel compatibility.

\section{Fuel Injectors}

There are multiple 0-rings used in the fuel injector body and in the connection of the fuel lines to the injectors. These o-rings are primarily GFLT viton. The majority of fuel wetted components appear to be stainless steel and should pose no compatibility problem with ethanol fuels.

Information from the literature and component suppliers will be used along with several tests that will be conducted on the materials identified above to verify material compatibility. For 0-rings, standard elastomeric test, volume swell and hardness, will be conducted. Samples of the o-rings will be obtained and subjected to aging in fuel samples. The material compatibility test will use methanol as the reference fuel and ethanol and ethanol blends as the test fuels. A typical test matrix is presented in Table 4. The elastomers will be aged in several fuel blends at elevated temperature for various periods of time. Following the aging, volume swell and the change in hardness will be determined using ASTM (American Society for Testing and Materials) procedures.

For elastomers that are present in the system, but not in o-ring form, (i.e. diaphragms and the elastomeric seal on the filler tube cap), there are several options that will be pursued. The initial step will be to obtain samples of the elastomers in the form of o-rings and include them in the test outlined above. The second step is just the monitoring of the performance of the various parts during engine and vehicle testing. If a problem is identified by the static elastomer tests, it is likely to show up during engine testing. Further evaluation could be performed using a functional test. For example, the fuel pump and regulator system could be set up in a flow bench and operated for an extended period of time on the various fuel blends. At this point SwRI does not believe this to be necessary. 
TABLE 4. ELASTOMER TEST MATRIX FOR VOLUME SWELL AND HARDNESS

\begin{tabular}{|c|c|}
\hline $\begin{array}{c}\text { Aging } \\
\text { Temperature }\end{array}$ & $43^{\circ} \mathrm{C}\left(110^{\circ} \mathrm{F}\right)$ \\
\hline Test Fuels & Methanol, Ethanol, Ethanol Blends \\
\hline Aging Period & $14,60,180$ days \\
\hline Materials & Fuel system elastomers in the form of o-rings \\
\hline
\end{tabular}

\section{Ethanol Fuel Distribution, Storage, and Dispensing}

At the kickoff meeting for this project between the NREL project officer and SwRI staff, it was decided that this part of the fuel infrastructure system would be excluded from the experimental part of the effort. However, it was recognized as being an important part of the successful use of ethanol, and warrants discussion of the various parts of the system with which ethanol must interface.

To most consumers, the storage, transportation, and distribution system for fuels is largely transparent. This contrasts with exploration and production which has drilling rigs and publicity about shortages and new discoveries, and fuel processing with the very visible refineries. Our exposure to the distribution infrastructure is from the seemingly endless number of gasoline refueling stations. However, what we see as the "gas station" is the final component of a highly developed system that gets the product from the point of production to the marketplace. Therefore, if ethanol is to live up to its promise as an alternative fuel that can easily fit into the present liquid fuel system, each component of the system needs to be examined to determine potential weaknesses in its interaction with ethanol.

The following is a brief description of links in the finished fuel transportation and distribution chain to provide a perspective for the point at which a dedicated ethanol system can be blended into the existing system. At this point, the discussion will not be made in depth - this is only intended to provide a general overview.

\section{Refinery Storage}

Finished product is stored in large tanks usually having a steel/product interface and enclosed to prevent weathering. Venting can allow breathing to occur, although tank farms are being upgraded for vapor control and recovery. The product must be compatible with the associated piping and pumping equipment and tanks are not necessarily dedicated to a specific product. Insertion of ethanol into the system would probably not occur at this point unless final blending with a hydrocarbon component could most economically be achieved here. Personnel are trained for the specific job, safety, and quality.

From the refinery, fuel is transported to a bulk terminal near the final point of use. Several transportation systems may be employed including pipeline, ship, barge, train tank car, and tanker truck. These systems are composed of a range of materials is encountered and compartment space is not dedicated to specific product. Personnel may range in capability and concern, but are generally trained for specific job requirements, safety, and quality. 


\section{Bulk Terminal}

At the bulk terminal, the fuel is again stored in large, steel tanks. Because most bulk terminals are in the vicinity of large populated areas, tanks are configured with systems for vapor control. Dedicated product tanks are often used, although this may change depending on the season and product demand. Systems are automated to reduce personnel requirements so that products must be compatible with various sensors. Final blending with additives is usually accomplished at this point, and is also automated. Personnel range in skills and training. From this point, fuel may be transported to the bulk storage plant of an independent distributor or marketer, or, if in a large urban area, directly to the service station.

\section{Distributor}

The distributor system handles well over 50 percent of all the fuel sold in the United States. Transportation to the distributor bulk plant is usually by tank truck, although large distributors may be serviced by any of the other transportation systems as well. Final blending of additives into a fuel for specific customer needs (particularly true with diesel fuels) is accomplished at this point. Employee skill level and job/product knowledge are large variables. Transportation from the distributor to the service station is usually by transport truck (also from terminal to service station) although deliveries in rural areas may be made with smaller tank vehicles (bobtails). Dedicated product compartments are not used due to cost of delivery and flexibility required.

\section{Service Station}

Although "service" is no longer available at the majority of the refueling points, this terminology continues to be used. Equipment found at the point of sale can range dramatically from sophisticated vapor recovery at the storage tank and dispensing point, utilizing storage tank materials and lines of fiberglass, to atmospheric vented drops into steel tanks connected to the dispensers with steel lines. In some of the older (1970's) installations, copper lines were used along with suction pumps for the dispenser. Dispensers range from single hose suction pumps to multi-product dispensers (MPD's) fed by fuel pumps in the underground tanks. Dispenser hoses are variations of rubber with a continuous wire for grounding and the nozzle is largely aluminum. In these systems, examples of most engineering materials, in some form, can be found. Tank/product housekeeping varies widely from station to station as do contamination risks. Personnel that interface with these systems are the least well trained of any in the system since they include not only the employees of the station (often entry level positions), but also the consumer. Therefore, education requirements for special handling of a fuel should be kept to a minimum at this point.

In summary, the distribution system is not "high technology", but a fuel within its bounds can experience a wide variety of materials, co-mingling and contamination opportunities, and human experience. Before inserting ethanol into this system, its point of entry and potential interfaces need to be more fully explored. 


\section{Task 3 - Engine System Design}

Changes in engine design relative to current technology for spark-ignition, flexible-fuel vehicles (FFV) are anticipated in three principal areas. First, fine-spray port fuel injectors will be used to increase the transport efficiency between the port fuel injectors and the engine cylinder. These injectors will be designed to "directly" inject fuel through the port, past the intake valve, and into the cylinder. This should reduce low-temperature cold-starting problems and emissions of cold engines associated with conventional engine designs that require fuel vaporization in the intake manifold and port. Second, to take advantage of the very high octane number of E80 (ethanol, 80 percent, gasoline, 20 percent), the compression ratio will be increased. The increased compression ratio will help slightly in increasing fuel evaporation incylinder, and significantly in the cycle efficiency. Third, a new engine controller will be required. These three changes are described in the following sections.

\section{Fine-Spray Fuel Injectors}

A significant limitation in the use of alcohol fuels is the low-temperature, cold-start problem. Conventional spark-ignition engines are based on vaporization of the fuel off the back surface of the intake valve (the tulip), and the hot port walls in the cylinder head prior to the intake stroke. However, at startup the surfaces are cold, and only the light ends of the fuel vaporize. The vapor pressure of neat (pure) ethanol is very low compared with the light ends of gasoline, and Figure 6 shows that the vapor pressure of neat ethanol limits cold-starting to about $18^{\circ} \mathrm{C}$ or above to achieve a flammable mixture based on vaporization in the intake manifold.

Because of the limitation in vapor pressure of ethanol, gasoline or other light ends are added to increase the vapor pressure of the fuel to aid cold-starting. For ethanol, about 20 percent gasoline is typically added, and the mixture is termed E-85, something of a misnomer. Ethanol is denatured with 5 percent gasoline, and then 15 percent gasoline is added to the denatured ethanol. However, as discussed in the Task 1 section, the addition of gasoline to ethanol does not reduce the minimum temperature for coldstarting for ethanol mixtures nearly as effectively as for methanol mixtures. It may be necessary to use pentanes or butanes or some other components more volatile than gasoline. However, this increases problems with evaporative emissions and potential vapor lock in lines. Thus, an altemative approach will be evaluated in this project.

The alternative approach to providing enhanced low-temperature, cold-starting is to avoid the requirement for fuel vaporization in the intake manifold, and instead inject the fuel as a liquid spray into the cylinder. The most straightforward way to accomplish this is with direct in-cylinder injection. However, most current production gasoline engines do not use direct in-cylinder injection, and cannot be easily converted into such a design. Rather, current engines use port fuel injection, or in some cases, throttle body injection. Therefore, the approach that will be used in this project is to produce sequentially timed, port fuel injectors that produce very fine drop sizes so that the fuel spray will follow the air stream into the engine cylinder without fuel deposition on the intake port and intake valve.

To estimate the drop sizes required to follow the air stream past the intake valve without depositing out on the valve, calculations were made with the SwRI fuel spray model TESS CTrajectory and Evaporation of Spray Systems). The flow problem is illustrated in Figure 7a, which shows that the air stream must turn roughly $45^{\circ}$ in flowing past the intake valve into the engine. This geometry was simplified to that shown in Figure $7 \mathrm{~b}$ for the TESS calculations. Predicted trajectories for a fine-spray air-assist injector spraying methanol fuel with an SMD of about 4.5 micrometers are shown in Figure 8. These results show that drops smaller than about 20 micrometers have a high probability of evaporating or following the airstream into the cylinder, while larger drops will have a higher probability of colliding with the intake 


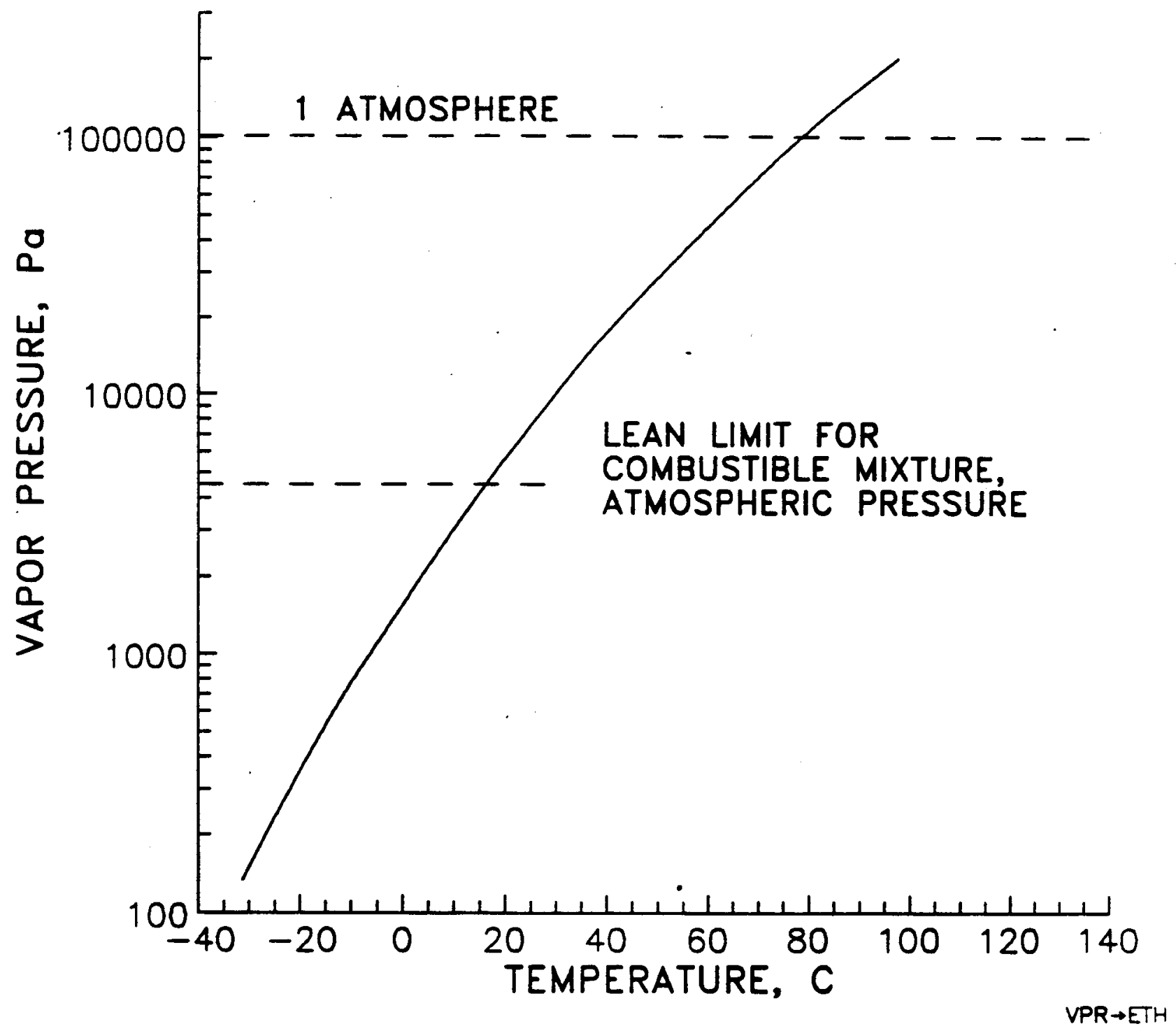

FIGURE 6. VAPOR PRESSURE OF NEAT ETHANOL

AS A FUNCTION OF TEMPERATURE 


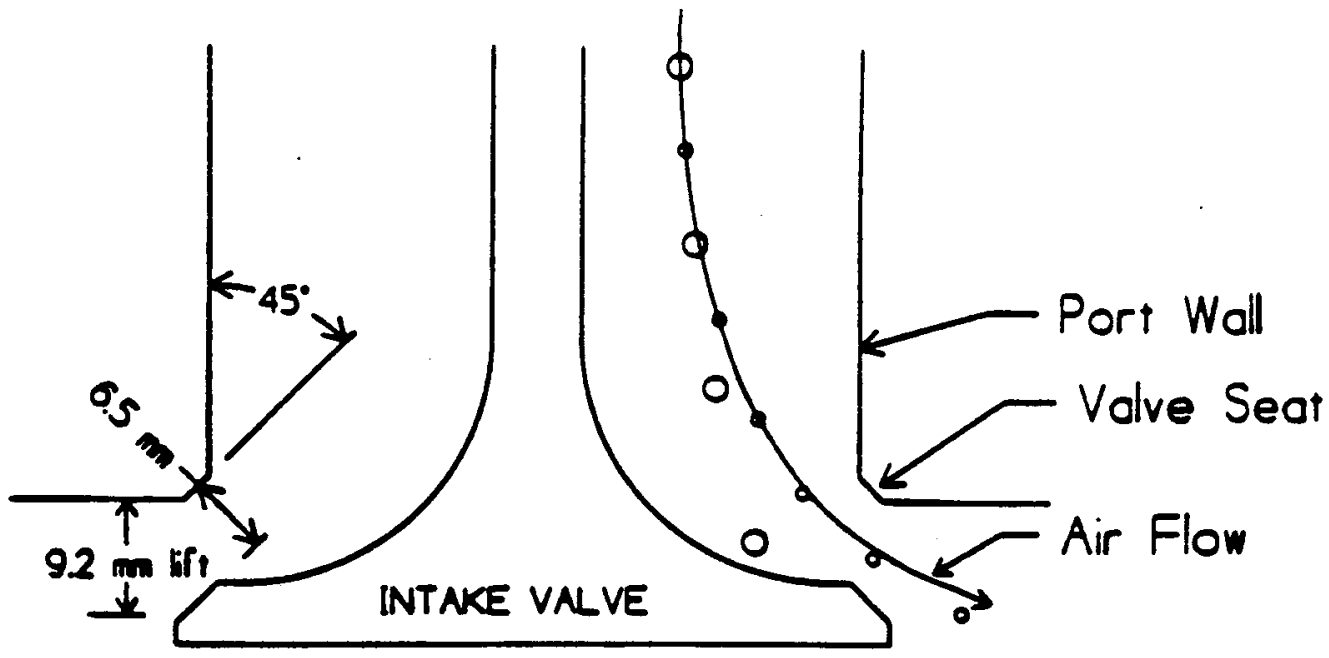

FIGURE 7a. AIR AND FUEL FLOW PAST THE INTAKE VALVE OF TYPICAL ENGINE. SMALL DROPS TURN WITH AIR, WHILE LARGE DROPS CENTRIFUGE OUT.

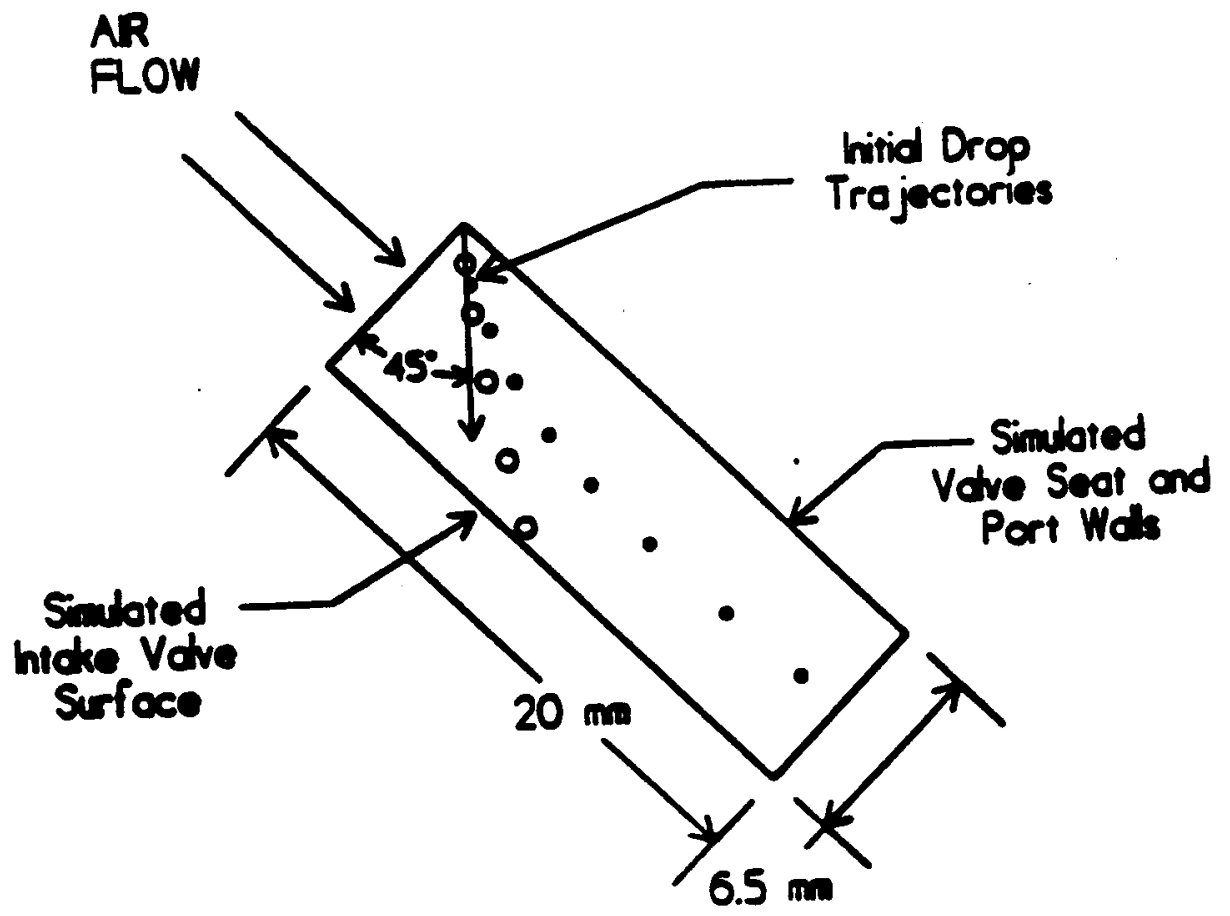

FIGURE 7b. SIMULATION OF AIR AND FUEL FLOW PAST INTAKE VALVE. AIR ASSUMED TO HAVE TURNED $45^{\circ}$ AND DRAG CALCULATIONS PERFORMED WITH TESS TO DETERMINE WHCH DROPS TURN WITH AIR. 

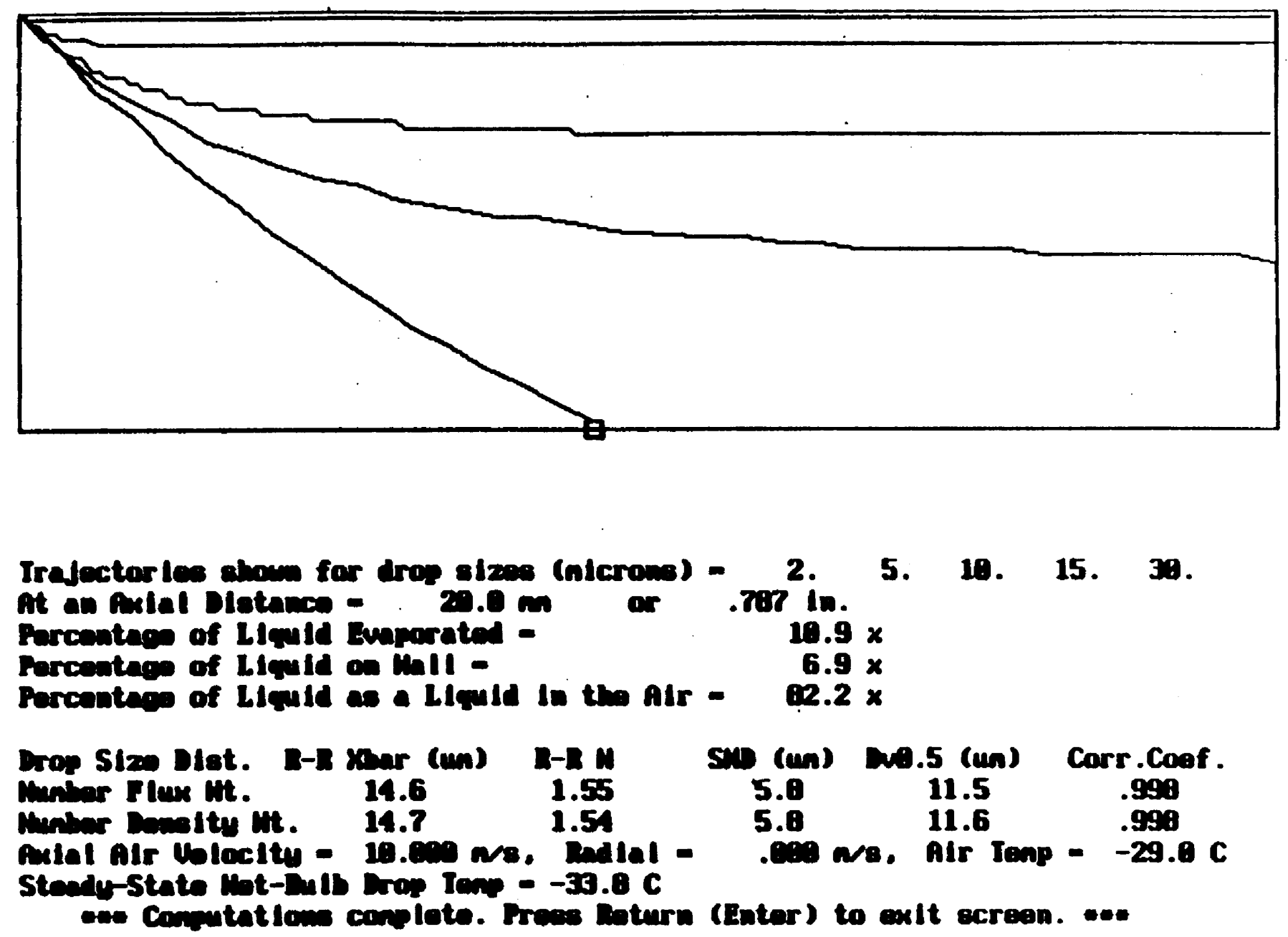

FIGURE 8. COMPUTED DROP TRAJECTORIES FOR FINE-SPRAY INJECTOR FLOW PAST INTAKE VALVE (6.5-mm by 20-mm SECTION), FOR DROP SIZES OF 2 MICROMETERS (AT TOP), 5 MICROMETERS, 10 MICROMETERS, 15 MICROMETERS AND 30 MICROMETERS (AT BOTTOM), REPRESENTING SMALLEST 20\% BY VOLUME SEGMENT OF SPRAY TO LARGEST 20\%, FOR METHANOL SPRAY WITH INITIAL SPRAY CHARACTERISTICS AT INJECTOR TIP OF SMD = 4.5 MICROMETERS AND ROSIN-RAMMLER N PARAMETER OF 1.38, DROP VELOCITY AT INTAKE VALVE OF $13 \mathrm{~m} / \mathrm{s}$, AND AIR VELOCITY (DUE TO INJECTOR AIR JET) OF $10 \mathrm{~m} / \mathrm{s}$ AT INTAKE VALVE. 
valve (or port walls before reaching the valve). Therefore, a goal in fine-spray port fuel injectors is to produce sprays with a significant fraction of the liquid in drops of less than 20 micrometers diameter. Even if fine spray injectors are developed that allow the fuel spray to follow the air stream into the cylinder, then the fuel drops must be evaporated during the compression stroke, or the spark must be of sufficient energy to both vaporize the liquid drops and heat up the fuel-air mixture to combustion temperatures. Calculated in-cylinder evaporation rates are provided below in the section "Estimated InCylinder Evaporation." These calculations show that complete evaporation of fine fuel sprays of ethanol is difficult at cranking conditions.

Under a previous contract for National Renewable Energy Laboratory and the U.S. Department of Energy (NREL/DOE), Southwest Research Institute (SwRI) developed fuel-air mixing caps to place on conventional pintle injectors to convert them into prototype air-assist injectors. These air-assist injectors reduce average particle sizes by roughly an order of magnitude from the standard pintle injectors, but still allow standard pulse width modulation of the fuel flow. However, since the air flow through the injectors is significant relative to total engine air flows, the engine controller must be modified to account for that air flow when operating in open loop mode (that is, when the fuel-air ratio is not set from the oxygen sensor in the exhaust).

The design of the fuel-air mixing cap is shown in Figure 9. Injector caps with three different exit hole diameters, $1.0 \mathrm{~mm}, 1.4 \mathrm{~mm}$, and $2.0 \mathrm{~mm}$, were constructed. The fuel-air mixing cap fitted onto a pintle injector is shown in Figure 10. The atomization performance of all three mixing caps has been determined over a range of atomizing air flows. To simulate spray performance into an intake manifold that varies in air pressure from $1 \mathrm{~atm}$. absolute pressure to about $0.2 \mathrm{~atm}$. absolute, the atomization performance was measured while spraying into a chamber at absolute pressures of $1.0 \mathrm{~atm} ., 0.75 \mathrm{~atm}$. and $0.5 \mathrm{~atm}$. using the facility as shown in Figure 11.

The subatmospheric-pressure atomization facility utilizes an air-ejector to provide relatively low absolute air pressures with a significant amount of air flow through the spray chamber to remove the spray before impacting with the windows of the system. The air flow enters the low-pressure chamber through a valve, and the air turbulence level is then reduced to low levels by passing through a honeycomb flow straightening section with 3-mm (1/8 in.) cell sizes, and then passes through the measurement section and through another valve before entering the air-ejector. The two valves allow independent variation of the chamber pressure and the air velocity.

The atomization results in terms of average drop size were correlated with both differential air pressure and atomizing air mass flow rate. The average drop size was represented by the Sauter mean diameter $\left(\mathrm{SMD}\right.$ or $\mathrm{D}_{32}$ ) defined as:

$$
S M D=D_{32}=\frac{\sum n_{i} D^{3}}{\sum n_{i} D^{2}}
$$

where $n_{i}$ is the number of drop of size $D_{i}$. This is a common representation of average size for drops in combustion applications. The atomizing air pressure differential was the atomizing air pressure minus the chamber air pressure, each expressed in absolute pressure. The atomizing air mass flow was the air flow rate through the air-assist injector.

For the 1.0-mm diameter exit hole, the atomization performance as a function of atomizing air pressure differential is shown in Figure 12 for a 4-ms pulse width, and in Figure 13 for a 10-ms pulse width. 


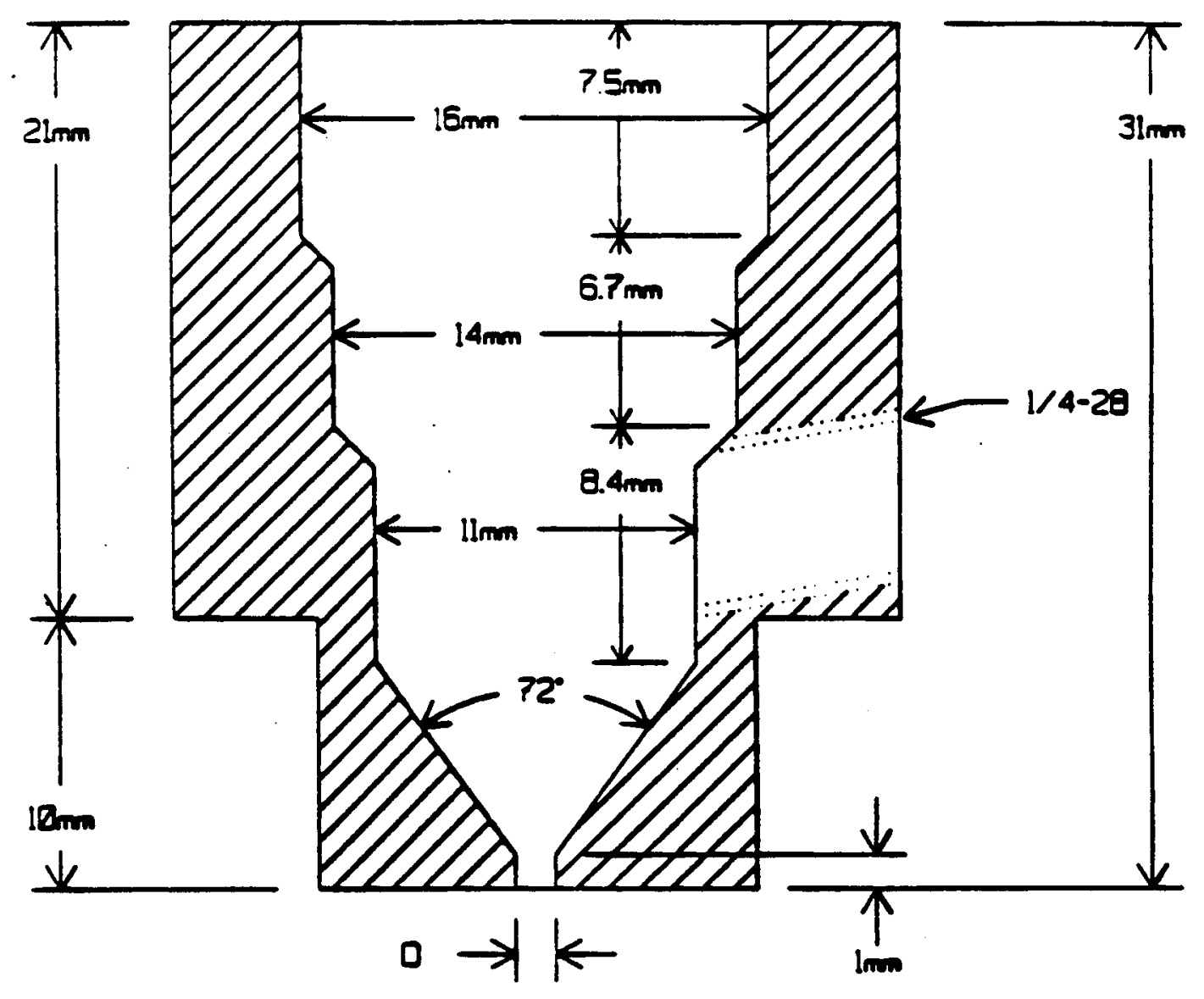

3 INUECTOR CAPS:

$\begin{aligned} D & =1 . D_{\mathrm{mm}} \\ D & =1.4 \mathrm{lmm} \\ \square & =2 . D_{\mathrm{mm}}\end{aligned}$

FIGURE 9. SWRI INTERNAL MIX, AIR-ASSIST INJECTOR CAPS 


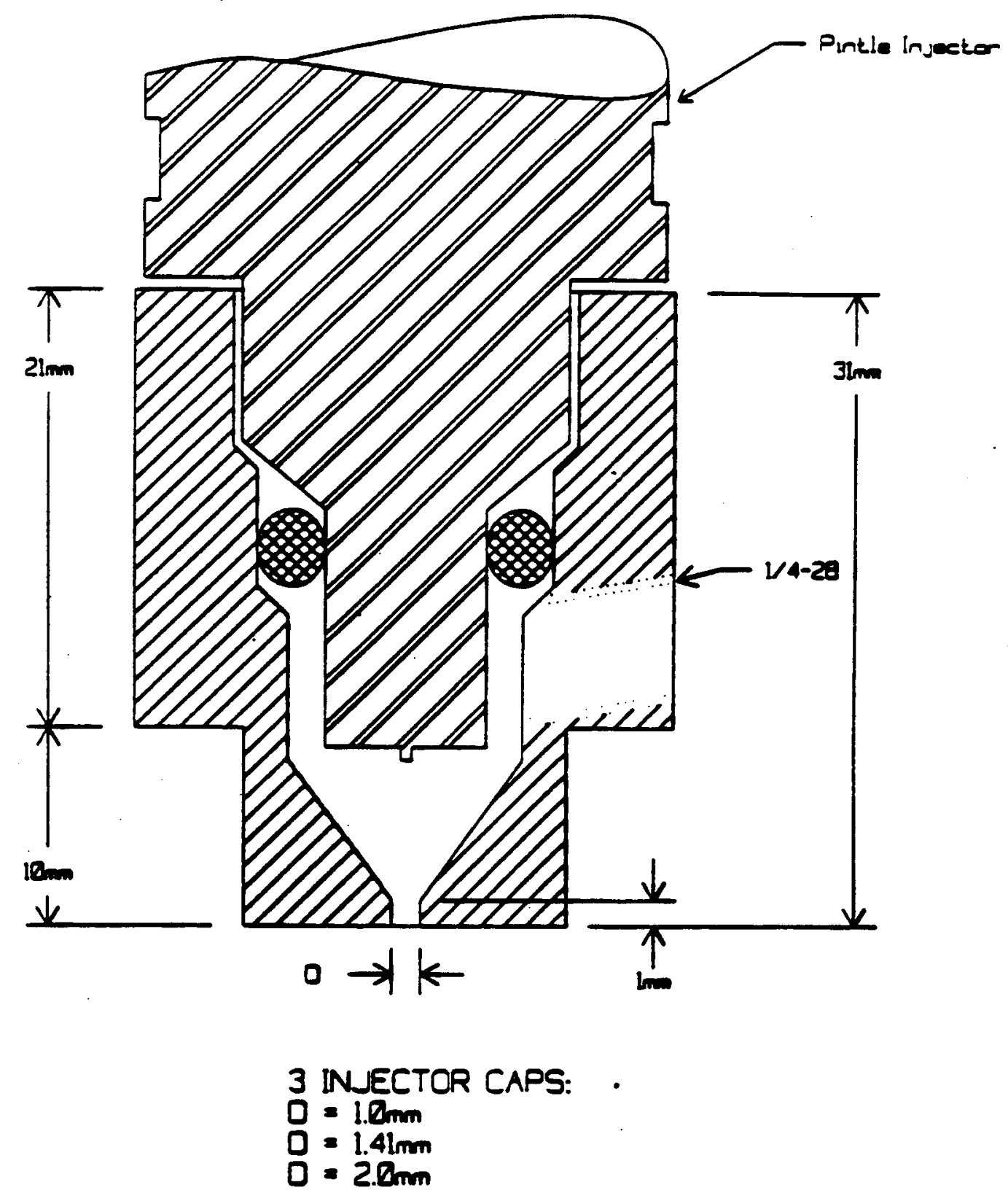

FIGURE 10. SwRI INTERNAL MIX, AIR-ASSIST INJECTOR CAP MOUNTED ON CONVENTIONAL PINTLE INJECTOR 


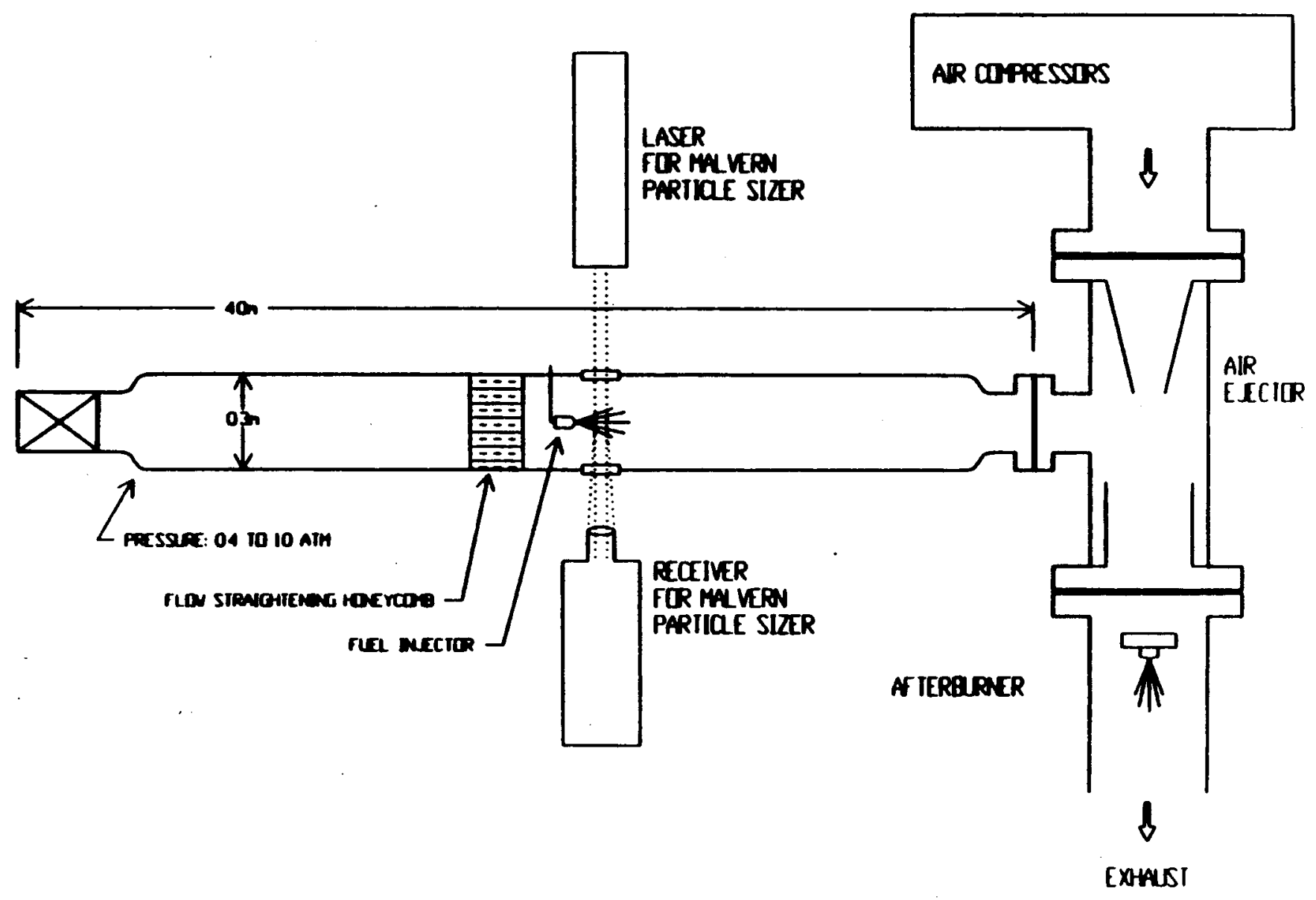

FIGURE 11. SUB-ATMOSPHERIC PRESSURE SPRAY CHARACTERIZATION CHAMBER 


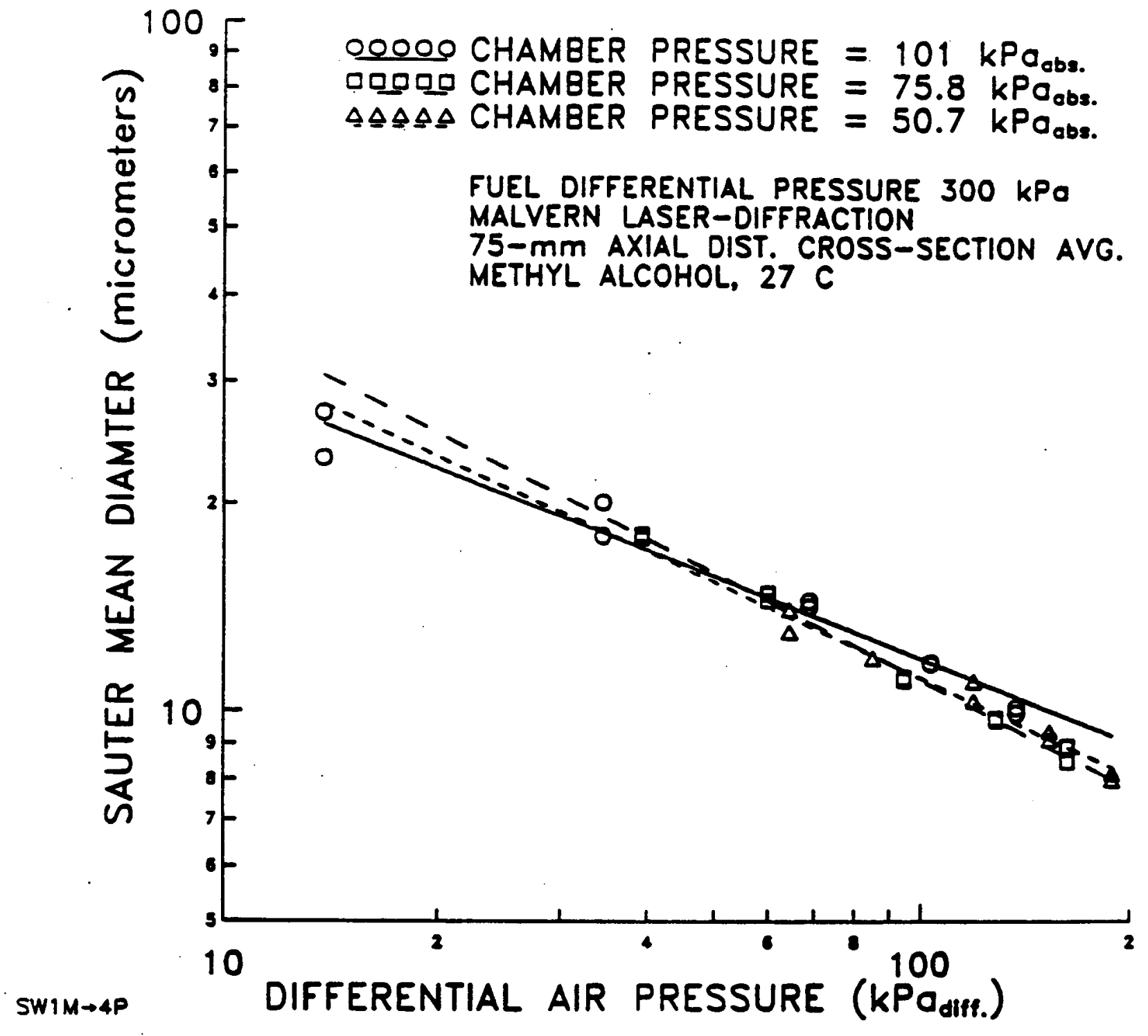

FIGURE 12. ATOMIZATION QUALITY (CROSS-SECTION AVERAGE SMD) VERSUS DIFFERENTIAL AIR PRESSURE FOR SWRI 1.0-mm EXIT-HOLE DIAMETER, INTERNAL-MIX, AIR-ASSIST INJECTOR SPRAYING METHANOL FOR 4-ms PULSE-WIDTH, 50-ms PERIOD. 


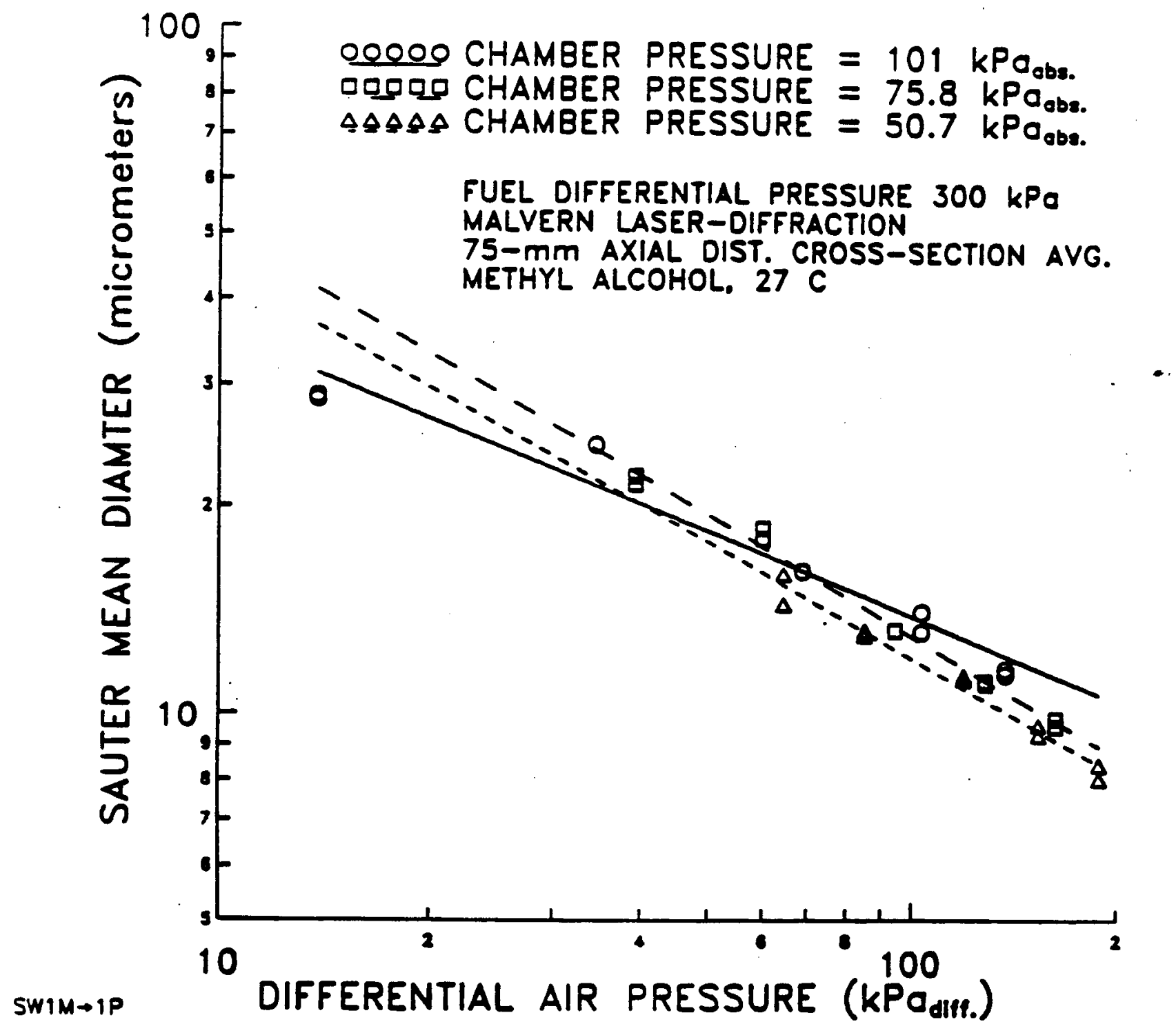

FIGURE 13. ATOMIZATION QUALITY (CROSS-SECTION AVERAGE SMD) VERSUS DIFFERENTIAL AIR PRESSURE FOR SwRI 1.0-mm EXIT-HOLE DIAMETER, INTERNALMIX, AIR-ASSIST INJECTOR SPRAYING METHANOL FOR 10-ms PULSE-WIDTH, 50-ms PERIOD. 
A 4-ms pulse width represents an idle pulse width, and a 10-ms pulse width represents a higher power condition. The same data expressed as a function of atomizing air mass flow rate is shown in Figures 14 and 15. These results show that in spite of the change in air density in the spray chamber (representing the air density in the intake manifold), the spray characteristics are mostly a function of air pressure differential and are almost independent of chamber air density. For a given air mass flow rate, the average drop size decreases with decreasing chamber pressure since the air pressure differential is greater for a given mass flow as the chamber pressure decreases.

Similar data to that reported above for the 1.0-mm exit hole diameter air-assist injector were taken for the injectors with exit hole diameters of 1.4 and $2.0 \mathrm{~mm}$. Trends were similar to that for the $1.0-\mathrm{mm}$ injector. The atomization performance as a function of atomizing air pressure of the three different hole sizes is compared in Figure 16, where all pulse widths were set to $10 \mathrm{~ms}$, and the chamber pressure was atmospheric. For a given differential pressure, the atomization gets better as the hole size increases, but the 1.4-mm and $2.0-\mathrm{mm}$ holes give fairly similar results. Similar results are obtained at 3/4 atmospheres $(75.8 \mathrm{kPa}$ ) absolute chamber pressure, as shown in Figure 17. Of course, the atomizing air mass flow increases dramatically for a given pressure differential, and the higher volumes of high-pressure air adversely affect engine efficiency. The increased air mass flow rate to achieve a given drop size is shown in Figure 18 that compares the three injectors for a pulse width of $10 \mathrm{~ms}$ and a chamber pressure of one atmosphere $(101 \mathrm{kPa})$.

The above data shows that the 1.4-mm hole size meets the requirements of providing significant spray less than 20 micrometers so that a significant portion of the spray may be injected into the cylinder as a spray without requiring vaporization in the port. The 1.4-mm injector cap provides smaller drops than the 1.0 $\mathrm{mm}$ injector cap at an equivalent air pressure, and the $1.4-\mathrm{mm}$ injector cap requires much less air flow than the 2.0-mm injector cap.

\section{Compression Ratio Increase}

The high octane number and latent heat of evaporation for ethanol permits a higher knock-free compression ratio than that of gasoline. Compression ratios listed in the literature for dedicated alcohol (ethanol and methanol) engines in automotive applications range from standard gasoline to 13:1 with an average of 11.01:1. In determining the compression ratio for a ULEV engine, the potential increase in $\mathrm{NO}_{x}$ and hydrocarbon emissions are more of a limiting factor than detonation.

Increasing the compression ratio can be achieved by reducing the cylinder volume at TDC by installing only a domed piston, reducing the combustion chamber volume by machining the cylinder block and head, or a combination of both. The installation of a domed piston is a simple and cost effective means of increasing the compression ratio, but is undesirable as the dome will cause a disruption in the flame propagation and increase the surface-to-area ratio of the combustion volume. $A$ domed piston configuration, compared to a flat face piston, will increase the hydrocarbon-rich quench layer on the piston face and quench volume between the cylinder wall, piston crown, and first compression ring.

J.B. Heywood (1972) in a study of hydrocarbon mass flowrate states that 50 percent of the hydrocarbons in the exhaust escape near the end of the exhaust process due to the exit of a hydrocarbon-rich vortex, and 40 percent escape early in the exhaust process due to the exit of a head quench layer. Changes in the combustion chamber shape and volume may affect the head quench layer.

The original 3.0-liter piston has a flat face and will not inhibit the flame kemel convection which is dominated by the tumble charge motion induced by the squish area of the combustion chamber (Hinze and Cheng, 1993). The velocity of the tumble charge will be increased with a reduced piston to the 


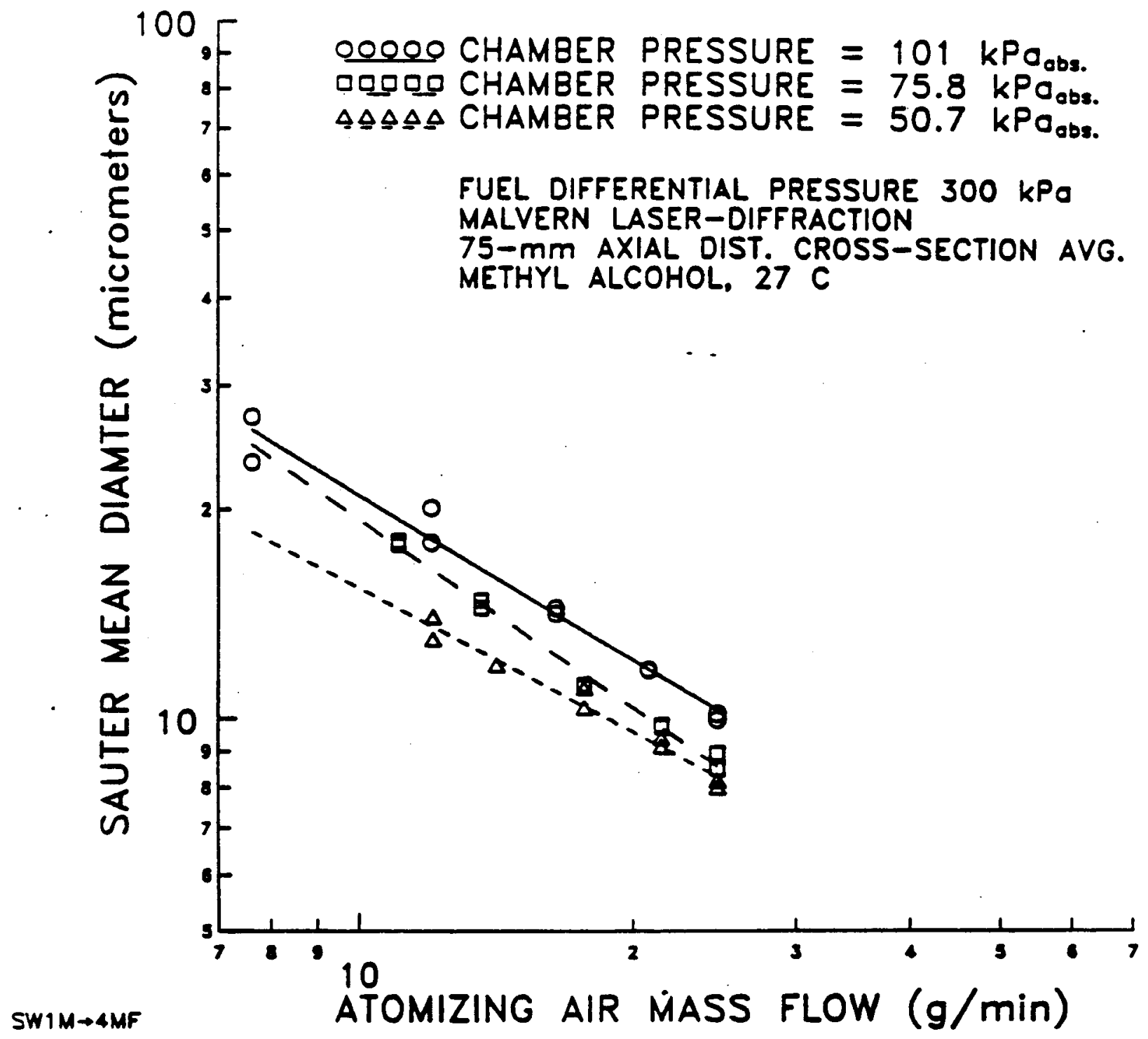

FIGURE 14. ATOMIZATION QUALITY (CROSS-SECTION AVERAGE SMD) VERSUS ATOMIZING AIR FLOW FOR SwRI 1.0mm EXIT HOLE DIAMETER, INTERNAL-MIX, AIR ASSIST INJECTOR SPRAYING METHANOL FOR 4-ms PULSE-WIDTH, 50-ms PERIOD 


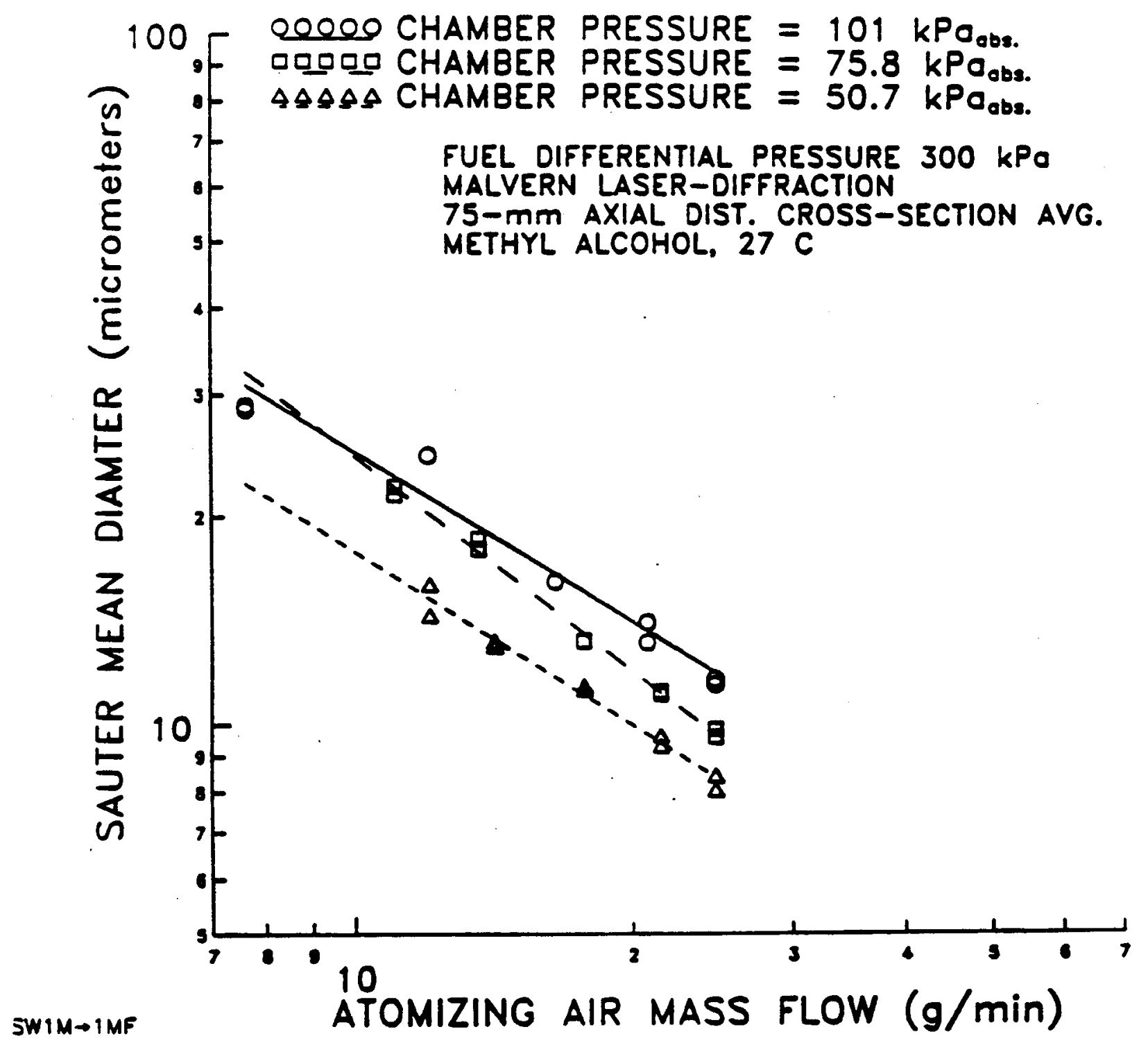

FIGURE 15. ATOMIZATION QUALITY (CROSS-SECTION AVERAGE SMD) VERSUS ATOMIZING AIR FLOW FOR SWRI 1.0-mm EXIT-HOLE DIAMETER, INTERNAL MIX, AIRASSIST INJECTOR SPARYING METHANOL FOR 10-ms PULSE-WIDTH, 50-ms PERIOD 


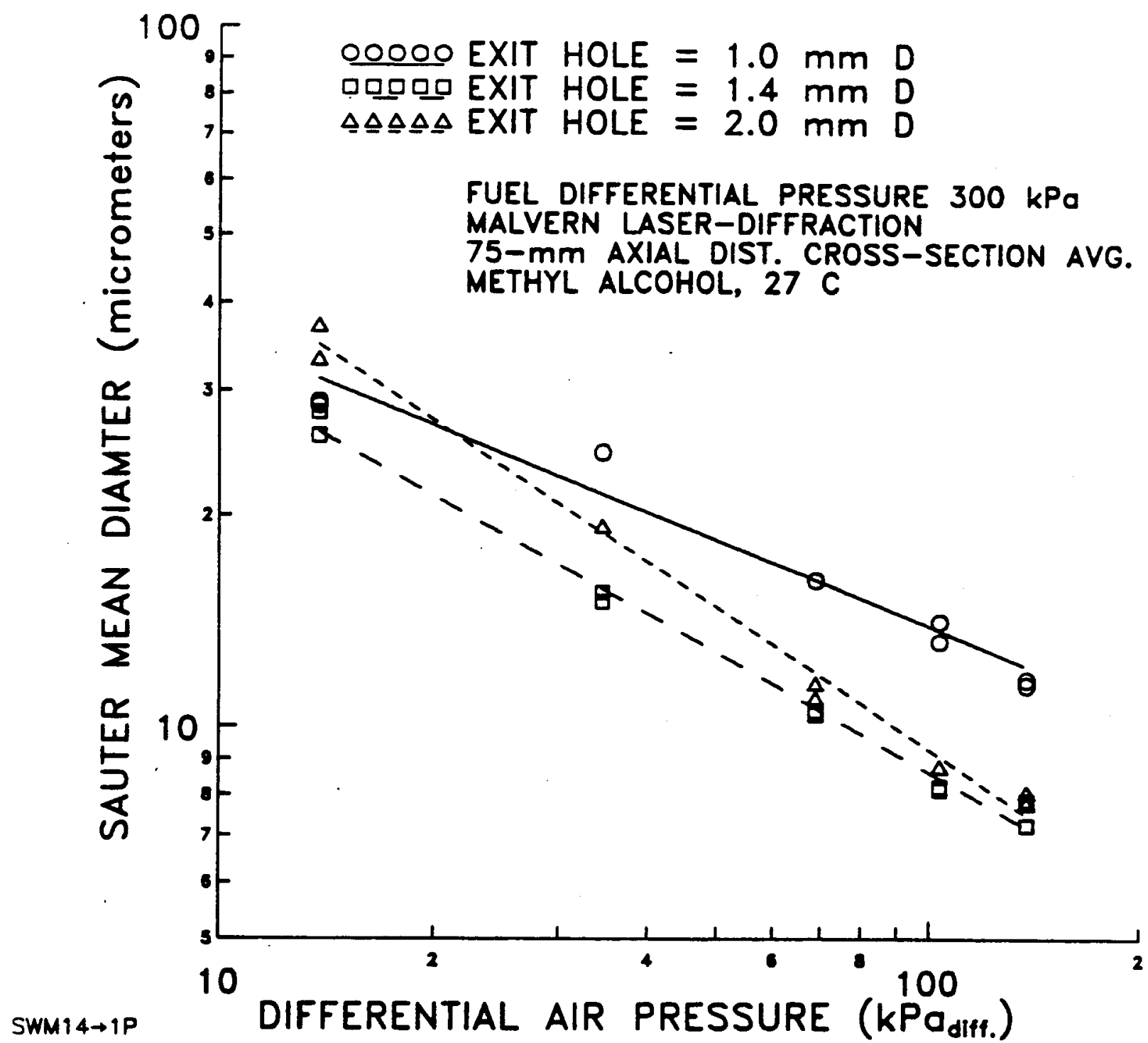

FIGURE 16. EFFECT OF HOLE SIZE ON ATOMIZATION QUALITY (CROSS-SECTION AVERAGE) VERSUS DIFFERENTIAL AIR PRESSURE FOR SWRI SINGLE-HOLE INJECTORS WITH EXIT-HOLE DIAMETERS OF 1.0-,1.4, AND 2.0-mm. METHANOL, 10-ms PULSEWIDTH, 50-ms PERIOD 


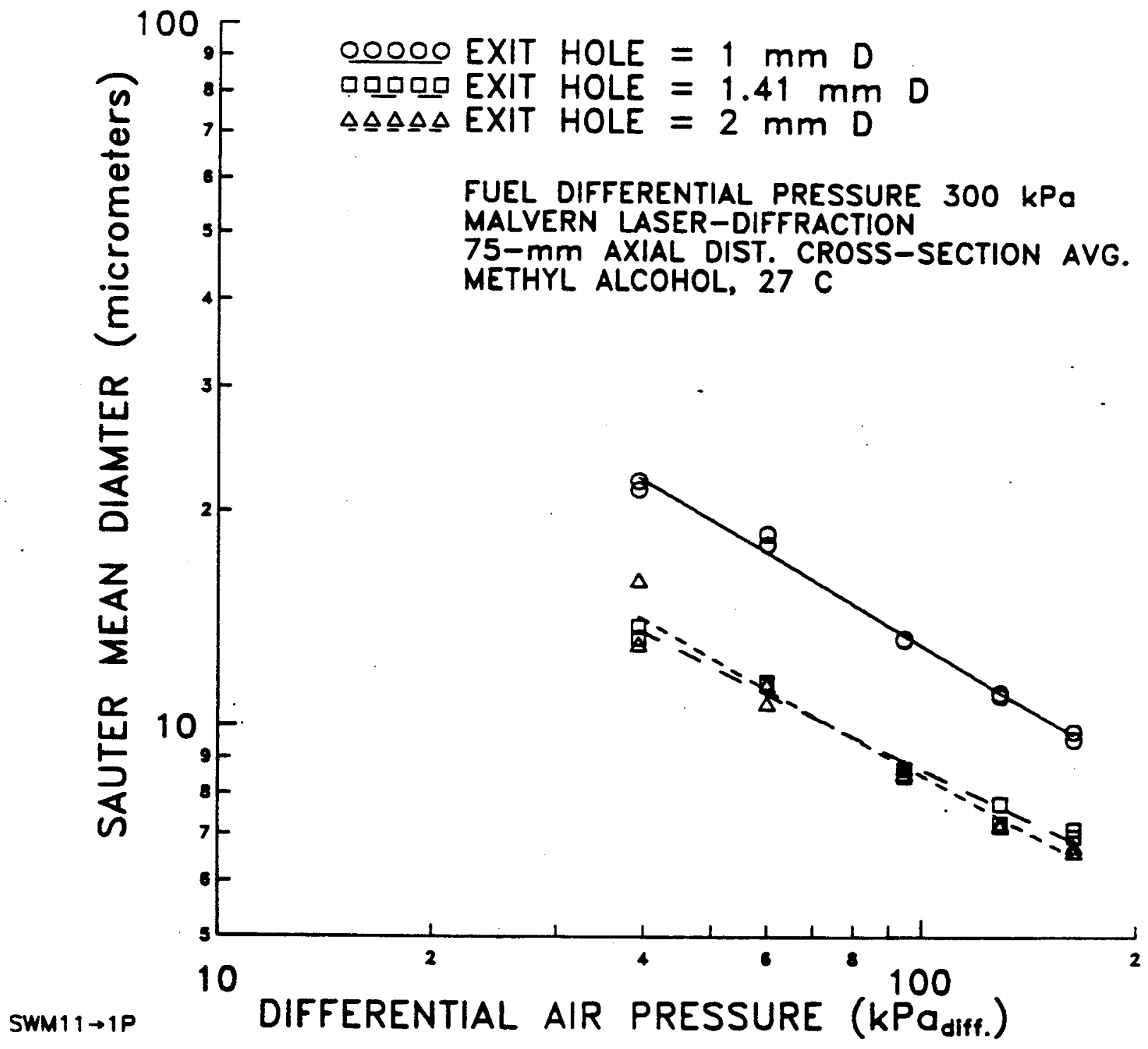

FIGURE 17. COMPARISON OF ATOMIZATION QUALITY (SMDS) VERSUS DIFFERENTIAL AIR PRESSURE FOR THREE INTERNAL-MIX, AIR-ASSIST INJECTORS WTIH EXIT HOLE DIAMETERS OF 1.0-mm, 1.4-mm, and 2-mm EXIT-HOLE DIAMETERS, 10-ms PULSE-WIDTH, SPRAYING INTO CHAMBER AT $75.8 \mathrm{kPa}_{\text {abs }}$. 


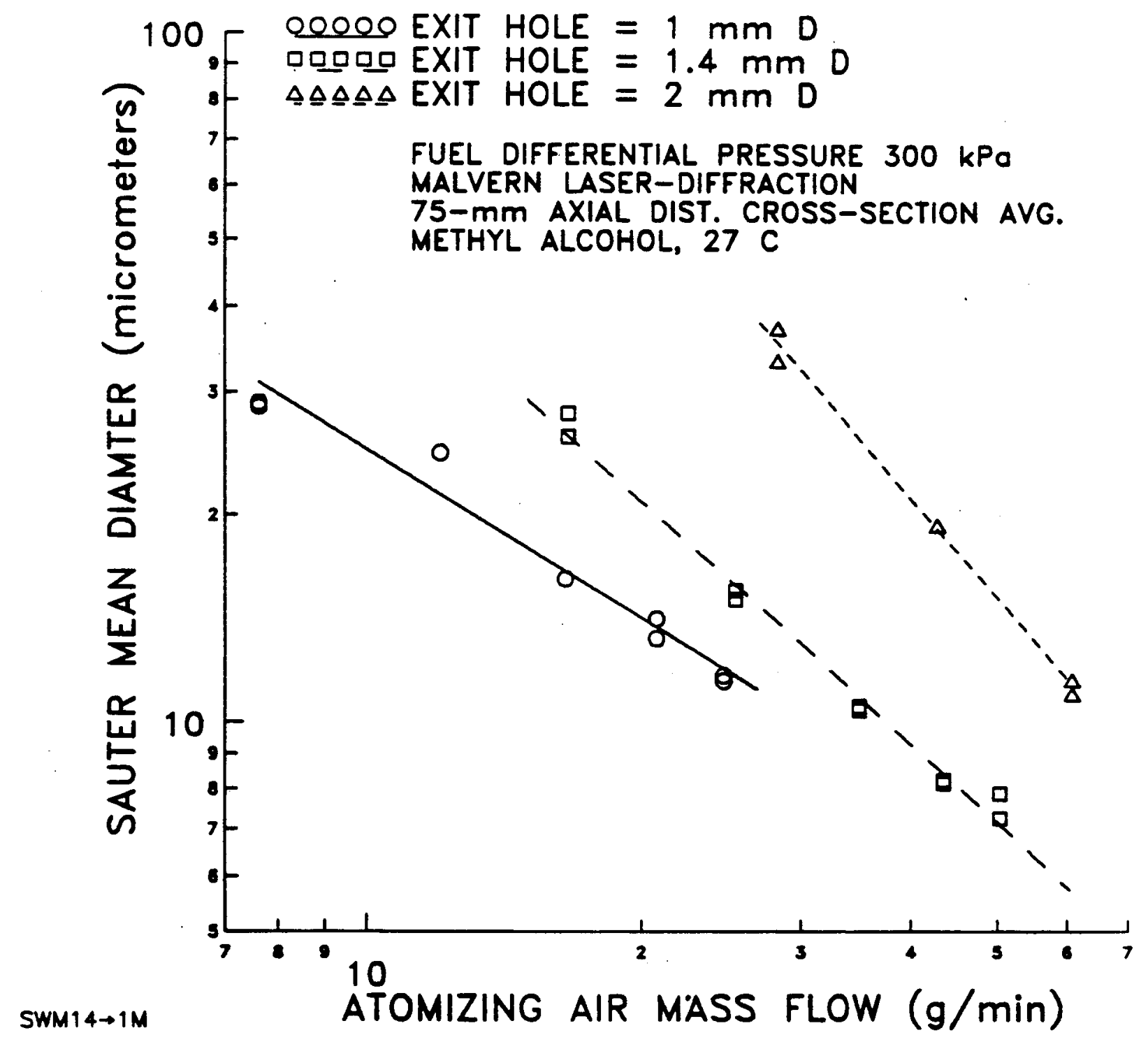

FIGURE 18. EFFECT OF HOLE SIZE ON ATOMIZATION QUALITY (CROSS-SECTION AVERAGE) VERSUS ATOMIZING AIR MASS FLOW FOR SWRI SINGLE-HOLE INJECTORS WITH EXIT-HOLE DIAMETERS OF 1.0, 1.4, and 2.0-mm. METHANOL, 10-ms PULSEWIDTH, 50-ms PERIOD 
cylinder head clearance. Removing the volume between the piston face and cylinder block deck also reduces the quench volume and surface to area ratio. The piston face quench layer and surface area is less on a flat face piston compared to a domed piston design.

Reducing the volume of the cylinder head combustion chamber can be achieved by milling the gasket surface of the head. The thickness to be removed for a specific volume reduction is governed by the geometry of the combustion chamber. A reduced combustion chamber volume will have less of a hydrocarbon-rich head layer.

Figure 19 shows the dimensions of the Ford 3.0-liter reciprocating components and combustion chamber. Table 5 shows the calculations based on these dimensions for increased compression ratios. The piston face-to-block deck clearance is $0.493 \mathrm{~mm}(0.0194 \mathrm{inch})$ which can be reduced by milling the block surface, achieving a zero deck height and removing $3.07 \mathrm{cc}(0.187 \mathrm{ci})$ from the clearance volume. The original cylinder head combustion chamber volume was measured to be $49.6 \mathrm{cc}$ ( $3.03 \mathrm{ci}$ ) and Table 5 gives compression ratios corresponding to volume removed from the chamber. Calculations were performed for reducing the clearance volume by machining the cylinder head and block gasket surfaces the maximum safe amount. Valve-to-cylinder block interference will occur if the head is machined too great an extent and potential cylinder head failure will exist. The calculations are approximate as the volume of reliefs cut into the cylinder bore to eliminate shrouding the valves were not accounted for.

TABLE 5. FORD 3.0-LITER FFV - CYLINDER MODIFICATIONS

\begin{tabular}{||l|c|l|c|}
\hline \multicolumn{2}{|c|}{ Original Dimensions } & \multicolumn{2}{c|}{ Modified Dimensions } \\
\hline \hline Combustion Chamber Volume & $48.56 \mathrm{cc}$ & $\begin{array}{l}\text { Mill Head 0.71 mm }(0.028 \\
\text { in) }\end{array}$ & $45.06 \mathrm{cc}$ \\
\hline Head Gasket Volume & $7.69 \mathrm{cc}$ & & $7.69 \mathrm{cc}$ \\
\hline Piston-to-Deck Volume & $3.07 \mathrm{cc}$ & $\begin{array}{l}\text { Mill Block } 0.49 \mathrm{~mm}(0.019 \\
\text { in) }\end{array}$ & $0 \mathrm{cc}$ \\
\hline Ring Crevice Volume & $0.58 \mathrm{cc}$ & & $0.58 \mathrm{cc}$ \\
\hline Valve Relief Volume & $0.34 \mathrm{cc}$ & & $0.34 \mathrm{cc}$ \\
\hline Piston Dome Volume & $0 \mathrm{cc}$ & $1.01 \mathrm{~mm}(0.040 \mathrm{in})$ height & $-4.0 \mathrm{cc}$ \\
\hline $\begin{array}{l}\text { Clearance Volume } \\
\text { Swept Volume }\end{array}$ & $60.24 \mathrm{cc}$ & & $47.42 \mathrm{cc}$ \\
\hline Compression Ratio & $498.13 \mathrm{cc}$ & & $498.13 \mathrm{cc}$ \\
\hline
\end{tabular}

A maximum compression ratio of approximately $10.4: 1$ can be achieved by the machining procedures alone. The target compression ratio of $11: 1 \mathrm{can}$ be achieved by the addition of pistons with a small dome volume of $4.0 \mathrm{cc}(0.244 \mathrm{ci})$. The combination of cylinder head and block machining and pistons with a very small dome will achieve the desired compression ratio for increased engine efficiency while minimizing the quench volume. 
$1.245 \mathrm{~mm}$ (0.049 in) head gasket (crushed)

\subsection{V-6 FFV} cylinder dimensions

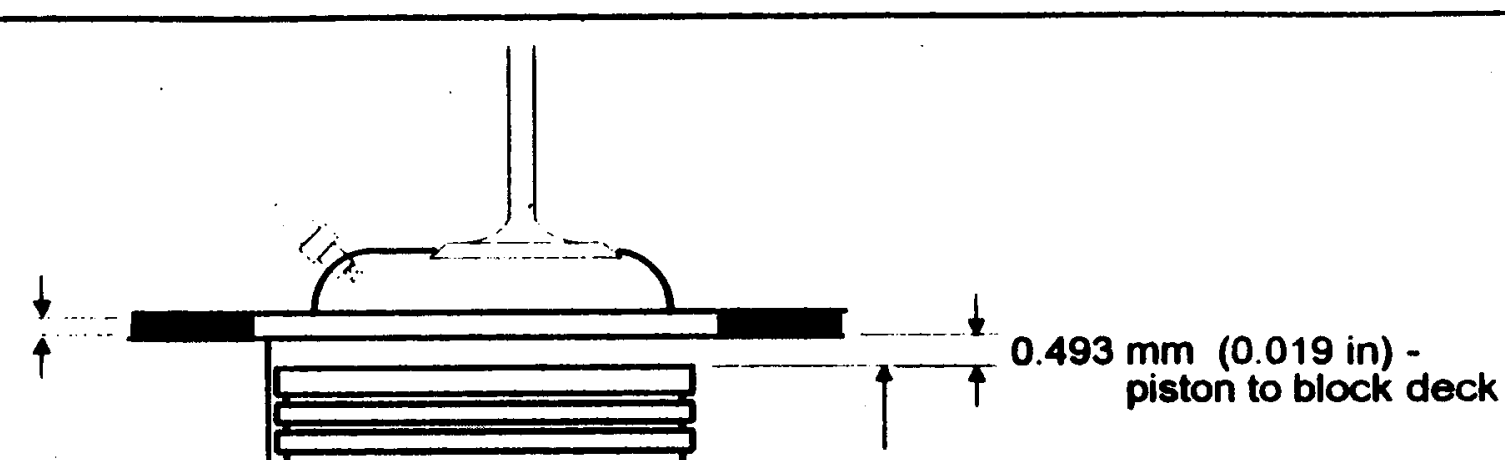

$38.997 \mathrm{~mm}$ (1.535 in) piston compression height

$140.50 \mathrm{~mm}(5.532 \mathrm{in})$ connecting rod

$40.0 \mathrm{~mm}$ (1.575 in) - stroke / 2
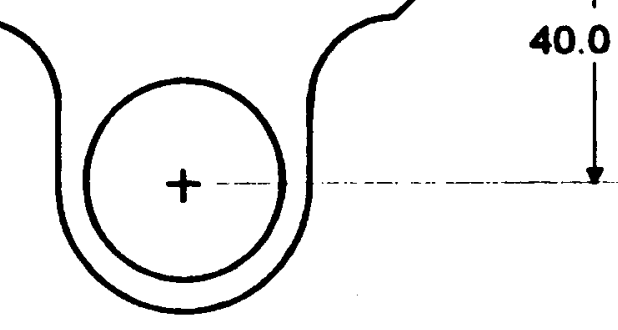

FIGURE 19. PISTON AND COMBUSTION CHAMBER FOR FORD TAURUS 3.0-LITER V-6 


\section{Estimated In-Cylinder Evaporation}

The evaporation of the fine-spray ethanol fuels in-cylinder, including the effect of compression ratio increases, has been analyzed using the TESS code interfaced with a reciprocating engine cycle simulation computer code. The standard TESS code is a dilute spray model that assumes that the liquid phase is affected by the gas phase, but that the gas phase is not affected the liquid phase. For example, it is assumed that the air density results in drag on the drops and changes their momentum, but the drops do not change the momentum of air. However, when interfaced with the cycle simulation, some dense spray effects are included. The heat required to vaporize the liquid fuel drops is taken (computationally) from the air, reducing the in-cylinder air temperature. Likewise, the build-up of fuel vapor in-cylinder reduces the evaporation rate. The specific heat of the gases is adjusted to account for the fuel vapor, affecting compression temperatures.

The engine chosen for these simulations was the Ford 3.0-liter engine (9.3 compression ratio) used in the flexible fuel vehicle (FFV), since that is the vehicle to be modified as a dedicated ethanol-blend fueled ULEV in the conduct of this project. Some of the engine specifications are given in Table 6 . Calculations were performed for two fuels, neat ethanol and n-heptane, which was used as a single-component approximation to gasoline. Evaporation of multi-component fuels cannot be accurately predicted from calculations of single-component approximations, but approximate trends may be illustrated. Some of the fuel specifications are given in Table 7. Note that the mass of ethanol that must be injected per unit mass of fuel is about 1.63 times that of gasoline, and since the lower heating value for a stoichiometric mixture of ethanol and air is about 5 percent lower than gasoline-air, then an equivalent power requires about 1.71 times as much ethanol as gasoline.

TABLE 6. SPECIFICATIONS OF FORD TAURUS 3.0-LITER ENGINE

\begin{tabular}{|c|c|}
\hline Bore & $89 \mathrm{~mm}$ \\
\hline Stroke & $80 \mathrm{~mm}$ \\
\hline Rod Length & $140 \mathrm{~mm}$ \\
\hline Compression Ratio & 9.3 \\
\hline Cylinders & 6 \\
\hline Cycles & 4 \\
\hline Swirl No. & 0.3 \\
\hline Intake Valve Opening & 698.5 \\
\hline Intake Valve Closing & 252.5 \\
\hline Exhaust Valve Opening & 469.5 \\
\hline Exhaust Valve Closing & 23.5 \\
\hline
\end{tabular}


TABLE 7. FUEL PROPERTIES FOR IN-CYLINDER EVAPORATION CALCULATIONS

\begin{tabular}{|c|c|c|c|c||}
\hline \hline Fuel & $\begin{array}{c}\text { Boiling Point } \\
\text { (C) }\end{array}$ & $\begin{array}{c}\text { Latent Heat of } \\
\text { Vaporization } \\
\text { (kJ/kg) }\end{array}$ & $\begin{array}{c}\text { Molecular } \\
\text { Weight }\end{array}$ & $\begin{array}{c}\text { Air/Fuel, } \\
\text { Stoichiomet } \\
\text { ric (Dry } \\
\text { air) }\end{array}$ \\
\hline \hline n-Heptane & 98.4 & 317.8 & 100.2 & 15.21 \\
\hline Califomia Phase II Gasoline & 96. & 350. & & $\approx 14.6$ \\
\hline Ethanol & 78.3 & 962.6 & 46.1 & 9.01 \\
\hline
\end{tabular}

In-cylinder evaporation calculations were made for cold-start conditions of air and engine coolant temperatures of $-25^{\circ} \mathrm{C}\left(-13^{\circ} \mathrm{F}\right), 0^{\circ} \mathrm{C}\left(32^{\circ} \mathrm{F}\right)$, and $25^{\circ} \mathrm{C}\left(77^{\circ} \mathrm{F}\right)$. Some parametric studies were performed for the $0^{\circ} \mathrm{C}$ condition. Cranking speeds were assumed to be $120 \mathrm{rpm}$ at $-25^{\circ} \mathrm{C}, 170 \mathrm{rpm}$ at $0^{\circ} \mathrm{C}$, and 250 rpm at $25^{\circ} \mathrm{C}$. The computations were for these cranking conditions, and assumed intake and exhaust pressures of $100 \mathrm{kPa}_{\text {absolute }}$ (14.6 psia). Cranking is of particular interest for ULEV vehicles because a few misfires or lack of complete burns during cranking produces enough unburned fuel that the vehicle will not pass ULEV emissions standards. All calculations assumed that the fuel enters the cylinder at 90 crank angle degrees (CAD) from TDC on the intake stroke, or when the piston is half way down on the intake stroke. (TDC firing is $360^{\circ} \mathrm{CA}$.) The spray was assumed to enter the cylinder as a fine liquid spray with an SMD of $10 \mu \mathrm{m}$ and a Rosin-Rammler distribution width parameter of 1.5 , with no vaporization. For these fine sprays, the fuel quickly began evaporation and reached equilibrium with the surroundings during the intake stroke, cooling the air and saturating it with fuel vapor, stopping further evaporation, especially for the ethanol fuels. Therefore, including the vaporization in the port did not change the incylinder results.

Figures 20 through 22 show the evaporated fuel fraction during cranking for $\mathrm{n}$-heptane, representing the mid-point of gasoline and neat ethanol for air and engine temperatures of $25^{\circ} \mathrm{C}\left(77^{\circ} \mathrm{F}\right), 0^{\circ} \mathrm{C}\left(32^{\circ} \mathrm{F}\right)$, and $-25^{\circ} \mathrm{C}\left(-13^{\circ} \mathrm{F}\right)$, respectively. Note that for the mid-point of gasoline simulated by n-heptane, evaporation is complete or close to completion before TDC, while in no case is ethanol completely evaporated by TDC. Since the amount of fuel injected was for a stoichiometric mixture in the cylinder, the n-heptane vaporizes in the cylinder to a flammable vapor-air mixture for all cases. Since the lean limit for combustion is about 60 percent of stoichiometric, the ethanol vaporizes in the cylinder to above the lean limit for these conditions, but once the engine begins firing and the speed increases, there is probably not sufficient time for vaporization above the flammability limit.

Thus, under cold-start conditions for the neat ethanol fuel, vaporization of a flammable vapor-air mixture prior to ignition is difficult or impossible, even if the spray can be injected directly into the cylinder. Contrast this with the fact that Siewert and Groff (1987) demonstrated successful starts with neat methanol (M100) at $-29^{\circ} \mathrm{C}\left(-20^{\circ} \mathrm{F}\right)$ using a direct-injected engine. The compression ratio of that engine was 13:1 rather than the 9.3:1 for this 3-liter engine, but the calculations of compression heating for that engine again show that a combustible vaporized mixture cannot be generated in the short time available for a direct-injected fuel spray. Therefore, it was postulated by Jorgensen (1988) that combustion occurred when the spark energy was used to both vaporize the liquid fuel drops and then heat the fuel-air mixture up to combustion temperatures. This is the same mechanism used to start gas turbine engines that use very non-volatile fuels at low temperatures. This is feasible if the fuel spray can be maintained in the air 
rather than being deposited on the walls of the combustion chamber. It is more difficult to keep the portinjected spray off the walls than the direct-injected spray because the port-injected spray must stay suspended through both the intake and compression strokes, while the direct-injected spray must stay suspended for only 10 or $20 \mathrm{CAD}$.

The ethanol fuel evaporates more slowly than gasoline (n-heptane in this simulation) because of its high heat of vaporization, as shown in Table 7. The boiling point of the ethanol is actually lower than the $n$ heptane, as shown in Table 7. The fuel evaporation cools the air rapidly for these fine spray injectors, as shown in Figure 23 for the $25^{\circ} \mathrm{C}$ condition and in Figure 24 for the $0^{\circ} \mathrm{C}$ condition. Ethanol cools the air much more than $n$-heptane.

The model can also be used to evaluate hydrocarbon levels expected in-cylinder, and these values could be compared with measurements by a fast-response hydrocarbon analyzer. Figure 25 shows predicted hydrocarbon levels for the $0^{\circ} \mathrm{C}$ case expressed as parts per million carbon (ppmC). Stoichiometric mixtures are about $127,000 \mathrm{ppmC}$, and lean limits are about 60 percent of that value. There are some interesting differences in the controlling mechanisms for the evaporation rates for these fine sprays for the different fuels. For the n-heptane, even these fine sprays are limited in evaporation rate by the mass transfer rate of the fuel from the drop surface. This is illustrated in Figure 26 that shows the saturation fuel partial pressure at the drop surface compared with the free-stream fuel partial pressure for the $0^{\circ} \mathrm{C}$ cranking condition. The difference between these values is the driving force for evaporation at every crank angle. As soon as the fuel is injected at $90 \mathrm{CAD}$, the air cools and is saturated with fuel vapor, so there is very little driving force for evaporation between about 100 and $250 \mathrm{CAD}$, but after $250 \mathrm{CAD}$ the air temperature is rising due to compression heating, and the driving force for evaporation is large.

Contrast Figure 26 with Figure 27 for the same cranking condition but for ethanol. For the ethanol spray shown in Figure 27, there is again saturation between about 100 and $250 \mathrm{CAD}$, but beyond $250 \mathrm{CAD}$ the difference between the fuel vapor pressure at the surface of the drop (wet-bulb saturation pressure) and in the bulk cylinder gases is much less than for $n$-heptane, and therefore, the driving force for evaporation is much less.

The wet-bulb saturation vapor pressure is lower for the ethanol than for $n$-heptane because the larger latent heat of vaporization for ethanol cools both the liquid drops and the air more than for the $n$-heptane. Even more significantly, the bulk in-cylinder vapor concentrations are much higher for ethanol than for $n$ heptane for two reasons. First, when a given mass of the ethanol fuel makes the transition from liquid to vapor, it creates many more moles of gas due to the lighter molecular weight of the ethanol. Secondly, because of the lower air/fuel ratios for stoichiometric combustion for ethanol (as shown in Table 7), a greater mass of ethanol fuel must be injected.

The differences shown in Figures 26 and 27 have some very important practical implications. First, for these very fine ethanol sprays, the evaporation at these conditions is not limited very much by mass transfer rates from the drops. Therefore, making the ethanol spray finer than the $10 \mu \mathrm{m} \mathrm{SMD} \mathrm{used} \mathrm{in} \mathrm{the}$ calculations will not enhance the amount of fuel evaporated very significantly. However, sprays with drop sizes larger than about $10 \mu \mathrm{m}$ SMDs will be limited by drop mass transfer rates, and larger drop-size sprays will therefore evaporate more slowly. Another implication of these results is that enrichment to help in cold-starting will be effective for $n$-heptane in raising the vaporized fuel concentration in the cylinder, while it will be only slightly helpful for the ethanol.

To prove this last point, calculations at the $0^{\circ} \mathrm{C}$ condition were repeated with twice the stoichiometric amount of fuel injected, with predicted hydrocarbon concentrations as shown in Figures 28 and 29 for $\mathrm{n}$-heptane and ethanol, respectively. The concentration of $\mathrm{n}$-heptane in-cylinder is greatly increased by 


$$
\begin{aligned}
& \text { IN-CYLINDER EVAPORATION } \\
& 3-\text { Liter Ford, } 250 \text { rPm, } 25 \mathrm{C} \\
& \text { SMD }=10 \mu \mathrm{m}, \phi=1.0, \quad C R=9.3
\end{aligned}
$$

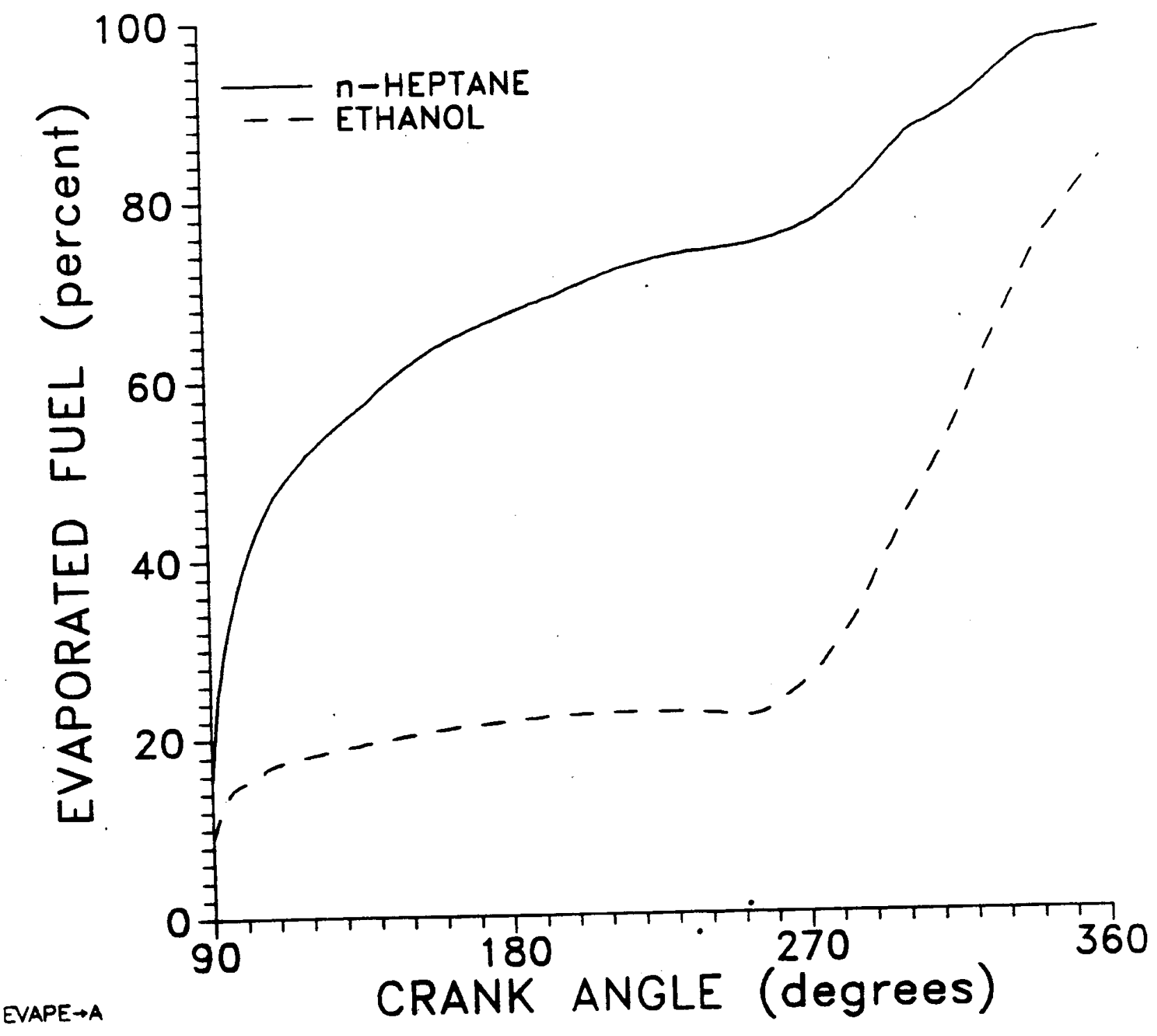

FIGURE 20. COMPUTED IN-CYLINDER EVAPORATION FOR GASOLINE (N-HEPTANE) AND NEAT ETHANOL FUEL SPRAY WITH SMD=10 MICROMETERS (ROSIN-RAMMLER $N=1.5$ ) IN FORD TAURUS 3.0-LITER V-6 CRANKING AT 250 rpm, 25 DEGREES C AIR AND ENGINE 


$$
\begin{aligned}
& \text { IN-CYLINDER EVAPORATION } \\
& 3-\text { Liter Ford, } 170 \mathrm{rPm}, 0 \mathrm{C} \\
& \text { SMD }=10 \mu \mathrm{m}, \phi=1.0, \quad C R=9.3
\end{aligned}
$$

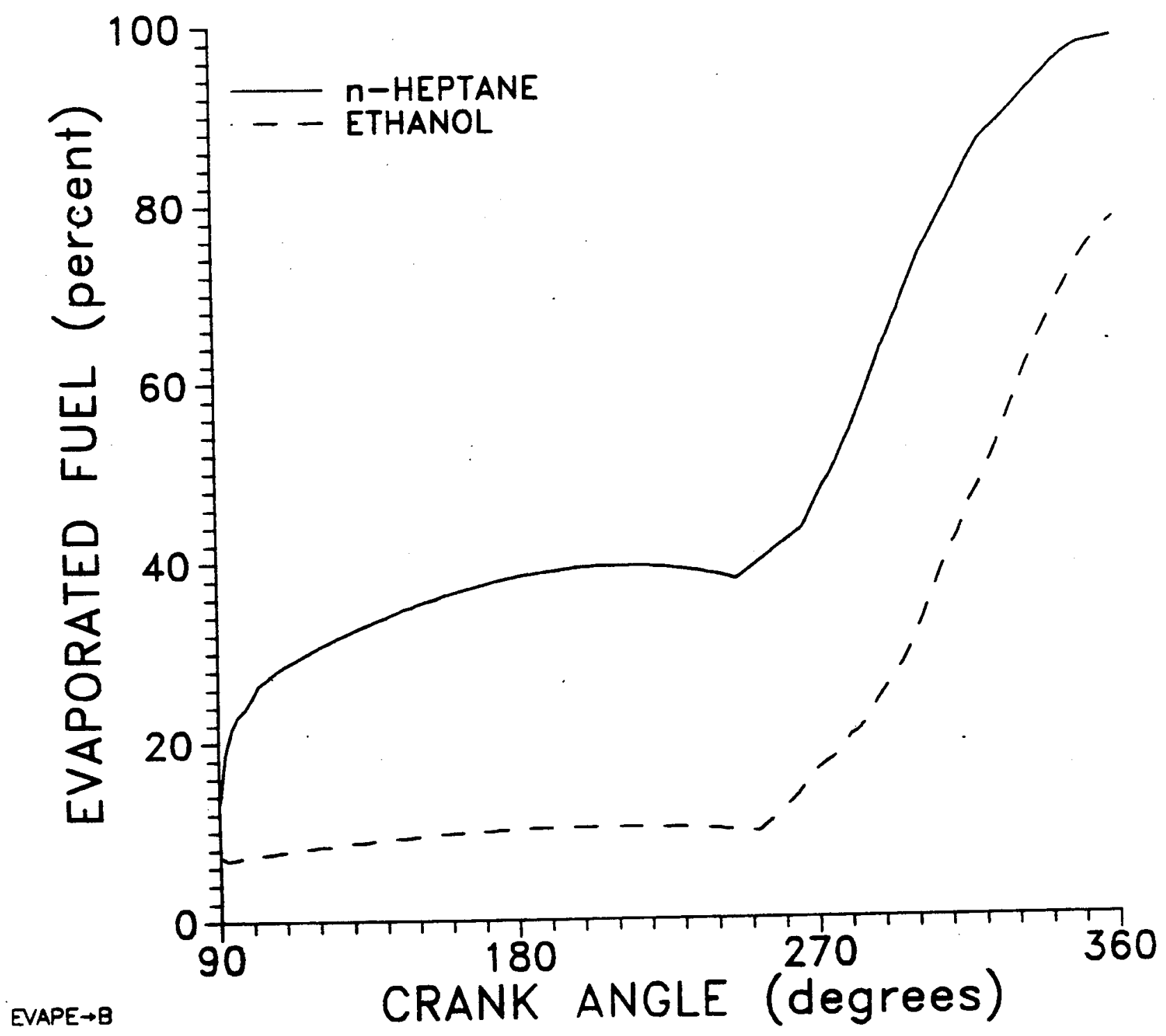

FIGURE 21. COMPUTED IN-CYLINDER EVAPORATION FOR GASOLINE (N-HEPTANE) AND NEAT ETHANOL FUEL SPRAY WITH SMD=10 MUCROMETERS (Rosin-Rammler $N=1.5$ ) IN FORD TAURUS 3.0-LITER V-6 CRANKING AT 170 rpm, 0 DEGREES C AIR AND ENGINE 


\section{IN-CYLINDER EVAPORATION 3-Liter Ford, $120 \mathrm{rpm},-25 \mathrm{C}$ $S M D=10 \mu \mathrm{m}, \quad \phi=1.0, \quad C R=9.3$}

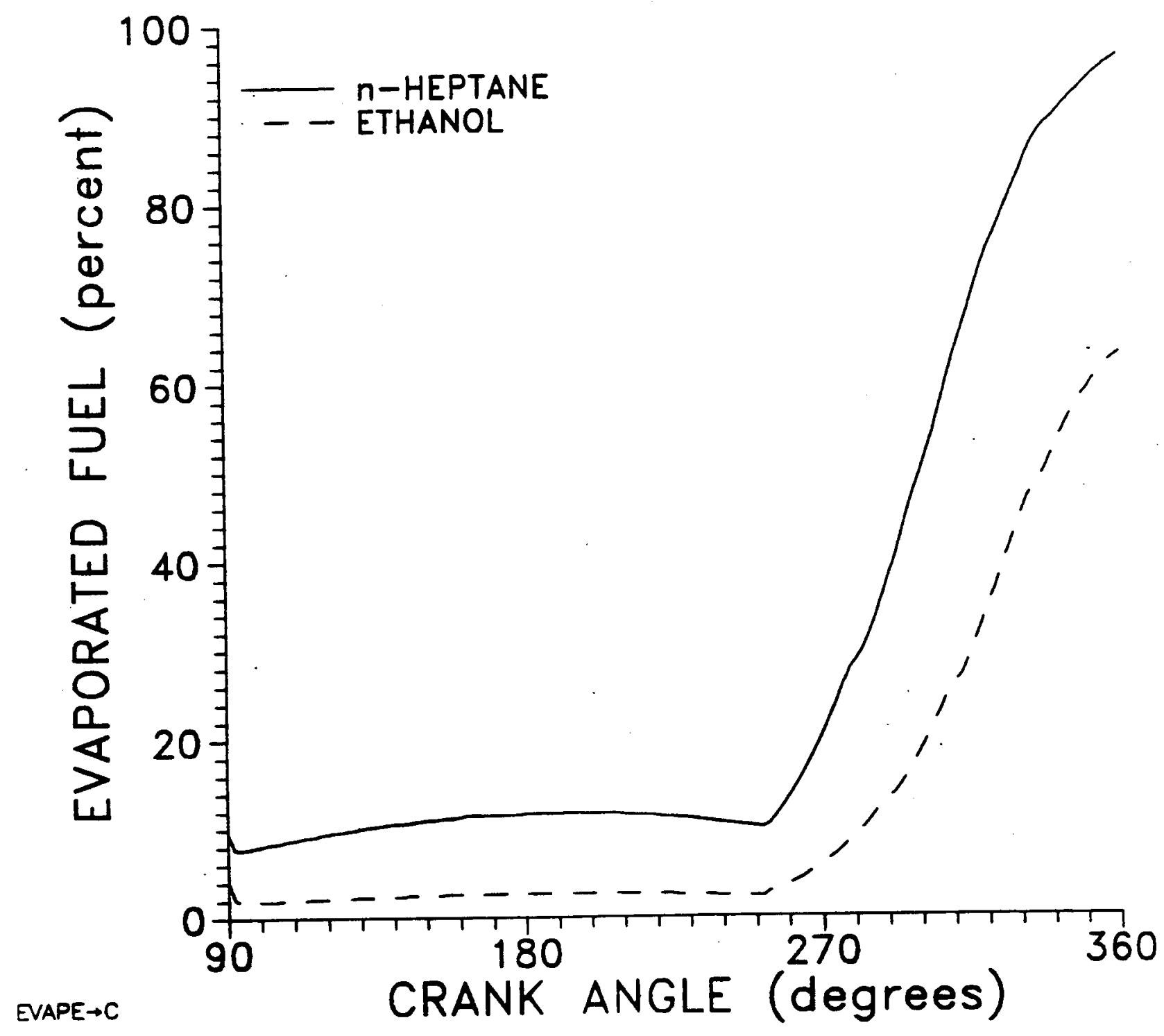

FIGURE 22. COMPUTED IN-CYLINDER EVAPORATION FOR GASOLINE (N-HEPTANE) AND NEAT ETHANOL FUEL SPRAY WITH SMD $=10$ MICROMETERS (ROSIN-RAMMLER N=1.5) IN FORD TAURUS 3.0-LITER V-6 CRANKING AT 120 rpm, -25 DEGREES C AIR AND ENGINE 


\section{BULK GAS TEMPERATURE \\ 3-Liter Ford, $250 \mathrm{rpm}, 25 \mathrm{C}$ $\mathrm{SMD}=10 \mu \mathrm{m}, \quad \phi=1.0, \quad \mathrm{CR}=9.3$}

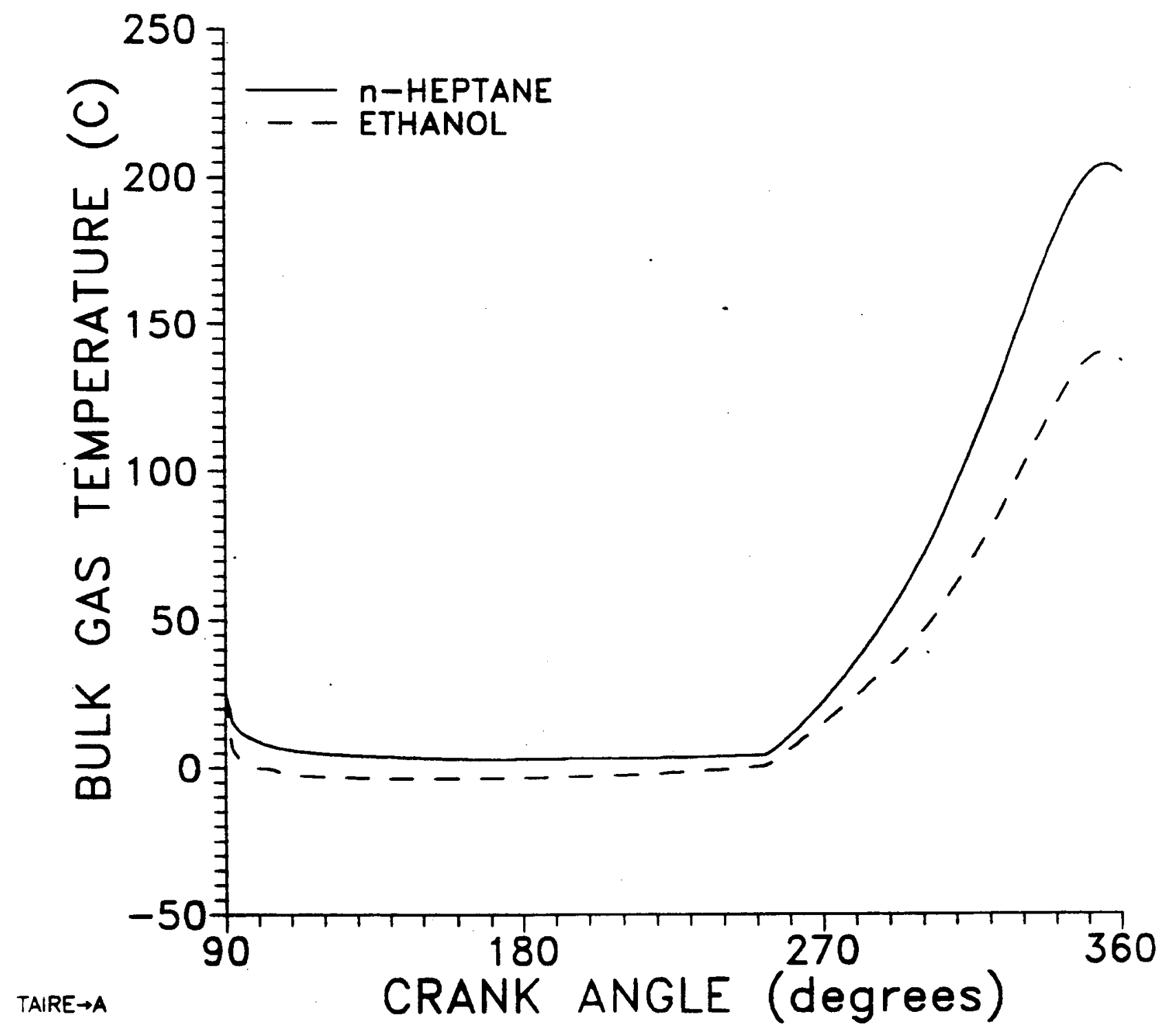

FIGURE 23. COMPUTED IN-CYLINDER GAS TEMPERATURE WITH GASOLINE (N-HEPTANE) AND NEAT ETHANOL FUEL SPRAY WITH SMD=10 MICROMETERS (ROSINRAMMIER N = 1.5) FOR FORD TAURUS 3.0-LITER V-6 CRANKING AT 250 rpm, 25 DEGREES C AIR AND ENGINE 


$$
\begin{aligned}
& \text { BULK GAS TEMPERATURE } \\
& 3-\text { Liter Ford, } 170 \text { rpm, } 0 \\
& \text { SMD }=10 \mu \mathrm{m}, \phi=1.0, C R=9.3
\end{aligned}
$$

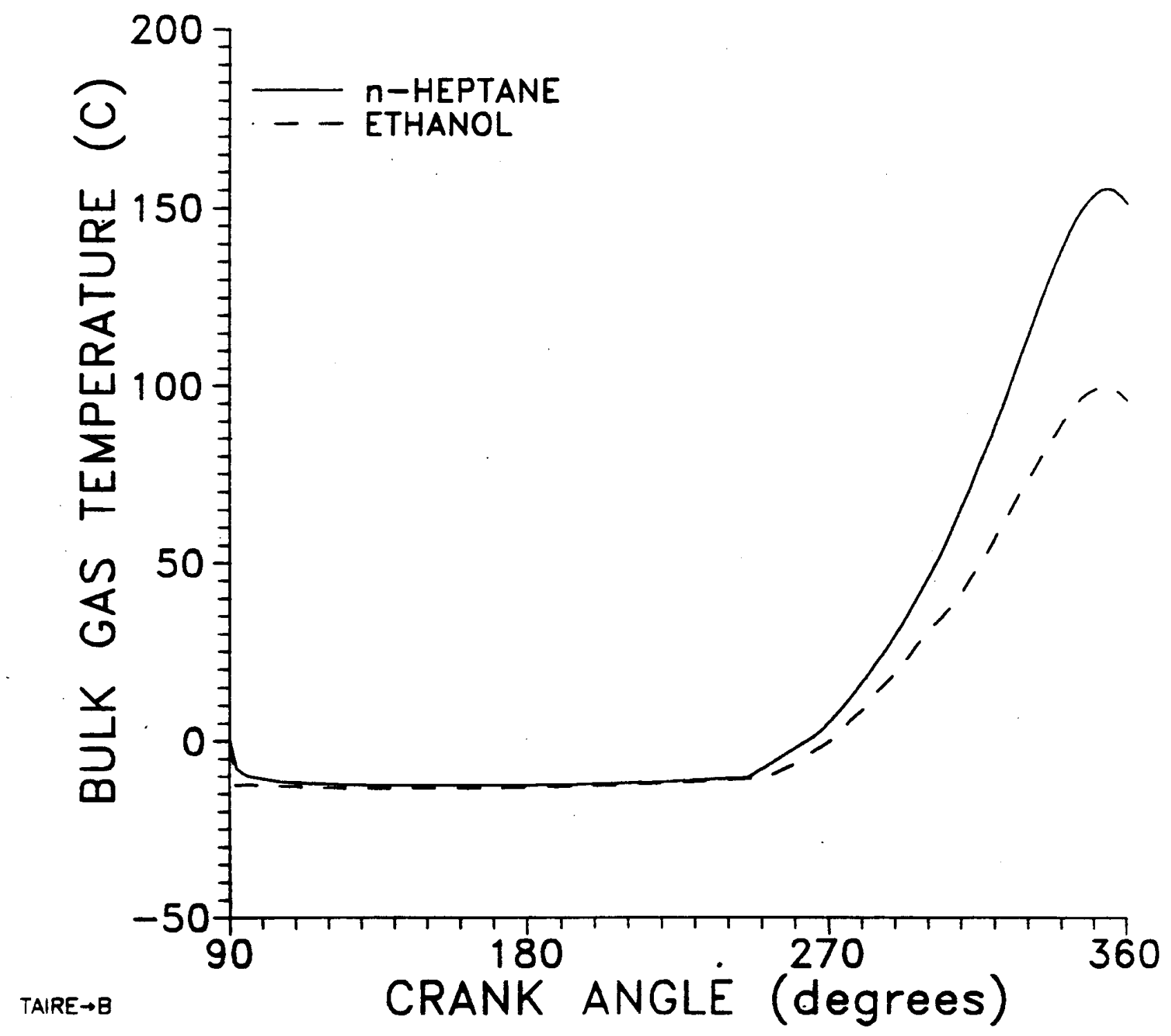

FIGURE 24. COMPUTED IN-CYLINDER GAS TEMPERATURE WITH GASOLINE (N-HEPTANE AND NEAT ETHANOL FUEL SPRAY WITH SMD=10 MICROMETERS (ROSINRAMMLER $N=1.5$ ) FOR FORD TAURUS 3.0-LITER V-6 CRANKING AT $170 \mathrm{rpm}$, O DEGREES C AIR AND ENGINE 
the addition of more fuel, but for ethanol, the extra fuel was only partially vaporized. There was simply very little thermal energy available in the ethanol case to evaporate any more fuel. In practical applications, the ethanol-fueled engine may be helped in cold-starting by enrichment, because some fuel will be lost on the port walls and the combustion chamber walls. However, Figures 28 and 29 show that fuel enrichment for ethanol is not nearly as beneficial as for gasoline-fueled engines.

How can low-temperature cold-starts be achieved with the ethanol fuels if enrichment does not help in the in-cylinder evaporation? The addition of hydrocarbon light-ends can be used, of course. Also, direct spark vaporization and ignition is potentially attractive if the spray can be retained in the air. The concept of direct spark vaporization and ignition will be addressed in the engine tests during this project. Ethanol fuel has a much higher octane number than gasoline, so higher compression ratios may be used, increasing the compression temperature. Interestingly, this only results in slight improvements in the amount of fuel vaporized, as shown in Figure 30. However, the increased compression ratio helps cycle efficiency considerably, and should be employed for dedicated ethanol engines, as shown below.

Some calculations were performed with the combined TESS and cycle simulation computer models to estimate the efficiency that might be expected at a road load condition for ethanol fuel as compared with gasoline fuel, and for the effect of increasing the compression ratio from the standard 9.3 to 12.0. The road load was assumed to be the Ford Taurus 3.0-liter engine operating at $2100 \mathrm{rpm}$, stoichiometric fuelair ratio, intake manifold pressure of $40 \mathrm{kPa}_{\text {absolute }}$, exhaust pressure of $102 \mathrm{kPa}_{\text {absolute }}$, barometric pressure

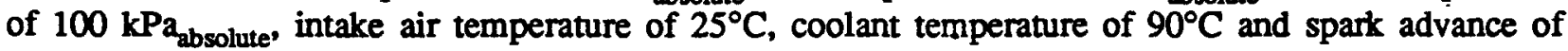
$23^{\circ} \mathrm{BTDC}$ (before top-dead-center). On n-heptane fuel, the brake mean effective pressure (BMEP) was predicted to be $184 \mathrm{kPa}(27 \mathrm{psi})$, and the power was $9.6 \mathrm{~kW}$ (12.9 $\mathrm{HP})$.

As shown in Table 8, if the same air flow conditions and speeds are assumed, the model predicts higher output power for ethanol compared to heptane because of the much reduced pumping losses due to the charge cooling of the ethanol. For these conditions, the brake thermal efficiency (BTE) is predicted to increase by about 5.5 percent relative to gasoline. In fact, if power rather than air flow was fixed, then the pumping losses would be slightly increased for the ethanol fuel case and the efficiency gain would be less than shown in Table 8. On the other hand, the faster bumer speed of ethanol than heptane would increase the BTE slightly. These efficiency calculations are based on the energy content of the fuel, and do not include losses associated with the greater vehicle mass of the ethanol fuel.

An increase in compression ratio from 9.3 to 12.0 is predicted to increase the BTE significantly for the ethanol fuel. The high compression ratio is not practical for gasoline. The increased BTE is again based on constant air mass flow rate through the engine rather than constant output power, and the BTE gain with the high compression ratio would be reduced if the computations were at constant power. These engine efficiency calculations were based on computed pumping losses, compression losses including cylinder pressure reductions due to cooling in evaporating the liquid fuel, estimated buming rates using a Wiebe function, and friction losses based on typical spark ignition engines, but not including the additional frictional losses associated with the increase in compression ratio. In fact, the increase in frictional losses and heat transfer with increasing compression ratio typically limits the compression ratio maximum thermal efficiency with a spark-ignition engine to about 17 (Heywood, 1988).

\section{Engine Control System Design}

\section{Need for Custom Engine Control Unit (ECU)}

Meeting ULEV requirements with an ethanol-fueled vehicle while maintaining driveability and cold-start capability will require significant modification and extension of the engine control unit currently used in 

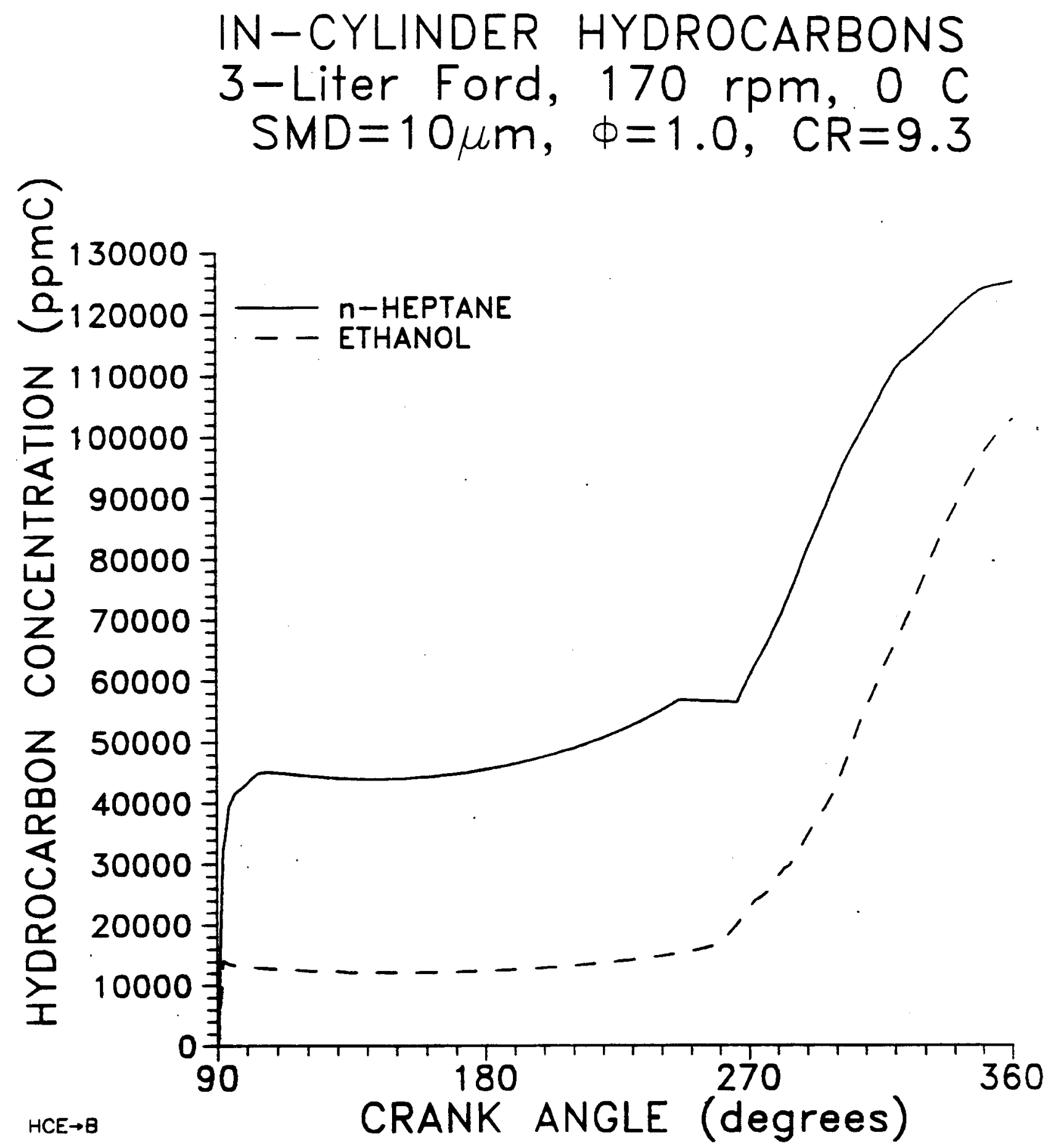

FIGURE 25. COMPUTED IN-CYLINDER HYDROCARBONS WITH N-HEPTANE (SIMULATING GASOLINE) AND NEAT ETHANOL FUEL SPRAY WITH SMD=10 MICROMETERS (ROSIN-RAMMLER N=1.5) FOR FORD TAURUS 3.0-LITER V-6 CRANKING AT 170 rpm, 0 DEGREES C AIR AND ENGINE 


\section{$n$-HEPTANE VAPOR PRESSURES \\ 3-Liter Ford, $170 \mathrm{rpm}, 0 \mathrm{C}$ $S M D=10 \mu \mathrm{m}, \quad \phi=1.0, \quad C R=9.3$}

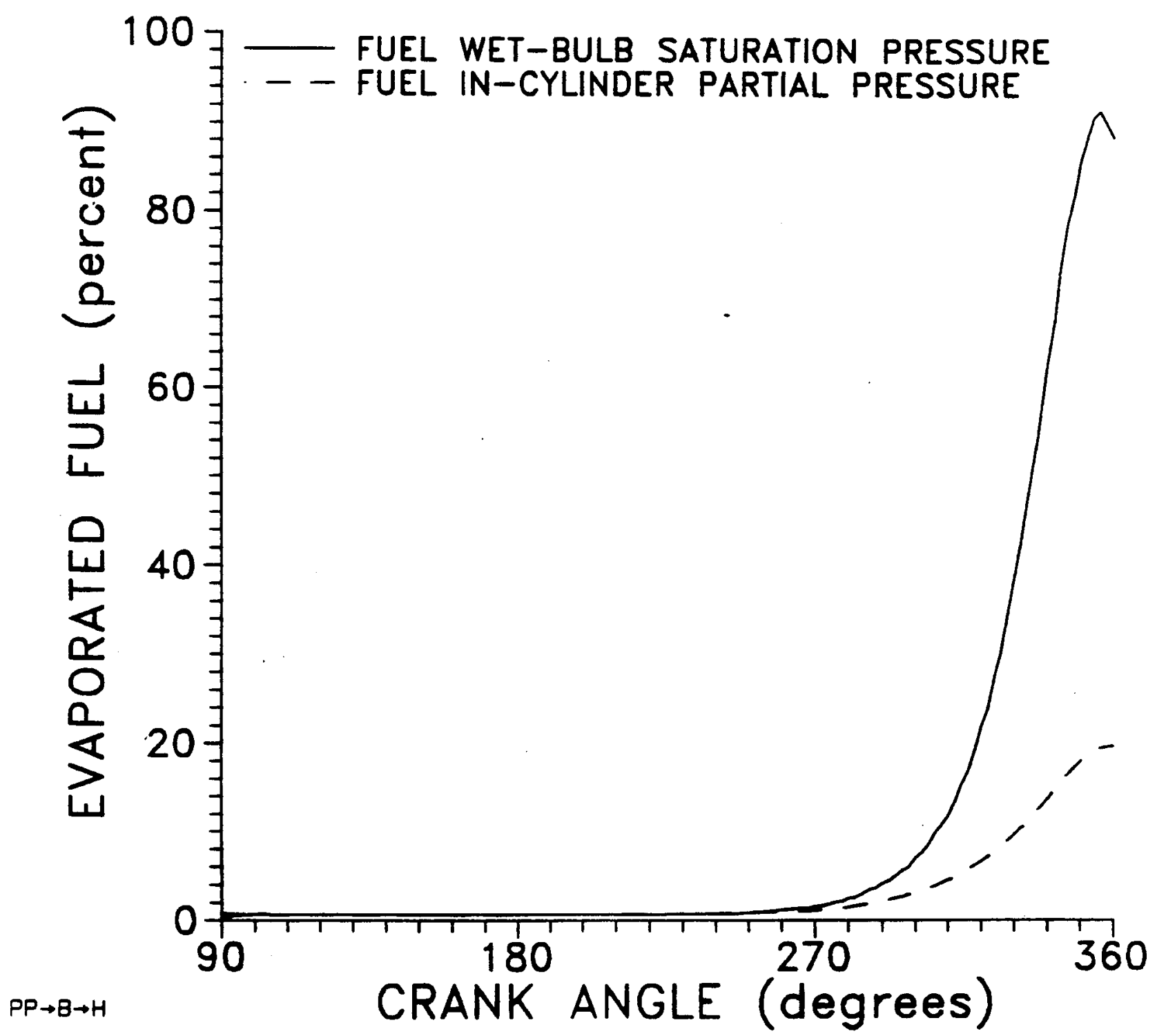

FIGURE 26. COMPUTED N-HEPTANE VAPOR PRESSURES FOR FUEL SPRAY WITH SMD=10 MICROMETERS (ROSIN-RAMMLER N=1.5) FOR FORD TAURUS 3.0-LITER V-6 CRANKING at $170 \mathrm{rpm}, 0$ DEGREES C AIR AND ENGINE 


\section{ETHANOL VAPOR PRESSURES 3-Liter Ford, $170 \mathrm{rpm}, 0 . \mathrm{C}$ $S M D=10 \mu \mathrm{m}, \quad \phi=1.0, \quad C R=9.3$}

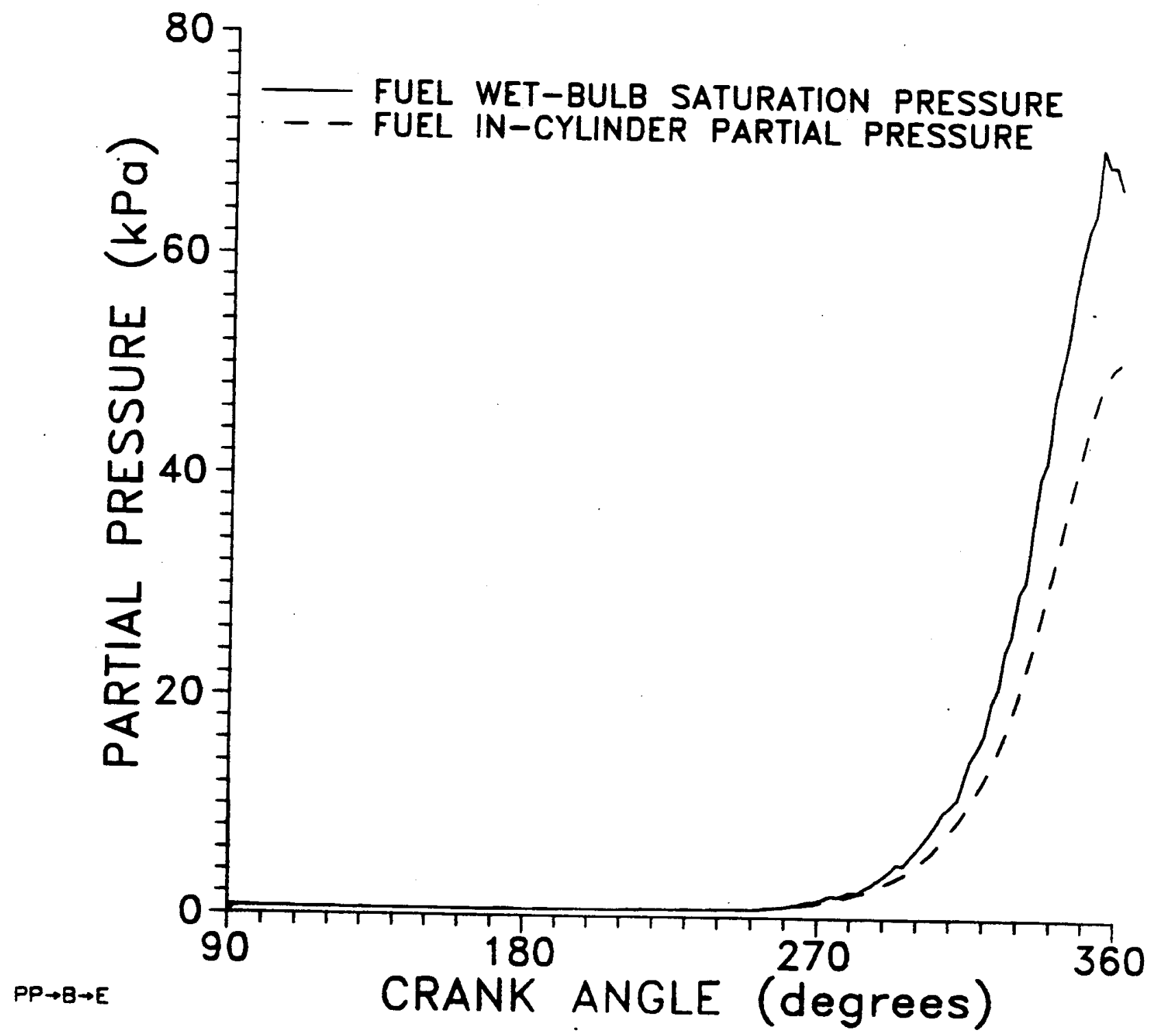

FIGURE 27. COMPUTED NEAT ETHANOL VAPOR PRESSURES FOR FUEL SPRAY WITH SMD=10 MICROMETERS (ROSIN-RAMMLER N=1.5) FOR FORD TAURUS 3.0-LITER V-6 CRANKING AT 170 rpm, 0 DEGREES C AIR AND ENGINE 


\section{ENRICHMENT EFFECT ON HC VAPOR 3-Liter Ford, $170 \mathrm{rpm}, \mathrm{O} \mathrm{C}$ $S M D=10 \mu \mathrm{m}, C R=9.3$}

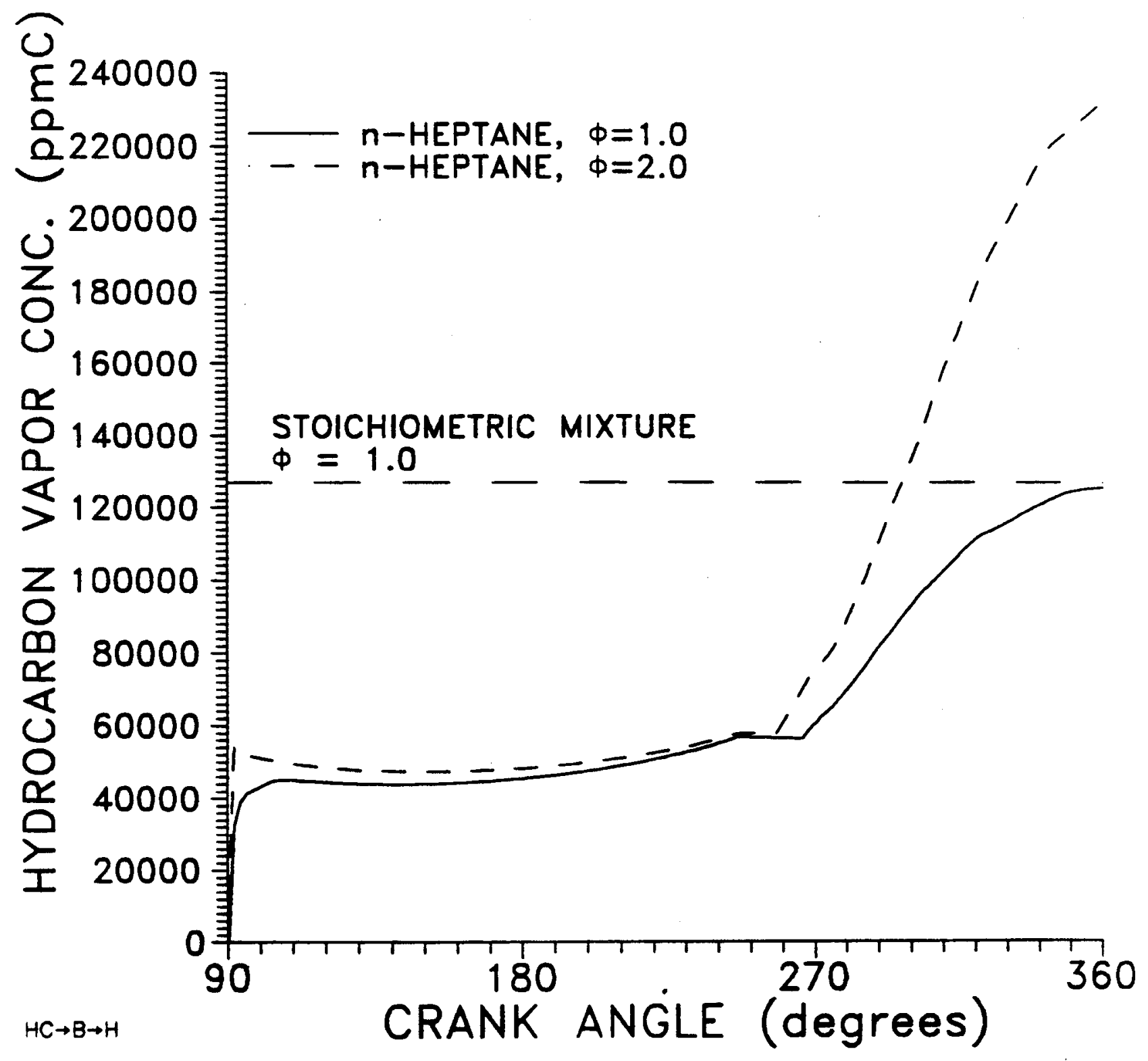

FIGURE 28. ENRICHMENT EFFECT ON COMPUTED IN-CYLINDER HYDROCARBON CONCENTRATION FOR N-HEPTANE (SIMULATING GASOLINE) FUEL SPRAY WITH SMD=10 MICROMETERS (ROSIN-RAMMLER N=1.5) FOR FORD TAURUS 3.0-LITER V-6 CRANKING AT 170 rpm, 0 DEGREES C AIR AND ENGINE 


\section{ENRICHMENT EFFECT ON HC VAPOR 3-Liter Ford, $170 \mathrm{rpm}, 0 \mathrm{C}$ $S M D=10 \mu \mathrm{m}, C R=9.3$}

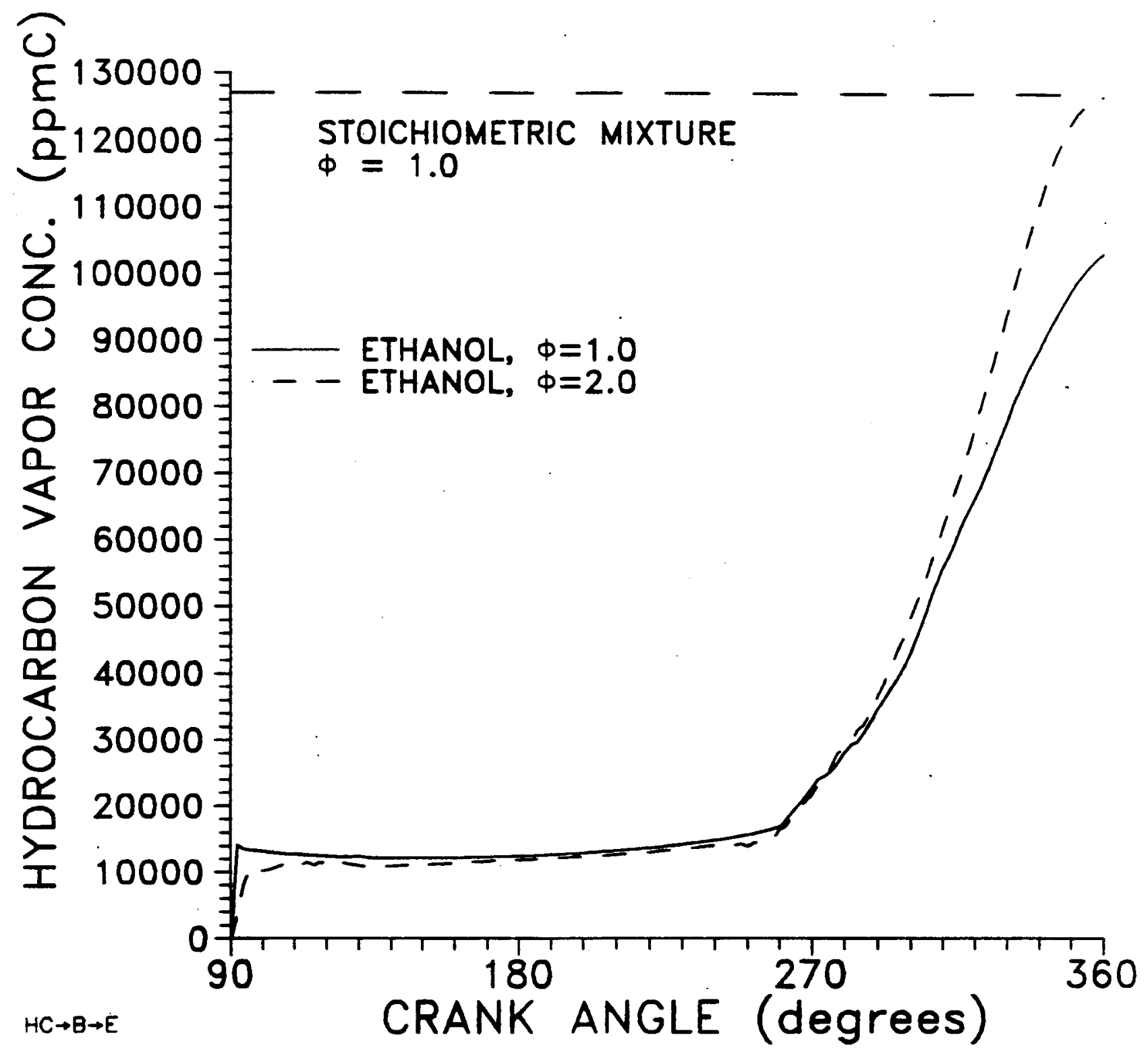

FIGURE 29. ENRICHMENT EFFECT ON COMPUTED IN-CYLINDER HYDROCARBON CONCENTRATION FOR NEAT ETHANOL FUEL SPRAY WITH SMD=10 MICROMETERS (ROSIN-RAMMLER N=1.5) FOR A FORD TAURUS 3.0-LITER V-6 CRANKING AT $170 \mathrm{rpm}$, O DEGREES C AIR AND ENGINE 


\section{IN-CYLINDER EVAPORATION 3-Liter Ford, $170 \mathrm{rpm}, \mathrm{O} \mathrm{C}$ $S M D=10 \mu \mathrm{m}, \phi=1.0$}

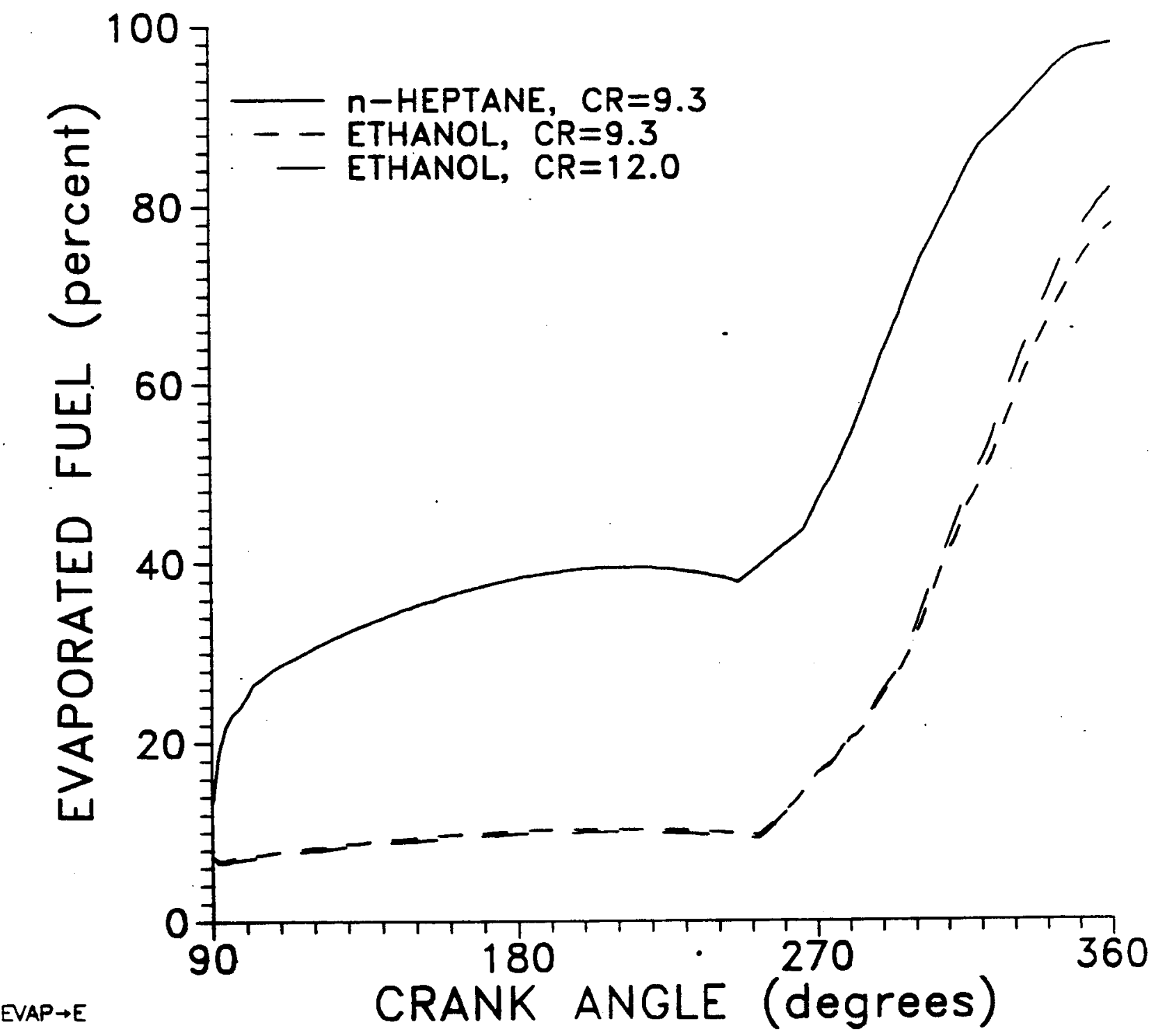

FIGURE 30. EFFECT OF INCREASED COMPRESSION RATIO ON COMPUTED INCYLINDER EVAPORATION FOR NEAT ETHANOL (COMPARED TO N-HEPTANE) FUEL SPRAY WITH SMD=10 MICROMETERS (ROSIN-RAMMLER N=1.5) FOR A FORD TAURUS 3.0-LITER V-6 CRANKING AT 170 rpm, 0 DEGREES C AIR AND ENGINE 
the Ford Taurus FFV. In addition, the controller requirements can not be accurately known or completely guessed prior to experimental testing. Both of these factors strongly justify the need for a custom engine control unit (ECU) for the converted vehicle.

\section{TABLE 8. COMPARISON OF FUEL EFFECTS ON PREDICTED POWER AND EFFICIENCY}

\begin{tabular}{|c|c|c|c|c|c|}
\hline Fuel & Comp. Ratio & $\begin{array}{c}\text { BMEP } \\
(\mathrm{kPa})\end{array}$ & $\begin{array}{c}\text { Power } \\
(\mathrm{kW})\end{array}$ & $\begin{array}{c}\text { Brake } \\
\text { Thermal } \\
\text { Efficiency } \\
(\%)\end{array}$ & $\begin{array}{c}\text { Percent } \\
\text { Improve. } \\
\text { Relative to } \\
\text { Heptane }\end{array}$ \\
\hline \hline \begin{tabular}{c} 
n-Heptane \\
\hline $\begin{array}{c}\text { Ethanol } \\
\text { (E100) }\end{array}$
\end{tabular} & 9.3 & 184 & 9.6 & 18.3 & 0.0 \\
\hline $\begin{array}{c}\text { Methanol } \\
\text { (M100) }\end{array}$ & 9.3 & 198 & 13.8 & 19.3 & 5.5 \\
\hline $\begin{array}{c}\text { Ethanol } \\
\text { (E100) }\end{array}$ & 12.0 & 243 & 17.0 & 22.7 & 24.0 \\
\hline $\begin{array}{c}\text { Methanol } \\
\text { (M100) }\end{array}$ & 12.0 & 255 & 17.9 & 23.5 & 28.4 \\
\hline
\end{tabular}

First, the different characteristics of the ethanol fuel itself will require adjustment of the injection and ignition timing strategies and maps. Increased compression ratio will also cause changes in timing strategies. Although it is conceivable that the timing maps could be changed in the existing ECU, it is unreasonable to expect to achieve radical redesign of the timing strategy itself within the existing ECU. With a new, custom ECU, however, complete redesign of the strategy itself is not a problem.

Secondly, the use of air-assist injectors, electrically-heated (or burner-heated) catalyst, and higher-energy ignition systems places additional requirements on the engine controller which can not be met with the existing ECU. Air-assist injectors require control of the air-assist compressor, and may also require realtime modulation of the air-assist pressure (most probably through the use of an electrically-controlled regulator). In addition to controlling the heating element (either electrical or bumer) in the catalyst, it is also necessary to modify the engine operating conditions for fastest catalyst light-off. To maximize the spark-energy, either extended dwell-times or multiple sparks will be used. All of these new requirements necessitate the use of a custom ECU.

Finally, the cold-start problem will require extensive modification of the normal operating strategy. The ignition and injection timing must be manipulated, the ignition energy must be increased beyond the acceptable steady-state value and the air-to-fuel ratio must be decreased, all on a cycle-by-cycle basis during the start-up process. Even if some of this capability exists in the stock ECU, it certainly does not exist with sufficient flexibility to achieve ULEV performance and cold-start capability using ethanol. 


\section{Recommended ECU Design}

In order to achieve a high degree of flexibility with minimum design cost, a PC-based ECU will be used. Using SwRI-developed real-time extensions to the standard MS-DOS operating system, the controller consists of a 80486 based personal computer that drives custom designed printed circuit boards through a standard analog and digital L/O card.

\section{Test Cell Engine Controller}

The engine test cell version of this controller is shown in Figure 31. The key to this set-up is the realtime operating system extensions together with the custom boards. The custom boards off-load the most time-critical engine control operations, such as injector and ignition timing. Because of this reduction in the PC's timing requirements, all control codes may be written in the high-level language $C$. In this way, new control strategies may be very efficiently and quickly implemented and tested.

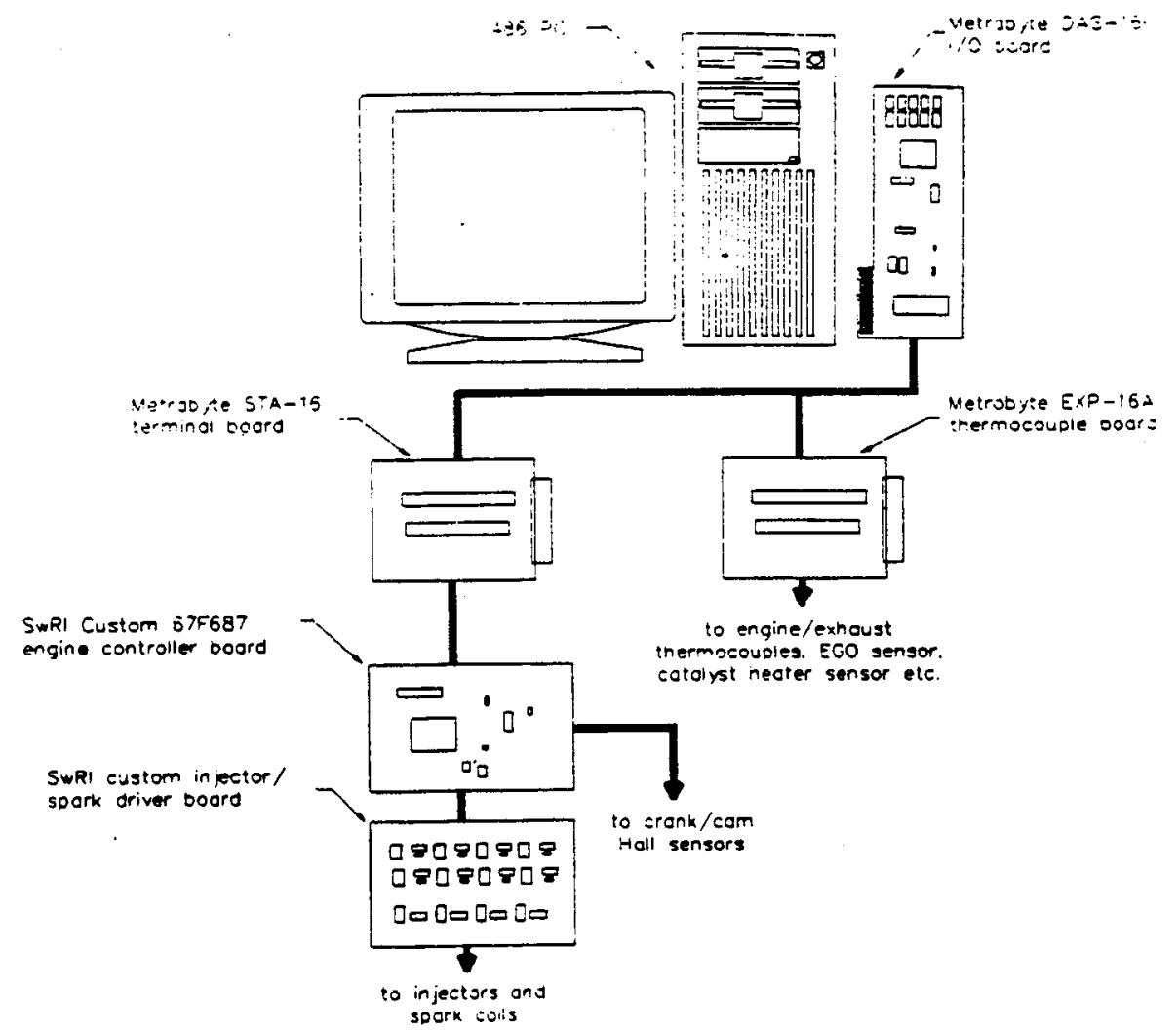

FIGURE 31. THE PC-BASED CONTROLLER FOR ENGINE TEST CELL

The controller shown in Figure 31 is suitable for most of the anticipated testing of the dedicated ethanol ULEV with the exception of multiple or high-energy sparks during cranking and start-up. For the control system of Figure 31 to produce multiple sparks per cycle, it would be necessary for the Engine Controller Board to interrupt the PC prior to each spark. In order to achieve a high enough number of sparks per cycle for sufficient ignition energy, it is required that each spark (including dwell time) must be only approximately 20 to $50 \mathrm{~ms}$. For fairly complex PC controller code, this interrupt timing is too fast. To alleviate this requirement, the controller is modified according to Figure 32 . In this new scheme, the ignition timing is controlled by an SwRI designed, Motorola MC68HC11 Microcontroller Board. The spark timing and "duration" (i.e., the amount of time to continue sparking) is supplied to the microcontroller board by the 67F687 engine controller, with the MC68HC11 actually firing the coil. 
The hardware requirements associated with the engine test cell controller incorporating the features shown In Figures 31 and 32 are given in Table 9, with the detailed breakout of the custom printed circuit boards given in Appendix A.

TABLE 9. PARTS LIST FOR ENGINE TEST CELL PC-BASED CUSTOM ECU

\begin{tabular}{|c|c|}
\hline Description & Quantity \\
\hline 80486 Personal Computer & 1 \\
\hline Metrobyte DAS-1602 I/O Board & 1 \\
\hline Metrobyte STA-16 I/O Box & 1 \\
\hline Metrobyte EXP-16A I/O Box & 1 \\
\hline Metrobyte C-1800 Interface Cable & 1 \\
\hline Metrobyte C-1600 Interface Cable & 1 \\
\hline Metrobyte PG-408A Power Supply & 1 \\
\hline 68HC11 Microcontroller Board & 1 \\
\hline 67F687 Engine Controller Board & 2 \\
\hline Injector/Spark Driver Board & 2 \\
\hline Custom Board Power Supply & 1 \\
\hline
\end{tabular}

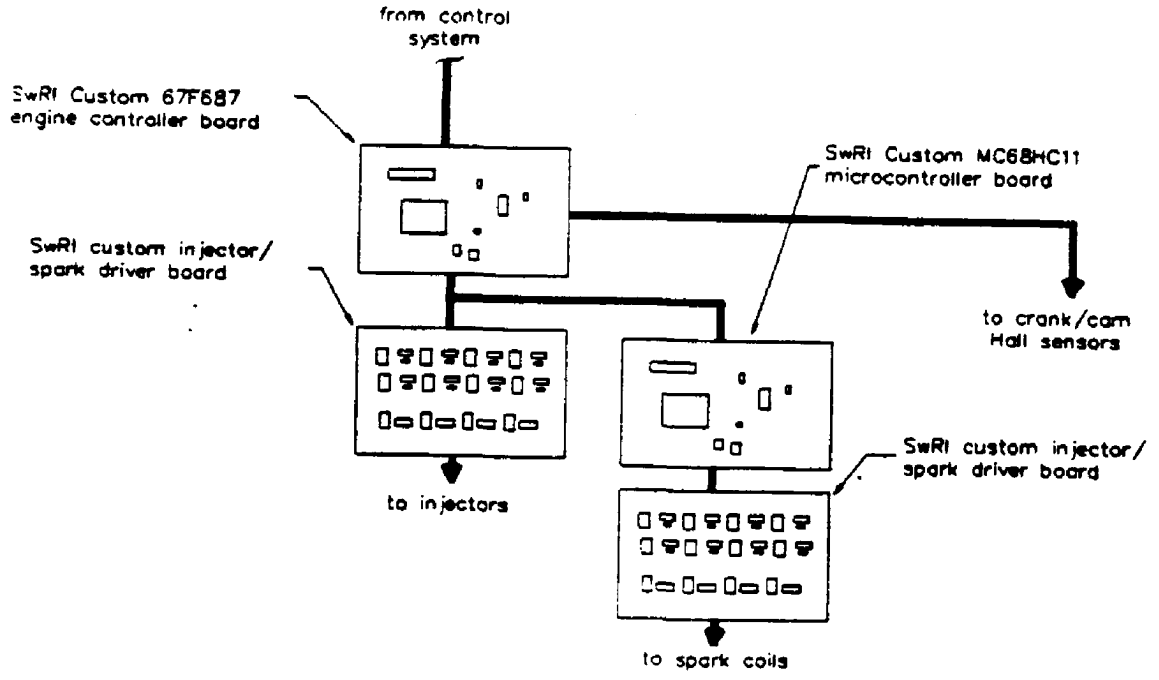

FIGURE 32. MODIFICATIONS TO PC ENGINE CONTROLLER FOR MULTIPLE SPARKS 


\section{In-Vehicle Engine Controller}

The proposed ECU of Figures 31 and 32 provides a high degree of flexibility for controller algorithm development. It is not, however, suitable for in-vehicle use, because it uses a standard personal computer, which is not physically rugged enough to be used in the vehicle. To overcome this difficulty, the design of Figures 31 and 32 is modified according to that given in Figure 33. The three real differences between the two designs are that the in-vehicle design uses a hardened enclosure, a $12 \mathrm{~V}$ power supply, and a solidstate boot disk. Additionally, the in-vehicle ECU must interface to the stock original equipment manufacturer (OEM) ECU in order to maintain the diagnostic capability of the stock ECU (a feature which is not required in the engine test cell custom ECU). Note that the serial port in Figure 33 will be used to link the ECU to a laptop computer (not shown) for the real-time display of the ECU state, and for reprogramming the ECU. Note finally that the ECU of Figure 32 does not explicitly show the multiple spark ignition equipment of Figure 32 , but this equipment can be easily added if such capability is required in-vehicle.

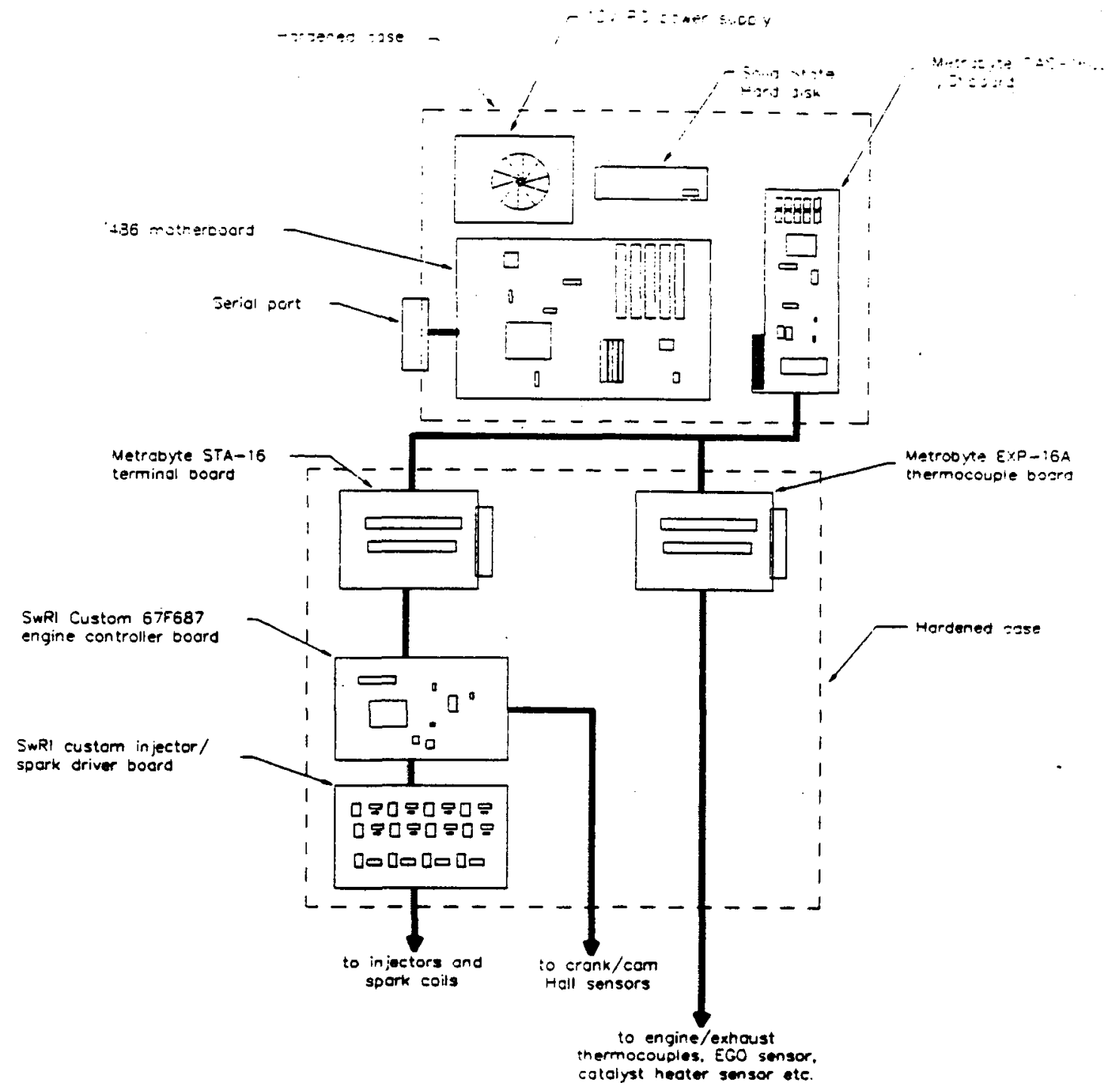

FIGURE 33. THE ENGINE CONTROLLER FOR IN-VEHICLE WORK 
A parts list for the in-vehicle ECU is given in Table 10. Note that this parts list assumes that the input/output and custom boards used in the test-cell controller are transferred to the vehicle controller, so that new ones need not be bought or built.

\section{TABLE 10. PARTS LIST FOR IN-VEHICLE PC-BASED CUSTOM ECU}

\begin{tabular}{|c|c|}
\hline Description & Quantity \\
\hline \hline DTI 80486 Hardened Motherboard & 1 \\
\hline DTI 10 Slot Chassis & 1 \\
\hline DTI 4M Solid-State SRAM Disk & 1 \\
\hline Altex 12VDC to 110VAC 200 W Inverter & 1 \\
\hline
\end{tabular}

\section{Project Scope Additions}

There are two primary reasons for adding to the project scope of Task 3 - Engine System. The first proposed addition results from the discovery, through the literature survey, that increased driveability of ethanol-fueled vehicles may be realized through increased ignition system energy. The second or third proposed project scope additions (which are mutually exclusive) will allow SwRI to expedite the project by upgrading the control system to allow for both ease of vehicle installation and for high-speed data analysis. A full cost estimate for these additions will follow in a formal cost proposal.

\section{High-Energy Ignition System}

The cycle simulation/spray evaporation study of ethanol fuel indicates that sufficient vaporization of neat ethanol does not occur in-cylinder for reliable engine start-up at extremely cold temperatures even when very fine droplets are injected. There are two strategies for overcoming this problem: (1) use highly volatile additives in the fuel formulation or (2) provide for high-energy sparks which will both vaporize additional fuel and increase the air-to-fuel ratio lean-limit. The first technique is of only limited use, because increasing the high volatility additives leads to evaporative emissions problems. (This tradeoff is minimized, however, if one is willing to use different fuel formulations for different seasonal conditions.)

The second method, high-energy ignition, may or may not be as effective as fuel additives, but does not suffer from the increased evaporative emissions drawback. In fact, a high-energy ignition system should actually increase the efficiency of the engine under all operating conditions.

There are two primary techniques for increasing the ignition energy. The first and most obvious is simply to increase the energy dumped to the plug by storing more energy in the coil. However, this usually requires larger spark plug gaps and the high-energy sparks must be used at all engine conditions. This can lead to increased spark plug wear. The second, which is more complex but possibly superior, is to use multiple sparks per cycle when ignition assist is needed (cold engine). Using this technique, multiple sparks can be limited to cranking and cold operation, avoiding increased spark plug wear. It is proposed that both techniques be examined. 
The ECU's discussed above are capable of producing both effects, but both effects may require the replacement of the stock Ford Taurus ignition coil. Moreover, the two competing approaches require coil characteristics that are quite different. The high-energy, single spark scheme requires a coil with a relatively high inductance, so that the energy stored by the coil is maximized. But this leads to relatively long charge times, which severely hinders the ability to produce multiple sparks. Thus, we need a high inductance coil for high-energy single spark, and a low inductance coil for low-energy multiple spark.

To test both schemes, it will be required to purchase two new coils. Several aftermarket vendors are under consideration, including Accel, MSD and Autotronic.

\section{DSP-Based Engine Controller}

The PC-based design specified above has the significant advantage of low design cost. All of the components are either off-the-shelf or have already been designed. The PC-based design suffers, however, from a significant disadvantage: it not capable of computationally intensive real-time analysis (such as real-time indicated mean effective pressure (IMEP) calculations from cylinder pressure data).

Under the originally proposed schedule, this disadvantage does not pose a severe problem. High-speed data would either be post-processed (i.e., not analyzed in real-time), or it would be analyzed in real-time with existing SwRI equipment. However, both of these altematives severely limit SwRI's capability to expedite the project schedule. Post-processing of the high-speed data introduces a lag time, such that the knowledge gained from the analysis can not be put to use as efficiently or as quickly. The use of existing real-time equipment limits the expediting of the project because this equipment is in high demand by several projects.

This problem may be eliminated by replacing the PC "brain" of the ECU's of Figures $31-33$ with a custom, digital signal processor (DSP) based microprocessor board, as shown in Figure 34. This upgraded controller has all of the real-time high-speed data analysis capability built in, thus avoiding the difficulties discussed above. Additionally, this upgraded controller should be easier to integrate into the vehicle, because it is both physically smaller and more flexible.

The DSP chip upon which the ECU of Figure 34 is based is the Texas Instruments TMS320C31 singleprecision floating point unit. This chip is capable of a sustained maximum throughput of 33 million floating point operations per second (MFLOP), with an average of about 8 MFLOP. In contrast, a 66 $\mathrm{MHz} 80486 \mathrm{DX} 2$ can achieve an average of about 3 MFLOP. Even this comparison is misleading, because the ECU of Figure 34 does not use an operating system per se, and thus does not have the overhead of an operating system. In actual use, it is reasonable to expect that the DSP based system will have a computational capability an order of magnitude greater than the PC based system. This additional processing power gives the ECU of Figure 34 the real-time engine performance analysis capability.

Furthermore, the ECU of Figure 34 replaces the entire PC component of Figure 33 with a single custom board. It is reasonable to expect that the physical size of the ECU of Figure 34 will be approximately one fourth that of the ECU of Figure 33. Thus, the real-time engine analysis features discussed above are gained not at the expense of increased bulk or weight, but rather with the minimization (if not elimination) of the need for passenger compartment space.

\section{Extra Sets of ECU Boards}

The PC-based controller proposed above calls for purchasing only one set of input/output and custom boards. These boards would first be used in the test-cell controller. Only after engine-test cell work is 
completed would these boards be transferred to the vehicle. Thus, engine-test cell and vehicle work could not be accomplished simultaneously. Obviously, this approaches saves the cost of an extra set of boards, but it also requires more time than if both systems were operational simultaneously. It is proposed that an extra set of boards be purchased to expedite the project.

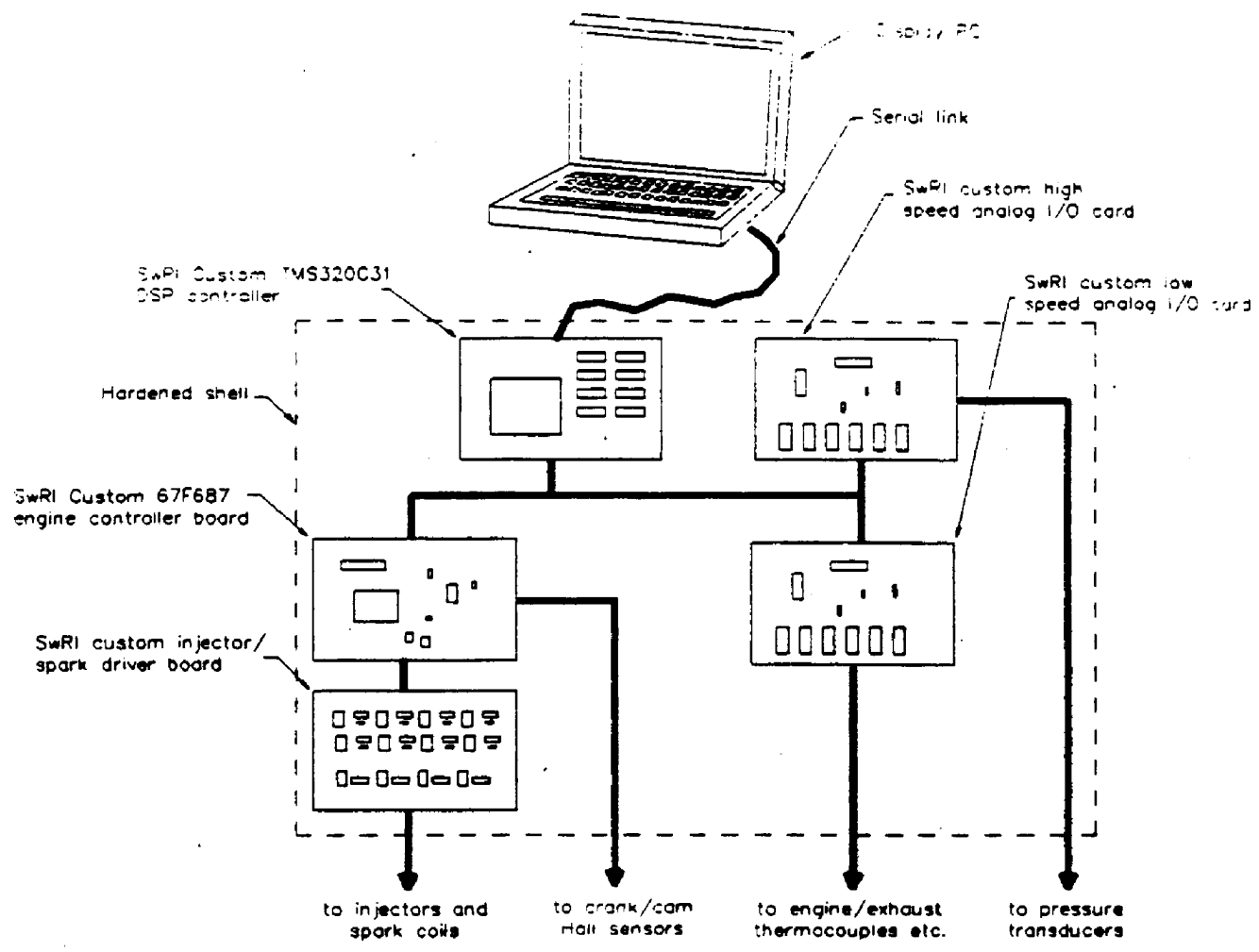

FIGURE 34. THE TMS320C31 DSP-BASED ENGINE CONTROLLER

Note that this proposed addition is also relevant if the DSP-based ECU above is accepted. In this event, it is proposed that two DSP-based ECU's be constructed, so that simultaneous engine test-cell and vehicle work may be carried out. 


\section{TASK 4 - EMISSIONS CONTROL SYSTEM DESIGN}

The following section details the emissions control efforts to be undertaken in this program. This discussion covers both exhaust and evaporative emission issues including:

- demonstration of the need for enhanced aftertreatment

- a literature review of aftertreatment strategies and their potential for helping to achieve ULEV exhaust emissions standards for this program

- a discussion of evaporative emission issues

- a summary of the emission control system evaluations planned for this vehicle

\section{Exhaust Emissions Control}

The California Low Emissions Vehicle Program requires significant reductions in automotive exhaust emissions. To achieve these reductions, improvements in aftertreatment will be needed, especially during cold-start conditions (i.e. after a 12- to 36-hour soak at room temperature). The need for further control of exhaust emissions during cold-start can be seen by examining the weighted U.S. Federal Test Procedure (FTP) exhaust data shown in Table 11 (Heimrich et.al., 1991) for two current technology vehicles meeting or near transitional low emission vehicle (TLEV) standards. A large percentage of the weighted exhaust emissions are produced in the first 140 seconds of the first bag of the FTP for all exhaust constituents.

\section{TABLE 11. FTP EXHAUST EMISSION FOR TWO CURRENT-TECHNOLOGY VEHICLES}

\begin{tabular}{|c|c|c|c|c|c|c|c|}
\hline \multirow{2}{*}{ Vehicle } & \multirow{2}{*}{$\begin{array}{l}\text { Exhaust } \\
\text { Emission }\end{array}$} & \multicolumn{4}{|c|}{$\begin{array}{l}\text { Individually Weighted Exhaust Emissions } \\
\qquad(\mathrm{g} / \mathrm{mi})\end{array}$} & \multirow{2}{*}{$\begin{array}{l}\text { Total } \\
\text { Weighted } \\
\text { FTP } \\
\text { Emissions } \\
\text { (g/mi) }\end{array}$} & \multirow{2}{*}{$\begin{array}{c}\text { Bag 1A } \\
\text { Percentage } \\
\text { of Total } \\
\text { Emissions }\end{array}$} \\
\hline & & $\begin{array}{c}\text { Bag 1A } \\
(0-140 \mathrm{sec})\end{array}$ & $\begin{array}{c}\text { Bag 1B } \\
(141-505 \\
\text { sec })\end{array}$ & Bag 2 & Bag 3 & & \\
\hline $\begin{array}{l}\text { '90 Buick } \\
\text { LeSabre }\end{array}$ & $\begin{array}{c}\mathrm{THC} \\
\mathrm{CO} \\
\mathrm{NO}_{\mathrm{x}}\end{array}$ & $\begin{array}{l}0.08 \\
0.50 \\
0.08\end{array}$ & $\begin{array}{l}0.01 \\
0.06 \\
0.01\end{array}$ & $\begin{array}{l}0.05 \\
0.58 \\
0.00\end{array}$ & $\begin{array}{l}0.03 \\
0.40 \\
0.06\end{array}$ & $\begin{array}{l}0.18 \\
1.53 \\
0.15\end{array}$ & $\begin{array}{l}45 \% \\
32 \% \\
53 \%\end{array}$ \\
\hline $\begin{array}{l}\text { '90 Toyota } \\
\text { Celica }\end{array}$ & $\begin{array}{c}\mathrm{THC} \\
\mathrm{CO} \\
\mathrm{NO}_{\mathrm{x}}\end{array}$ & $\begin{array}{l}0.06 \\
0.47 \\
0.03\end{array}$ & $\begin{array}{l}0.00 \\
0.00 \\
0.02\end{array}$ & $\begin{array}{l}0.01 \\
0.04 \\
0.02\end{array}$ & $\begin{array}{l}0.01 \\
0.01 \\
0.01\end{array}$ & $\begin{array}{l}0.08 \\
0.52 \\
0.09\end{array}$ & $\begin{array}{l}77 \% \\
89 \% \\
39 \%\end{array}$ \\
\hline
\end{tabular}

For comparison, the California LEV Program standards are summarized in Table 12. As can be seen in the Table 12, significant reductions in all exhaust emission species are required in going from one emission standard to the next. As demonstrated in Table 11, most of these exhaust emission reductions need to be made in the first few minutes of FTP operation. As will be shown in the following discussion, potential reductions are thought to be achievable utilizing a combination of supplemental aftertreatment, reformulated main catalyst, and insulated exhaust system. 


\section{TABLE 12. CALIFORNIA 50,000 MIIE LEV PROGRAM LIGHT-DUTY VEHICLE EMISSIONS STANDARDS SUMMARY}

\begin{tabular}{|l||c|c|c|c||}
\hline \multicolumn{1}{|c|}{$\begin{array}{c}\text { Exhaust } \\
\text { Constituent }\end{array}$} & TLEV & LEV & ULEV & $\begin{array}{c}\text { TLEV to ULEV } \\
\text { Percent } \\
\text { Reduction }\end{array}$ \\
\hline \hline NMOG $(\mathrm{g} / \mathrm{mi})$ & 0.125 & 0.075 & 0.040 & $68 \%$ \\
\hline CO $(\mathrm{g} / \mathrm{mi})$ & 3.4 & 3.4 & 1.7 & $50 \%$ \\
\hline $\mathrm{NO}_{\mathrm{x}}(\mathrm{g} / \mathrm{mi})$ & 0.4 & 0.2 & 0.2 & $50 \%$ \\
\hline Formaldehyde $(\mathrm{mg} / \mathrm{mi})$ & 15 & 15 & 8 & $47 \%$ \\
\hline
\end{tabular}

\section{Supplemental Aftertreatment}

The cold-start portion of the FTP produces such a large percentage of total mass emissions because the engine and exhaust systems are cold and the catalytic converter is not yet working at high efficiency. In addition, the engine operates with an air-to-fuel ratio on the rich side of stoichiometric to maintain driveability. Light-off temperature, the temperature at which a catalyst can convert 50 percent of exhaust emissions, generally occurs at $350^{\circ} \mathrm{C}$ for hydrocarbons. Several aftertreatment strategies have been able to overcome the rich engine operation and poor catalyst conversion efficiencies during the first few moments of the FTP to reduce cold-start emissions. For example, current generation flexible-fuel vehicles manufactured by GM, Ford, and Volkswagen have been able to meet Califormia TLEV emissions standards operating on E-80 when utilizing a calculated reactivity adjustment factor (Kroll et al., 1993; Marshall, 1994; Baudino et al., 1993; Decker et al., 1993). The reactivity adjustment factor (RAF) is a multiplier for nonmethan organic gases (NMOG) emissions rates determined from the ratio of ozone forming potential of a specific fuel to that of California Phase 2 gasoline. For E-80, RAFs have been experimentally determined to be in the range of 0.67-0.68 (Marshall, 1994; Decker et al., 1993). In addition to the vehicles previously mentioned, the 1994 Ford Taurus FFV has been certified to California TLEV standards on M85. The 1994 model Taurus FFV is similar to the 1993 Taurus FFV SwRI will be using as a baseline vehicle in this study and should be able to meet TLEV emissions standards operating on E-80 as well as M85 (Marshall 1994). In order to achieve ULEV standards, however, further reductions in exhaust emissions will be needed. These types of reductions can be achieved, and have been demonstrated in the literature, by utilizing advanced aftertreatment technologies including: electricallyheated catalysts (EHCs), light-off catalysts, molecular sieves, catalyst light-off bumers, and heat storage devices. All of these systems are in the prototype stages of development, and have not yet reached commercial applications. A detailed discussions of each of these technologies is presented below.

\section{Electrically-Heated Catalyst}

Electrically-heated catalysts (EHCs) are catalysts equipped with resistively heated metallic substrates that quickly reach light-off temperatures. Early developmental EHCs were pre-heated before starting a vehicle; however, current systems are close-coupled to the main catalyst and are not activated until after the vehicle is started. These catalyst systems are capable of reaching light-off temperature within 10-15 seconds of starting the vehicle. Four 1986 1989 model year methanol-fueled vehicles equipped with EHCs and reformulated catalysts have achieved ULEV standards (Newkirk 1991). The average reduction in exhaust emissions from baseline configuration for this fleet of vehicles are shown in Table 13. 


\section{TABLE 13. AVERAGE FTP EXHAUST EMISSIONS REDUCTIONS FOR M85-FUELED VEHICLES EQUIPPED WITH EHCS}

\begin{tabular}{|c|c|}
\hline $\begin{array}{c}\text { Exhaust } \\
\text { Constituent }\end{array}$ & $\begin{array}{c}\text { Percent Reduction } \\
\text { from Baseline }\end{array}$ \\
\hline \hline NMOG & $75 \%$ \\
\hline $\mathrm{CO}$ & $57 \%$ \\
\hline $\mathrm{NO}_{\mathrm{x}}$ & $12 \%$ \\
\hline Formaldehyde & $79 \%$ \\
\hline
\end{tabular}

These vehicles received 4,000 miles of durability testing utilizing a modified Automobile Manufacturers Association (AMA) on-road schedule with no significant deterioration in EHC reduction capability. In addition, three other recent studies utilizing gasoline vehicles with EHC technology were able to achieve ULEV standards (Heimrich et al., 1991; Socha and Thompson, 1992; Socha et al., 1993). The range of percent emissions reductions from baseline configuration for these vehicles is shown in Table 14.

\section{TABLE 14. FTP EXHAUST EMISSIONS REDUCTIONS FOR THREE VEHICLES EQUIPPED WITH EHCs}

\begin{tabular}{|c|c|}
\hline \hline $\begin{array}{c}\text { Exhaust } \\
\text { Constituent }\end{array}$ & $\begin{array}{c}\text { Percent Reduction } \\
\text { from Baseline }\end{array}$ \\
\hline \hline $\mathrm{THC}$ & $61 \%-87 \%$ \\
\hline $\mathrm{CO}$ & $41 \%-82 \%$ \\
\hline $\mathrm{NO}_{\mathrm{x}}$ & $0 \%-47 \%$ \\
\hline
\end{tabular}

EHC technology should be as applicable to ethanol-fueled vehicles as it is to M85- and gasoline-fueled vehicles. It is reasonable to expect that ULEV emissions standards could be met in the laboratory on ethanol with the appropriate EHC system. However, EHCs are usually located close to the exhaust manifold and may be damaged by extended high-load engine operation. In addition, EHC power requirements for operation preclude operation during cranking, resistive heating takes a few seconds, and EHC systems require additional wiring and support hardware for power control.

\section{Light-Off Catalyst}

Light-off catalysts are small, highly reactive catalytic converters with low thermal mass formulated to promote quick light-off of the main catalyst. Light-off catalysts not only provide initial reduction of exhaust emissions before a main catalyst reaches light-off temperature, but also provide heat to assist the main catalyst in reaching light-off temperature. Light-off catalysts have been used successfully to meet ULEV standards. A recent study (Summers et al., 1993) demonstrated significant reductions in exhaust emissions and met ULEV standards on a vehicle utilizing a light-off catalyst, reformulated main catalyst, and double-walled exhaust pipe. Although this vehicle operated on gasoline, light-off catalyst technology could also be applied to ethanol-fueled vehicles. Light-off catalysts are attractive because they are passive 
systems that do not require any extra support hardware, and they have a demonstrated capability of achieving ULEV standards. However, light-off catalysts partially rely on exhaust heat to reach quick lightoff and must be close coupled to exhaust manifold. An ethanol engine's relatively low combustion and exhaust temperatures (compared to gasoline) may reduce the effectiveness of this technology. In addition, light-off catalysts do not promote main catalyst light-off as quickly as EHC or burner systems.

\section{Molecular Sieve}

Molecular sieve systems trap hydrocarbon emissions in an adsorbent bed, withholding them from the exhaust stream at ambient temperatures and desorbing them at elevated temperatures after catalyst light-off occurs. Molecular sieves have been successfully demonstrated in two recent studies on gasoline-fueled vehicles (Hochmuth et al., 1993, Engler et al., 1993). Bench-aged systems have reduced FTP hydrocarton emissions by up to 39 percent. The molecular sieves used in these studies were passive systems close coupled to main catalysts, and demonstrated short-term durability. However, molecular sieves for ethanolfueled vehicles will require a much different formulation in order to trap the unbumed and partially bumed exhaust constituents from ethanol combustion. In addition, these adsorbers can rob a main catalyst of the heat it needs to reach light-off and it may be difficult to formulate a molecular sieve that does not begin to release stored exhaust constituents before catalyst light-off occurs.

\section{Catalyst Light-Off Burner}

Like an EHC, a bumer is employed as a supplemental heating device that can be activated during engine cranking to assist the catalyst in reaching light-off temperature. The bumer does not heat the catalyst substrate itself, but heats the exhaust air entering the catalyst. Bumers usually operate on the same fuel that the engine uses. For an ethanol-fueled bumer, modifications from current systems would be needed to achieve quick ignition and acceptable operating temperatures. Bumers can be located remote from the exhaust manifold where there is more space and away from high-load exhaust temperatures which decrease catalyst life, can provide heat instantaneously, and produce negligible emissions during operation (they may actually help reduce unbumed combustion products in exhaust). Burner shortcomings include a potential for misfire during ignition, increasing emissions in exhaust, concerns about main catalyst substrate durability due to thermal shock, and the need for additional system hardware for power, fuel, and control.

\section{Heat Storage Device}

Heat storage devices utilize insulators to maintain exhaust heat within the catalyst for extended periods of time. These devices have the potential for maintaining a catalyst at light-off temperature during an overnight vehicle soak. This approach is attractive because the catalyst is active during vehicle cranking and start. This type of device would be especially effective for an ethanol-fueled vehicle due to the engine's relatively low exhaust temperatures, which could prolong the time to light-off for a conventional catalyst. However, this new technology is only in the early stages of development. There is also a potential for overheating an insulated catalyst during high-load operations, and the long-term durability effects of keeping a catalyst at light-off temperature are unknown.

\section{Summary - Supplemental Aftertreatment Systems}

In conclusion, EHCs appear to be the most promising of the supplemental aftertreatment systems discussed for meeting ULEV standards quickly. Light-off catalysts and molecular sieves also have the potential for meeting the goals of this program. SwRI plans to investigate these three systems. In addition, catalyst light-off bumer technology should also be able to provide adequate emissions reductions. However, this 
is a newer technology and it is difficult to acquire parts for evaluation. If a system is not available for evaluations, SwRI could design and build a prototype burner, but this may require additional funding. Finally, although heat storage devices also appear promising in reducing cold-start emissions, this is a very new technology. Testing and developing this type of aftertreatment system is beyond the current scope of this program, but deserves consideration for future investigation.

\section{Main Catalyst}

Main catalyst design and formulation also needs to be considered for an effective ULEV aftertreatment strategy. Main catalyst light-off needs to occur quickly, and catalyst efficiency must be maximized during Bag 2 stabilized operation. A main catalyst for an ethanol vehicle needs to be especially effective in controlling emissions of unbumed and partially burned ethanol. Recent studies demonstrate that formaldehyde exhaust emissions from E-80 vehicles can be effectively controlled to meet ULEV standards; however, ethanol, acetaldehyde, and ethane account for over 80 percent of NMOG exhaust emissions from these vehicles (Kroll et al., 1993; Baudino et al., 1993, Decker et al., 1993). Therefore, a main catalyst should be especially effective at controlling these three exhaust species in order to meet ULEV standards. This program will investigate main catalyst reformulation to reduce unbumed and partially burned ethanol combustion products, and to promote quick light-off.

\section{Exhaust System}

Because ethanol has a high heat of vaporization and is difficult to vaporize in an engine, exhaust gas temperatures are lower than with gasoline. In one study, ignition timing had to be retarded and the exhaust system had to be insulated in an E-80 vehicle in order to achieve adequate catalyst light-off times (Quissek et al., 1992). Although there is always concern about catalyst temperatures at high-load conditions with gasoline-fueled vehicles, catalyst inlet temperatures were reported to remain below $800^{\circ} \mathrm{C}$ during normal ethanol-fueled vehicle operation, even with the above modifications. The merits of insulting the exhaust systems to promote early catalyst light-off have been further demonstrated in the literature. A study of light-off catalysts (Summers et al., 1993) showed that a smaller diameter double-walled pipe was capable of raising main catalyst inlet temperatures by up to $60^{\circ} \mathrm{C}$ from baseline during the first moments of FTP operation, providing a 10 percent to 15 percent improvement in hydrocarton and carbon monoxide (CO) emissions. Even with enhanced aftertreatment, insulating the exhaust system of an ethanol-fueled vehicle will assist the main catalyst in reaching and maintaining light-off temperature, and will be studied in this program.

\section{Evaporative Emissions Control}

Recent tests conducted on flexible-fuel vehicles have demonstrated that current evaporative emissions standards can be met when operating on E-35 and E-80 (Baudino, 1993; Decker 1993). The Ford Tauns FFV baseline vehicle is equipped with an upgraded evaporative emissions control system, and meets all current evaporative emissions standards on methanol. Meeting current evaporative emissions standards is not expected to be a problem in this program if the Reid vapor pressure (RVP) of the ethanol fuel blend is comparable to or less than the methanol/gasoline fuel blends the vehicle was certified on. Therefore, no development of the evaporative emissions system is planned under the current scope of this project. However, by 1998 all vehicles sold in California will be required to meet enhanced evaporative emissions standards. To be a truly viable Ultra Low Emissions Vehicle for the future California market, the demonstration vehicle should be able to meet these enhanced evaporative emissions standards. To meet these standards would require additional development of the Taurus' evaporative emissions control system. 
This would possibly include increasing the canister capacity, investigating canister adsorption efficiency and durability to ethanol, and reducing fuel tank permeability. Such an effort, however, is outside of the current scope of work and would require additional project funding.

\section{Proposed Emissions Control Design Approach}

As mentioned previously, advanced aftertreatment technology will be necessary in order to meet ULEV exhaust emissions standards. Therefore, four supplemental aftertreatment devices will be evaluated for this program in conjunction with a reformulated main three-way catalyst designed by Degussa specifically for an ethanol-fueled vehicle. These four devices will be an EHC provided by W.R. Grace, a light-off catalyst provided by Degussa, a molecular sieve provided by Degussa, and tentatively, a catalyst light-off bumer (GasCat) provided by AC Rochester. These systems will be screened on an FFV Taurus operating on E-80 over the light-duty FTP, and the two most favorable systems will be studied further. In addition, an effort will be undertaken to investigate the merits of insulating the exhaust system ahead of the main catalysts.

The Ford Taurus has a V-6 engine and currently employs dual main catalysts, with a catalyst closecoupled to each of the exhaust manifolds. SwRI will design a new Y-pipe for the vehicle, and employ a single main catalyst at the end of the Y-pipe. The Y-pipe design will be finalized after the vehicle arrives and is inspected, and may possibly be dual-walled. For the EHC configuration, a single unit will be placed at the end if the $Y$-pipe and in front of the main catalyst. This unit will have a $400 \mathrm{~cm}^{3}$ total core volume. Half of the core will be resistively heated, while the rest of the core will serve as a light-off catalyst. The system can be used in a post-crank heating strategy to reach light-off temperatures in 10 to 15 seconds. The EHC will draw approximately 220 Amps and require $2 \mathrm{~kW}$ of power. The configurations of the molecular sieve and the light-off catalyst systems are under development. Either single units at the termination of the Y-pipe or a pair of units, one in each Y-pipe, are being considered. These options are currently being investigated by SwRI and Degussa before deciding on a final design approach. Evaluations of a light-off burner are still tentative. SwRI is continuing discussions with AC Rochester conceming the GasCat system. AC Rochester is still interested in providing a system for evaluation, but the hardware is not ready for release.

As mentioned previously, the current evaporative emissions system on the Taurus FFV should be sufficient for meeting current exhaust emissions standards as long as the RVP of the ethanol fuel blend is within certified limits and that there is no long-term canister deterioration due to ethanol. Evaporative emissions tests will be conducted on the vehicle to confirm the integrity of the evaporative emissions control system.

\section{Summary}

In summary, it is expected that a combination of enhanced aftertreatment, a reformulated main catalyst, and an insulated exhaust system should be adequate for achieving ULEV exhaust emissions standards on the demonstration vehicle. Current evaporative emissions standards should also be attainable as long as the RVP of the ethanol fuel blend meets Califomia Phase 2 gasoline specifications and the fuel does not adversely effect the evaporative emissions system. Even when ULEV emission standards are achieved, additional development of all these systems will be required in order to maximize their durability and dependability. 


\section{TASK 5. FUEL/ENGINE/VEHICLE INTERGRATON}

This task will address the integration of the various technologies into the vehicle. Some of the work under this task will not be known until later in the development process, but a number of subtasks are already known. These include the following

- Installation of the engine and aftertreatment controller into the vehicle

- Providing an air supply system for the air-assist injectors

- Providing an air supply system for the supplemental aftertreatment

- Adapting the exhaust system so that a single catalyst replaces the standard dual catalysts

- Interaction between the engine and automatic transmission controller

Some details about these subtasks are provided below.

The installation of the engine, transmission, and aftertreatment controller into the vehicle is discussed under Task 3, Engine Control System. In that section, two possibilities are discussed for the controller. The first is a PC based controller. The second is a DSP (digital signal processing) chip that is discussed as an option to provide a rugged, full-capability controller in the vehicle.

The air supply required for the air-assist injectors will depend on the design of the injectors. However, preliminary testing indicates that air pressure requirements are likely to be in the range of 70 to $140 \mathrm{kPa}$ (10 to $20 \mathrm{psig}$ ) with an air mass flow rate of roughly $2 \mathrm{~g} / \mathrm{s}(3.5 \mathrm{scfm})$. A belt driven pump would be more efficient, but an electrically driven pump is likely to be much easier to incorporate into the demonstration vehicle. In addition to the air pump for the air-assist injectors, an air reservoir is required to store air for the starting, a time when good atomization is critical, but the air pump would not be operational.

Similarly, an air pump will be required to provide additional oxygen into the exhaust stream to enhance catalyst efficiency. Excess oxygen shows far more complete oxidation of $\mathrm{CO}$ and HCs; however, too much $\mathrm{O}_{2}$ will increase $\mathrm{NO}_{x}$. A compact electrical pump providing 8-10 cfm should be adequate for this system.

The dual catalysts in the standard vehicle will be replaced with a single heated catalyst in the demonstration vehicle. This will require some redesign in the exhaust system once the aftertreatment system has been defined.

The original plans were to obtain a flexible fuel vehicle with a manual transmission to avoid complications associated with the interaction between the engine and an automatic transmission. That is, upon approaching a shift point, the engine torque is usually reduced to obtain smoother shifts. Also, the shift point and delay time in changing gears is dependent on engine acceleration level and engine temperature. The original electronic engine controller (EEC) may be used to control the electronic automatic transaxle, although this may prevent full interaction between the engine control and the transmission control. Altematively, the SwRI controller may be used to control the electronic transmission, but this will require a considerable amount of mapping beyond that originally anticipated. 


\section{TASK 6 - FUEL/ENGINE/SYSTEM DESIGN OPTIMIZATION}

\section{Fuel Specification Optimization}

The primary purpose of fuel additives blended with ethanol is to make the ethanol fuel easier to vaporize in the engine. The improved fuel vaporization will impact the following vehicle operating parameters:

(1) COLD-START: Selected fuel additives will improve the cold-startability of the vehicle. These additives reduce the necessity of 1) having to achieve very fine fuel droplets out of the injectors, 2) having to use high energy or multiple sparks in the ignition, and 3) having to use radically different injection timing strategies during start-up.

(2) TRANSIENT COMPENSATION: Selected fuel additives will ease the problem of transient compensation. With a fuel that vaporizes more quickly and easily, the need to enrich during increased load transients and enlean during decreased load transients is significantly reduced. This makes control of the equivalence ratio easier, which helps reduce emissions.

(3) FUEL TANK SAFETY: Ethanol, when blended with fuel additives in sufficient quantity, will lower the temperature range of flammable mixtures below the most common ambient temperatures. Thus, fuel additives ease the problem of fuel tank safety by reducing or eliminating the requirements of fuel tank flame arresters.

(4) EVAPORATIVE EMISSIONS: The more volatile fuel additives will significantly increase the difficulty of the ethanol fuel to meet future enhanced evaporative emissions levels.

(5) TAILPIPE EMISSIONS: The volatile fuel additives may adversely affect the reactivity factor of the tailpipe emissions. Also, the exhaust gas composition that must be handled by the catalyst will become more complicated as volatile additives are increased.

(6) RENEWABLE FUELS: Ethanol is a renewable fuel while petroleum fuels are not. Therefore, increases in volatility enhancers decrease the renewable fuel content of the fuel mixture.

Optimization of the fuel specification will involve comparing the fuel additive advantages of Items 1-3 above versus the disadvantages of points 4-6. This comparison will require some quantitative assessment of these advantages and disadvantages, obtained through engine-test cell and in-vehicle testing of different hardware configurations with selected fuel formulations.

One additional point to consider is that the advantages of fuel additives of items (1) and (2) decrease with ambient temperature, with the disadvantage of item (4) increasing with ambient temperature. Thus, one possible solution is to use a seasonally adjusted fuel (similar to gasoline seasonality) specification, using more additives in the winter to gain the benefits cited in (1) and (2) and less additives in the summer to relieve the disadvantage cited in (4). It is reasonable to assume that alcohol blends should be seasonally adjusted just as are gasoline blends.

The amount of fuel additives required for satisfactory cold-start is directly dependent on the success of the alternative starting strategy based on the fine-spray injectors and high-energy ignition system. The more successful the alternative starting strategy, the less fuel additives will be required. However, fuel tank safety might also set limits on minimum amounts of volatility enhancers. 


\section{Engine/Catalyst Control Optimization}

The operation of the catalyst is intimately connected to the operation of the engine. In addition to the normal air-to-fuel ratio control to stoichiometry when the catalyst is hot, it will be necessary to determine the optimal air-to-fuel ratio schedule as required by the catalyst during start-up and secondary air injection rates. Start-up engine/catalyst control optimization will be accomplished by performing cold-start tests on the vehicle. By measuring light-off time and vehicle-out emissions as a function of engine controller air-to-fuel ratio schedule and air injection, the optimal operation with respect to emissions. Typically, fuel-rich operation and air addition are required for rapid catalyst light-off. In addition, if an EHC or burner is used control of these systems will also be necessary.

Transient compensation of the air-to-fuel ratio must also be studied, such that any variations in the air-tofuel ratio during transient acceleration and deceleration affect the catalyst performance as little as possible. To minimize any ill effects, transient vehicle-out emissions will be measured using different controller strategies, such that an optimum tradeoff between emissions and driveability is achieved.

\section{Transmission Control}

A study of the original equipment manufacturer (OEM) transmission control used by the Taurus FFV will be performed. This study will identify the transmission-related interplay necessary between the new ECU and the stock Taurus FFV ECU. Also, the existing transmission control strategy will be reviewed to identify any possible changes/improvements when powering the vehicle with ethanol. If necessary, transient emissions testing will be undertaken to determine what transmission control strategy results in best tradeoff between emissions and driveability. 


\section{REFERENCES}

Anderson, J.W. (1983), "Fuel Methanol Additives: Issues and Concerns," 10th Energy Technology Conference, Washington, DC, February, 1983.

Baudino, J., Voelz, F., Marek, N. (1993). "Emissions Testing Of Three Illinois E85 Demonstration Fleet Vehicles," Tenth International Symposium on Alcohol Fuels, Colorado Springs, Colorado.

Decker, G., Heinrich, H., Kroll, M., Loeck, H. (1993). "Field Experience and Progress of Volkswagen's Multi Fuel Vehicles," Tenth International Symposium on Alcohol Fuels, Colorado Springs, Colorado.

Engler, B., Linder, D., Lox, E., Ostgathe, K, Schafer-Sindlinger, A., Muller, W. (1993). "Reduction of Exhaust Gas Emissions by Using Hydrocarbon Adsorber Systems," SAE Paper 930738.

Fanick, E.R. Russell, J.A., Likos, W.E., Smith, L.R., (August, 1980), "Methanol Fuel Additive Demonstration," Interim Report prepared for CARB, SCAQMD, and CEC, Contract No. A832-123, August, 1980.

Heimrich, M., Albu, S., Osbom, J. (1991). "Electrically-Heated Catalysts System Conversion on Two Current-Technology Vehicles," SAE Paper 910612.

Heywood, J.B., et al. (1972). "Time-Resolved Measurements of Hydrocarbon Mass Flowrate in the Exhaust of a Spark-Ignition Engine," SAE paper 720112

Heywood, J.B. (1988). Internal Combustion Engine Fundamentals, McGraw-Hill Publishing Company, New York.

Hinze, P.C. and Cheng, W.K. (1993). "Flame Kemel Development in a Methanol Fueled Engine," SAE paper 932649

Hochmuth, J., Burk, P., Tolentino, C., Mignano, M. (1993). "Hydrocarbon Traps for Controlling Cold-start Emissions," SAE Paper 930739.

Jorgensen, S.W. (1988). "Compression Temperatures in a Cold Cranking Engine," SAE paper 880045.

Keller, J.L., Nakaguchi, G.M. and Ware, J.C., (July 1978), "Methanol Fuel Modifications for Highway Vehicle Use," U.S. Department of Energy, Washington, DC, HCP/W3683-18, July, 1978.

Kroll, M., Decker, G., Hartung, A., Postulka, A., and Georgi, B. (1993). "Influence of Fuel Composition on NMOG-Emissions and Ozone Forming Potential," SAE paper 932676.

Kroll, M., Decker, G., Hartung, A., Postulka, A., Georgi, B. (1993). "Influence of Fuel Composition on NMOG Emissions and Ozone Forming Potential," SAE Paper 932676.

Marshall, W. (1994). Personal conversation. Recent testing at National Institute for Petroleum and Energy Research (NIPER), BDM Oklahoma, on a fleet of several cars fueled by E85 has resulted in a suggested ozone forming reactivity factor for ethanol-fueled exhaust of 0.68 . 


\section{REFERENCES (Cont'd)}

Naegeli, D.W. and Owens, E.C. (1984). "Final Report on Investigation of Alcohol Combustion Associated Wear in Spark Ignition Engines: Mechanisms and Lubricant Effects," Interim Report AFLRL No. 176, U.S. Army Fuels and Lubricants Research Laboratory, Southwest Research Institute, San Antonio, Texas, December.

Naegeli, D.W. (1989). "Combustion Associated Wear in Alcohol-Fueled Spark Ignition Engines," SAE Paper No. 891641, Presented at the Future Transportation Technology Conference and Exposition in Vancouver, British Columbia, August.

Newkirk, M., Smith, L., Ahuja, M., Albu, S., Santoro, S., Leonard, J. (1992). "Formaldehyde Emissions Control Technology for Methanol-Fueled Vehicles: Catalyst Selection," SAE Paper 920092.

Owens, E.C., Marbach, H.W. Jr., Frame, E.A. and Ryan, T.W. III (1980). "Effects of Alcohol Fuels on Engine Wear," SAE Paper No. 800857.

Quissek, F., Zelenka, P., Hulak, K., Kapus, P. (1992). "Cold-start Performance Comparison of AlcoholFueled Engines with In-Cylinder and Port Fuel Injection," SAE Paper 920003.

Ryan, T.W. III, Naegeli, D.W., Owens, E.C., Marbach, H.W. Jr. and Barbee, J.G. (1981). "The Mechanism Leading to Increased Cylinder Bore and Ring Wear in Methanol Fueled S.I. Engines," SAE Paper No. 811200.

Siewert, R.M., and Groff, E.G. (1987). "Unassisted Cold Starts to -29 C and Steady-State Tests of a Direct-Injection Stratified-Charge (DISC) Engine Operated on Neat Alcohols," SAE paper 872066.

Sinor, J.E., and Bailey, B.K. (1993). "Current and Potential Future Performance of Ethanol Fuels," SAE paper 930376.

Socha, L., Thompson, D.; Weber, P. (1993). "Reduced Energy and Power Consumption for ElectricallyHeated Extruded Metal Converters," SAE Paper 930383.

Socha, L., Thompson, D. (1992). "Electrically Heated-Extruded Metal Converters for Low Emissions Vehicles," SAE Paper 920093.

Summers, J., Skowron, J., Miller, M. (1993). "Use of Light-Off Catalysts to Meet the California LEV/ULEV Standards," SAE Paper 930386. 


\section{Appendix A: Custom Board Designs}

\section{Custom MC68HC11 Microcontroller Board}

The SwRI custom MC68HC11 Microcontroller Board is based on the Motorola MC68HC811E2N microcontroller. By changing the 2K EEPROM program, this board can be used for general purpose hardware tasks. The board also contains a 2.5 -inch $\times 2.5$-inch prototyping area, suitable for handwired, custom hardware. Schematic diagrams for this board are shown in Figures A-1 and A-2, with a parts list in Table A-1.

TABLE A-1. MC68HC11 MICROCONTROLLER BOARD PARTS LIST

\begin{tabular}{||l|l|l|c|}
\hline \hline Vendor & \multicolumn{1}{|c|}{ Description } & \multicolumn{1}{|c|}{ Part \# } & Quantity \\
\hline \hline DCI & Custom printed circuit board & n/a & 1 \\
Hallmark & Motorolla EEPROM & MC68HC811E9FN & 1 \\
Digikey & microcontroller & CTX112 & 1 \\
Digikey & CMOS 8MHz oscillator & MAX233CPP-ND & 1 \\
Digikey & Serial interface chip & LM311N-ND & 3 \\
Digikey & Comparator & LM78LO5ACZ-ND & 1 \\
Digikey & 7805 5V regulator & 1N4740A & 3 \\
Digikey & 10V 1W Zener diodes & LU70022-ND & 1 \\
Digikey & Green LED & 10KE & 11 \\
Digikey & 10K 1/8W Resistors & 47KE & 1 \\
Digikey & 47K 1/8W Resistors & 5KE & 3 \\
Digikey & 5K 1/8W Resistors & 200KE & 3 \\
Digikey & 200K 1/8W Resistors & 100KE & 1 \\
Digikey & 100 1/8W Resistor & 3299 Y -103-ND & 3 \\
Digikey & 10K Potentiometer & P2073 & 11 \\
Digikey & 1.0 microF caps & P1245 & 1 \\
Digikey & 100 microF cap & A418-ND & 1 \\
Digikey & 52 pin PLCC socket & ED3108 & 3 \\
Digikey & 8 pin solder tail socket & ED3114 & 2 \\
Digikey & 14 pin solder tail socket & ED3116 & 1 \\
Digikey & 16 pin solder tail socket & ED3120 & 1 \\
Newark & 20 pin solder tail socket & $44 F 4418$ & 1 \\
Digikey & 7 screw terminal strip & S2012-50-ND & 2 \\
Digikey & 50 pin, 2 row header & S2012-10-ND & 1 \\
Digikey & 10 pin, 2 row header & S2012-08-ND & 1 \\
Digikey & 8 pin, 2 row header & S2012-08-ND & \\
& 12 pin, 2 row header & & \\
\hline
\end{tabular}

As seen in Figure 32, the MC68HC11 microcontroller board will be used in the ethanol-fueled vehicle controller when a multiple spark-ignition scheme is used. Based on timing and duration-type signals supplied by the 67F687 engine controller board, the MC68HC11 microcontroller board will drive the ignition circuits on a second injector/spark driver board. In this way, on the order of fifty $10 \mathrm{~ms}$ sparks will be delivered during each cycle. 


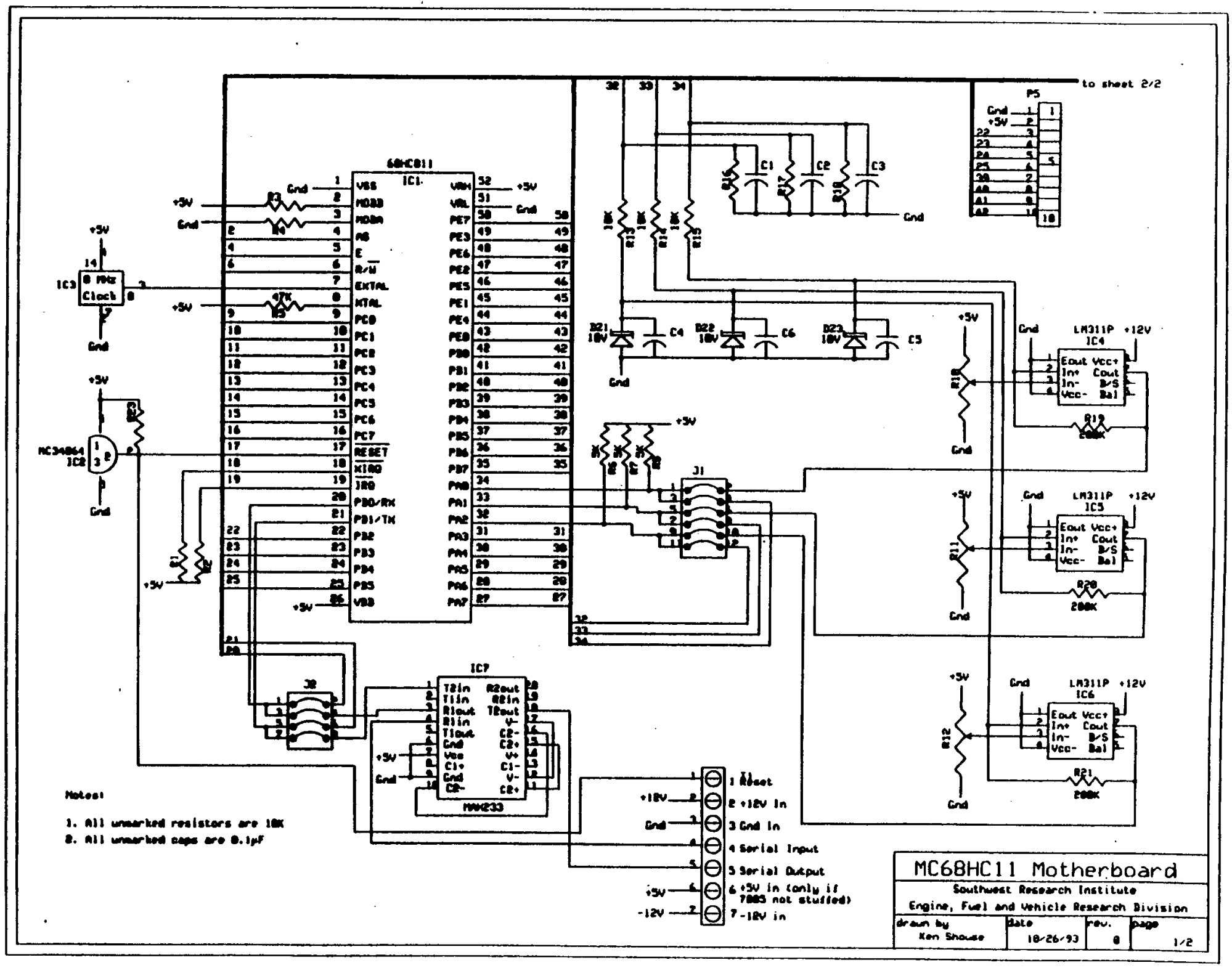

FIGURE A-1. SCHEMATIC OF SWRI'S CUSTOM MC68HC11 MICROCONTROLLER BOARD, PAGE 1 OF 2 


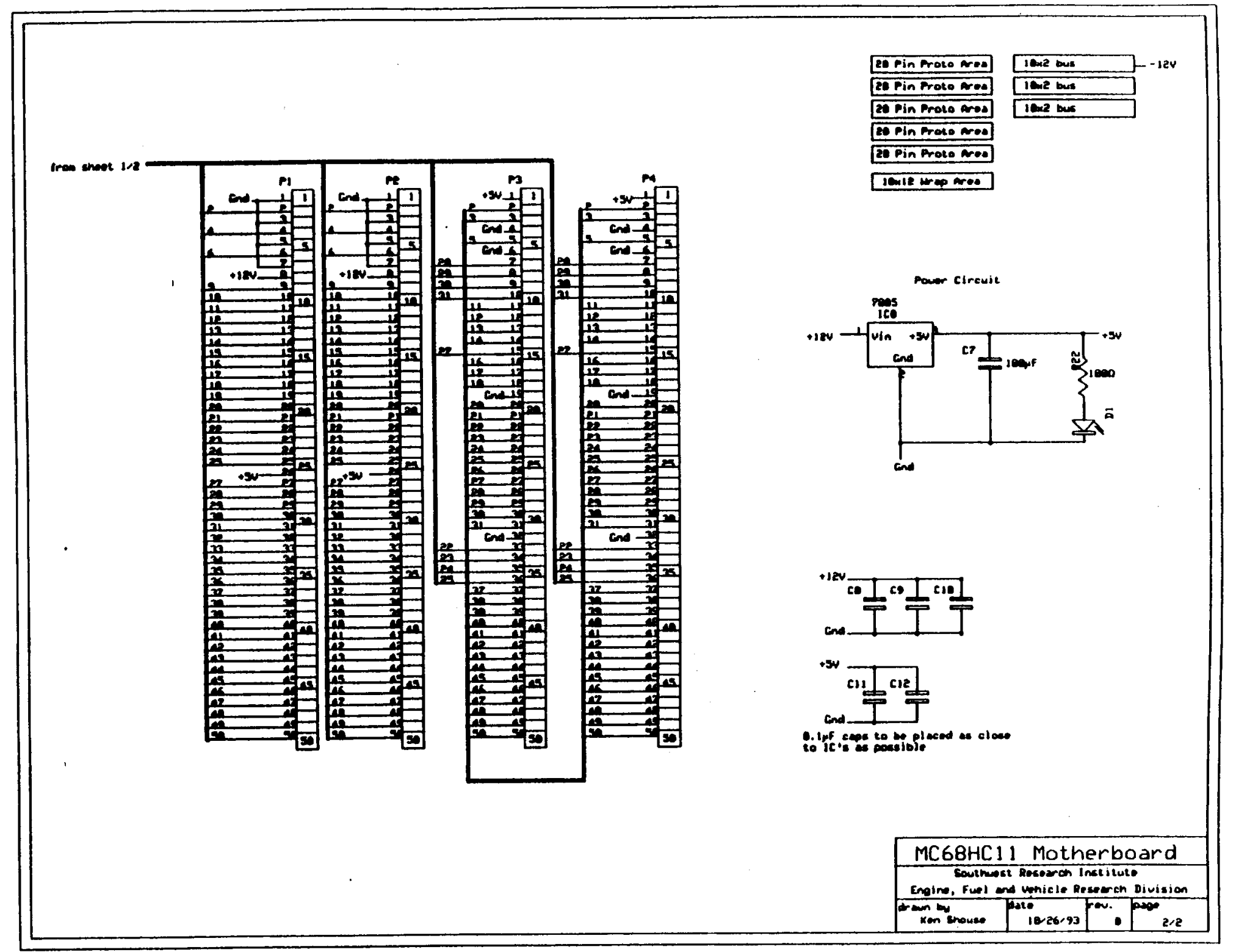

FIGURE A-2. SCHEMATIC OF SWRI'S CUSTOM MC68HC11 MICROCONTROLLER BOARD, PAGE 2 OF 2 


\section{Custom 67F687 Engine Controller Board}

The SwRI custom 67F687 engine controller board provides the primary interface between the PC controller brain (or TMS320C30 DSP brain) and the engine. Based on the Silicon Systems 67F687 engine controller chip, this board provides for injector and spark timing, and computes crank/cam position and engine speed computations from crank and cam sensors (either the stock magnetic pickups or more accurate optical encoders).

The electronic schematics for this board are shown in Figures A-3 and A-4, and the parts list is given in Table A-2.

TABLE A-2. 67F687 ENGINE CONTROLLER BOARD PARTS LIST

\begin{tabular}{|c|c|c|c|}
\hline Vendor & Description & Part \# & Quantity \\
\hline DCI & custom printed circuit board & $\mathrm{n} / \mathrm{a}$ & 1 \\
\hline Digikey & TO-220, compact heat sink & HS106-ND & 1 \\
\hline Digikey & 50 pin, 2 row header & S2012-50-ND & 2 \\
\hline Newark & 7 pin, 90 deg. term header with open ends & $84 F 431$ & 1 \\
\hline Newark & 7 pin, standard plug & $84 F 462$ & 1 \\
\hline Hallmark & 67F687-IH engine controller chip & 67F687-IH & 1 \\
\hline Newark & AMD 22 V10 (35ns) PAL in SKINNYDIP & AmPAL22V10AP & 1 \\
\hline Digikey & National Sem. LM393 dual comparator & C & 1 \\
\hline Newark & Amp 821574-1 68 pin PLCC socket & LM393N-ND & 1 \\
\hline Digikey & 8 pin solder tail socket & $87 F 6815$ & 1 \\
\hline Digikey & 24 pin solder tail SKINNYDIP socket & ED3108 & 1 \\
\hline Digikey & $16.0 \mathrm{MHz}$ quartz crystal & ED3124 & 1 \\
\hline Digikey & $10 \mathrm{~V}$ zener diode & X077 & 2 \\
\hline Digikey & Green LED & $1 \mathrm{~N} 4740 \mathrm{~A}$ & 1 \\
\hline Digikey & $78055 \mathrm{~V}$ regulator & LU70022-ND & 1 \\
\hline Digikey & 0.001 microF, $100 \mathrm{~V}$ P\&F capacitor & LM78L05ACZ- & 4 \\
\hline Digikey & 1.0 microF caps & ND & 2 \\
\hline Digikey & 100 microF cap & P1000 & 1 \\
\hline Digikey & $15 \mathrm{pF}, 500 \mathrm{~V}$ ceramic disk capacitor & P2078 & 2 \\
\hline Digikey & $100 \mathrm{ohm} 1 / 8 \mathrm{~W}$ resistor & P1245 & 1 \\
\hline Digikey & 2K $1 / 8 \mathrm{~W}$ resistor & P4402 & 4 \\
\hline Digikey & $5 \mathrm{~K} 1 / 8 \mathrm{~W}$ resistor & $100 \mathrm{E}$ & 2 \\
\hline Digikey & $10 \mathrm{~K} 1 / 8 \mathrm{~W}$ resistor & 2.0KE & 2 \\
\hline Digikey & $200 \mathrm{~K}$ ohm $1 / 8 \mathrm{~W}$ resistor & $5.1 \mathrm{KI}$ & 2 \\
\hline Digikey & $1 \mathrm{M} 1 / 8 \mathrm{~W}$ resistor & $10 \mathrm{KE}$ & 1 \\
\hline Digikey & 10K potentiometer & $\begin{array}{l}200 \mathrm{KE} \\
1.0 \mathrm{ME} \\
3299 \mathrm{Y}-103-\mathrm{ND}\end{array}$ & 2 \\
\hline
\end{tabular}

\section{Custom Injector/Spark Driver Board}

The SwRI custom injector/spark driver board combines all of the power electronics necessary to drive an electronic fuel injected/electronic ignition spark ignited, 8 cylinder engine (assuming double-ended coils). It further provides the flexibility to choose cither fold-back (current controlled) injector drivers, or standard MOSFET injector drivers. It was specifically designed to be controlled by the SwRI custom 67F687 Engine Controller Board, but may also be controlled by the MC68HC11 


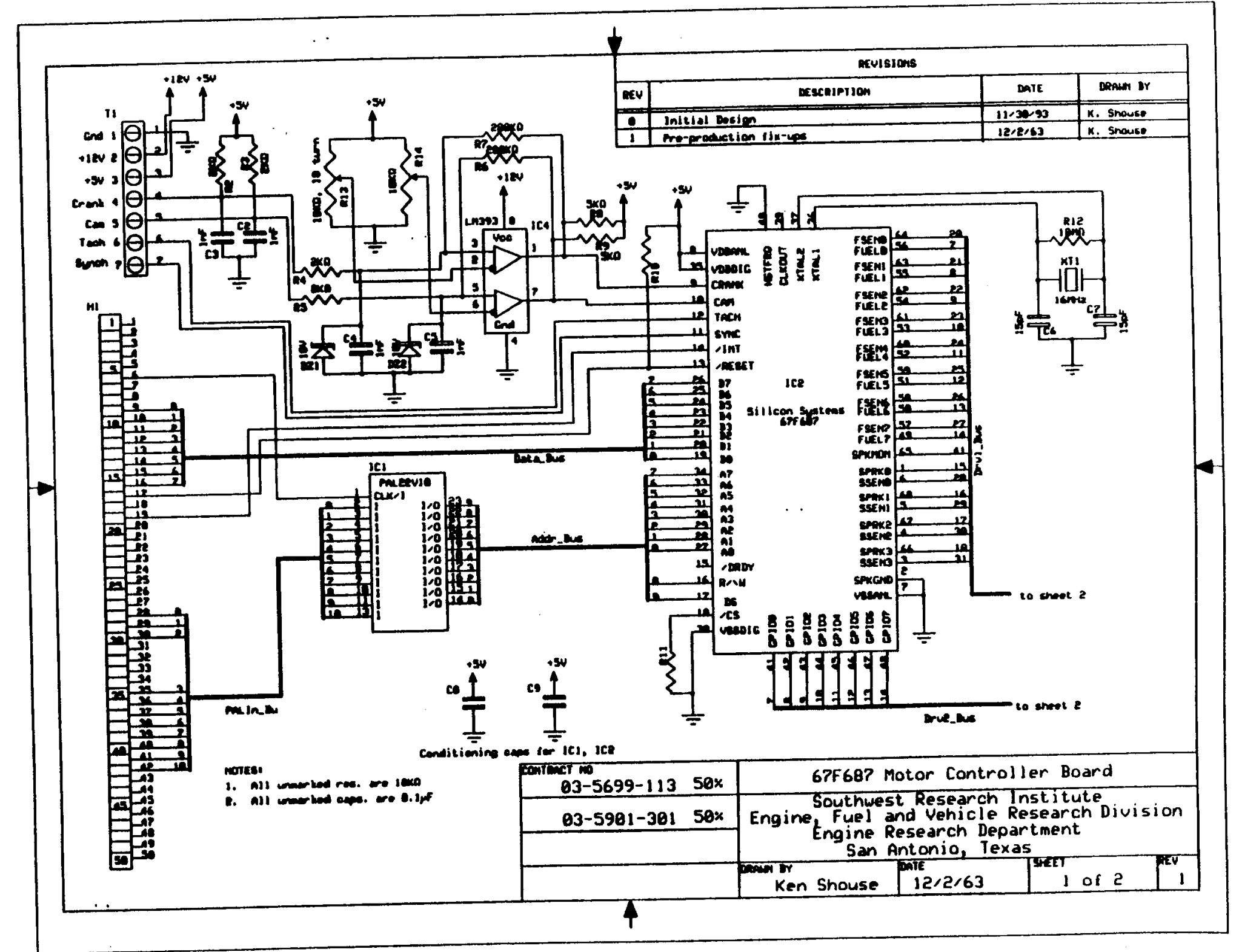

FIGURE A-3. SCHEMATIC OF SwRI'S CUSTOM 67F687 ENGINE CONTROLLER BOARD, PAGE 1 of 2 


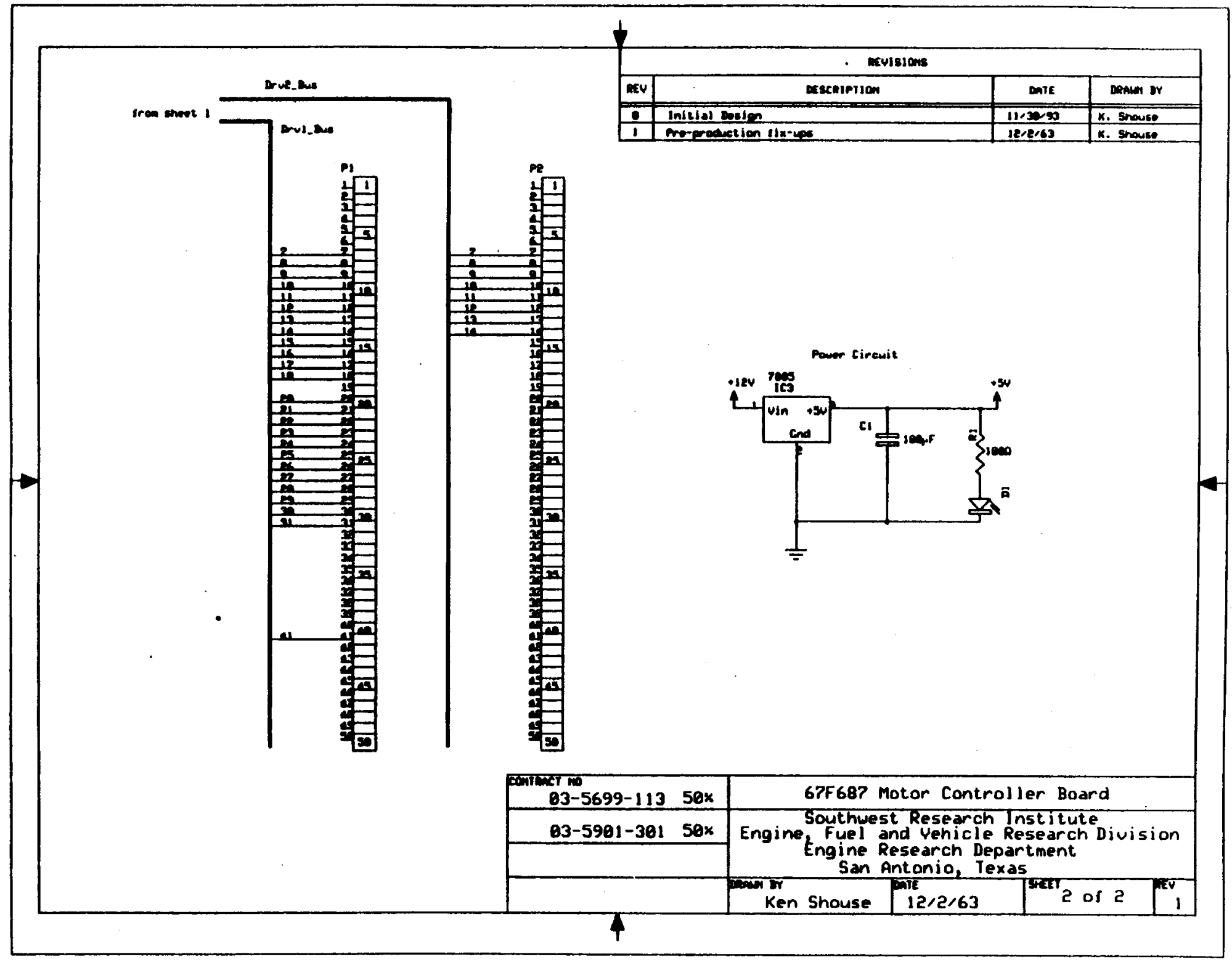

FIGURE A-4. SCHEMATIC OF SwRI'S CUSTOM 67F687 ENGINE CONTROLLER BOARD, PAGE 2 of 2 
The electronic schematics for the injector/spark driver board are shown in Figures A-5 through $A-8$, and the parts list is given in Table A-3.

TABLE A-3. INJECTOR/SPARK DRIVER BOARD PARTS LIST

\begin{tabular}{|c|c|c|c|}
\hline Vendor & Description & Part \# & Quantity \\
\hline DCI & custom printed circuit board & $\mathrm{n} / \mathrm{a}$ & 1 \\
\hline Newark & 4A max, 1A cont fold-over injector driver & MC348-4S4-2 & 8 \\
\hline Newark & 23A, logic level HEXFET MOSFETS & IRLZ34 & 8 \\
\hline Digikey & $41 \mathrm{~V}, 1500 \mathrm{WZener}$ diode voltage suppressor & 1.5KE51A-ND & 8 \\
\hline Digikey & Harris HGTP15N40, 15A IGBT & HGTP15N40EI & 4 \\
\hline Digikey & $4.7 \mathrm{~V}, 1 \mathrm{~W}$ zener diode & 1N4732A & 1 \\
\hline Digikey & TO-220, $6 \mathrm{~W}$ heat sink & HS112-ND & 12 \\
\hline Newark & $400 \mathrm{ohm}, 3 \mathrm{~W}$ resistor & 13F3501 & 8 \\
\hline Newark & $0.1 \mathrm{ohm}, 3 \mathrm{~W}$ resistor & $13 F 142$ & 8 \\
\hline Digikey & 47K 1/4W resistor & $47 \mathrm{KQ}$ & 4 \\
\hline Digikey & $560 \mathrm{ohm}, 1 / 8 \mathrm{~W}$ resistor & $560 \mathrm{E}$ & 1 \\
\hline Newark & $560 \mathrm{ohm}$, isolated resistor SIP & 44F6293 & 2 \\
\hline Newark & $22 \mathrm{~K}$ ohm, isolated resistor SIP & $44 \mathrm{~F} 6293$ & 2 \\
\hline Newark & $220 \mathrm{ohm}$, isolated resistor SIP & $44 \mathrm{~F} 6293$ & 2 \\
\hline Digikey & 0.001 microF, $100 \mathrm{~V}$ P\&F capacitor & P1000 & 8 \\
\hline Digikey & 0.0047 microF, 100V P\&F capacitor & P1020 & 1 \\
\hline Digikey & $100 \mathrm{pF}, 500 \mathrm{~V}$ ceramic disk capacitor & P4412 & 10 \\
\hline Digikey & 50 pin, 2 row header & S2012-50-ND & 1 \\
\hline Newark & 12 pin, 90 deg term header with open ends & $84 F 454$ & 1 \\
\hline Newark & 10 pin, 90 deg term header with open ends & $84 F 434$ & 1 \\
\hline Newark & 12 pin, standard plug & 84F467 & 1 \\
\hline Newark & 10 pin, standard plug & $84 F 465$ & 1 \\
\hline
\end{tabular}




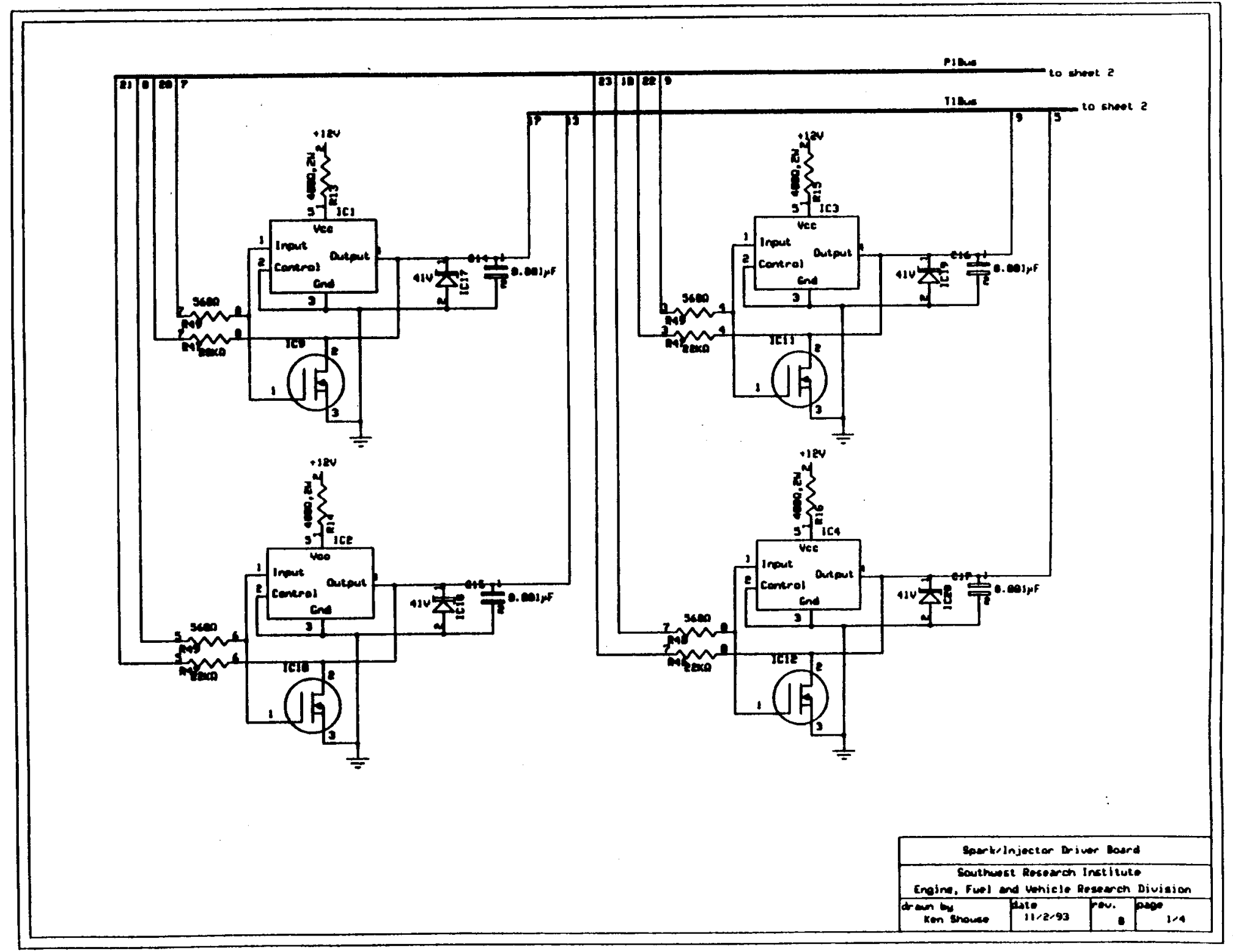

FIGURE A-5. SCHEMATIC OF SWRI'S CUSTOM INJECTOR/SPARK DRIVER BOARD, PAGE 1 of 4 


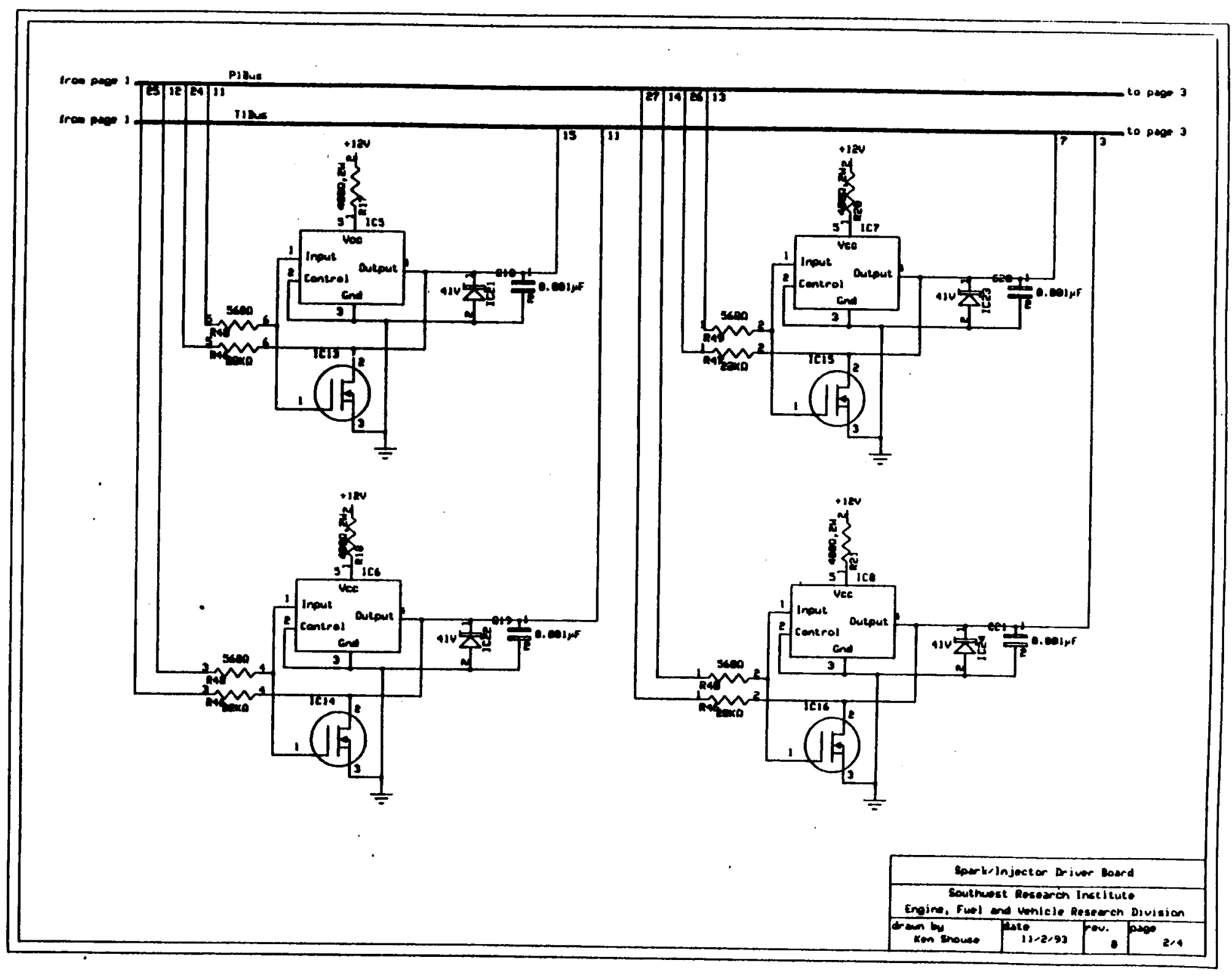

FIGURE A-6. SCHEMATIC OF SWRI'S CUSTOM INJECTOR/SPARK DRIVER BOARD, PAGE 2 of 4 


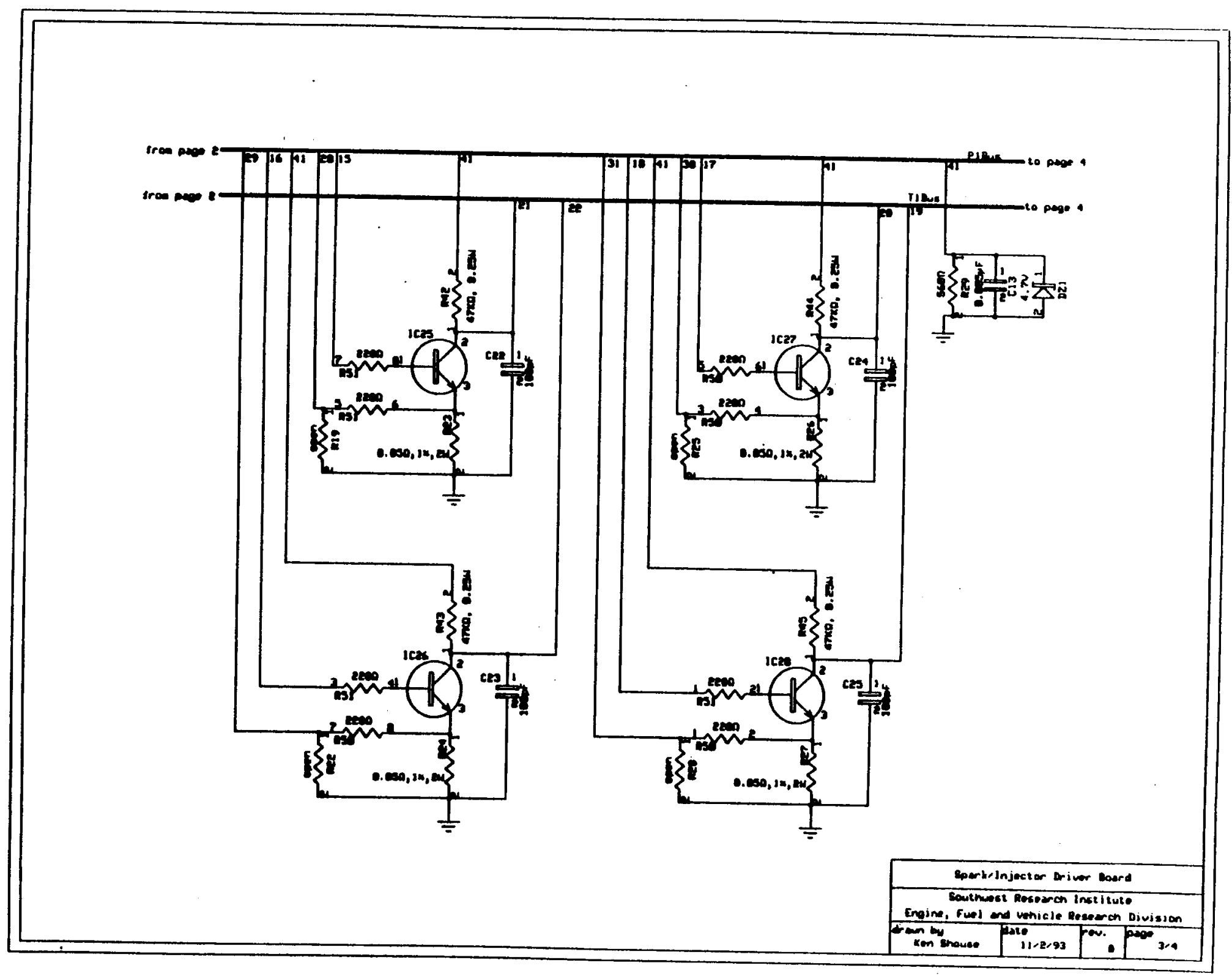

FIGURE A-7. SCHEMATIC OF SWRI'S CUSTOM INJECTOR/SPARK DRIVER BOARD, PAGE 3 of 4 


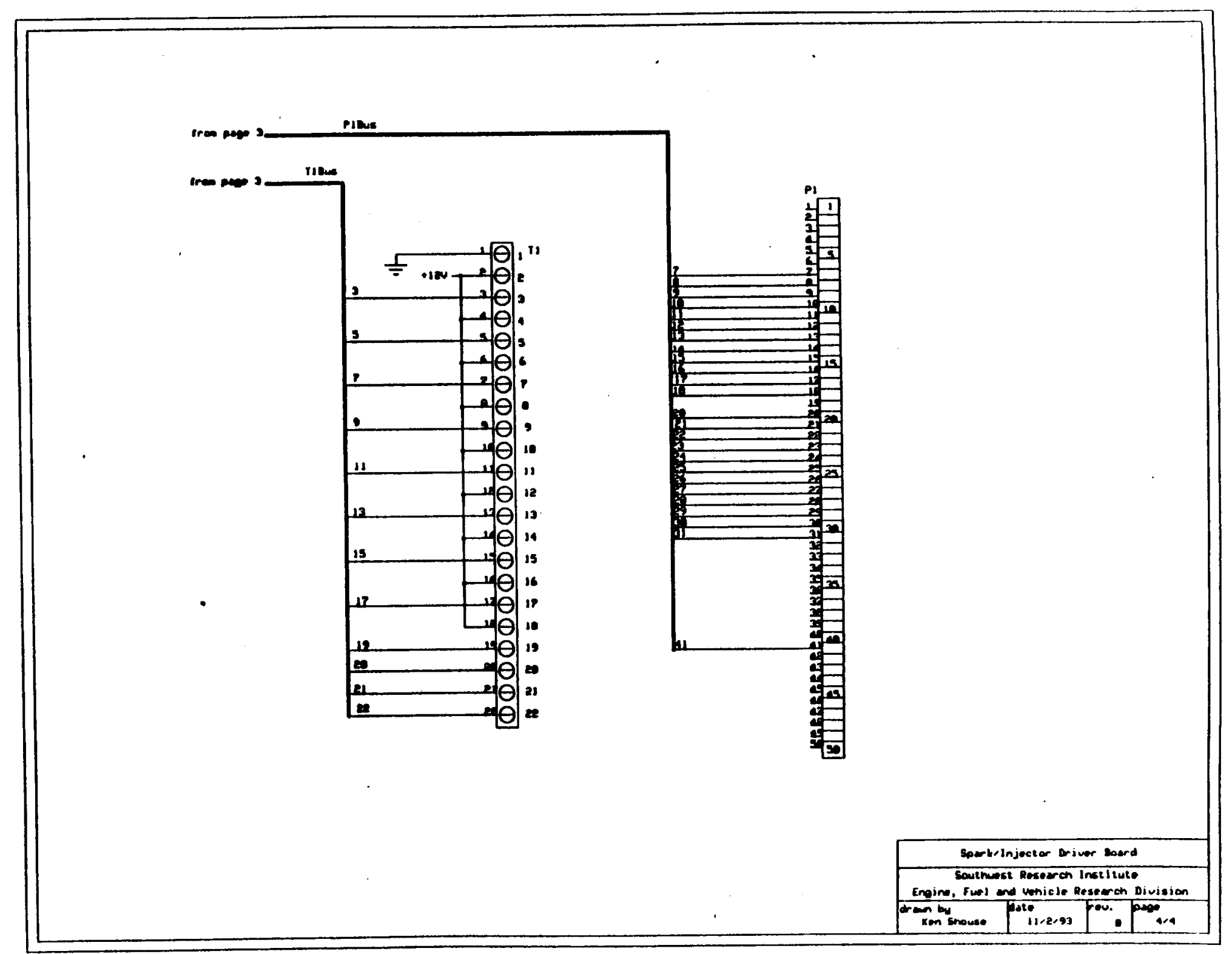

FIGURE A-8. SCHEMATIC OF SwRI'S CUSTOM INJECTOR/SPARK DRIVER BOARD, PAGE 4 of 4 


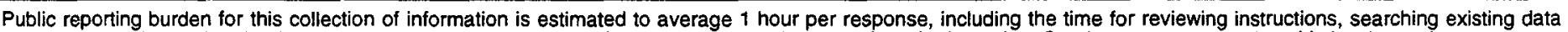

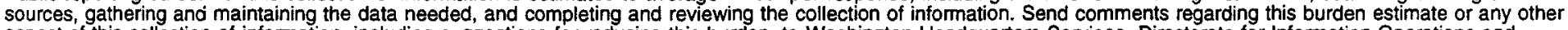

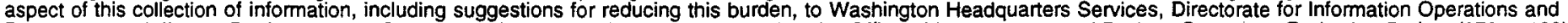

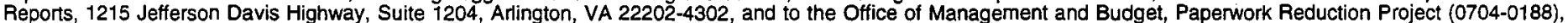
Washington, DC 20503.

\begin{tabular}{|l|c|c} 
1. AGENCY USE ONLY (Leave blank) & $\begin{array}{c}\text { 2. REPORT DATE } \\
\text { February 1995 }\end{array}$ & $\begin{array}{c}\text { 3. REPORT TYPE AND DATES COVERED } \\
\text { Subcontract report }\end{array}$ \\
\hline
\end{tabular}

4. TITLE AND SUBTITLE

5. FUNDING NUMBERS

Development of a Dedicated Ethanol Ultra-Low Emission Vehicle (ULEV) System Design

(C) YAW-3-12243-01

(TA) FU421010

6. AUTHOR(S)

G. Bourn, T. Callahan, L. Dodge, J. Mulik, D. Naegeli, K. Shouse, L. Smith, and K. Whitney

7. PERFORMING ORGANIZATION NAME(S) AND ADDRESS(ES)

Southwest Research Institute

6220 Culebra Road

San Antonio, Texas 78228-0510

\section{SPONSORING/MONITORING AGENCY NAME(S) AND ADDRESS(ES)}

National Renewable Energy Laboratory

1617 Cole Boulevard

Golden, CO 80401-3393

11. SUPPLEMENTARY NOTES

12a. DISTRIBUTION/AVAILABILITY STATEMENT

National Technical Information Service

U.S. Department of Commerce

5285 Port Royal Road

Springfield, VA 22161

\section{ABSTRACT (Maximum 200 words)}

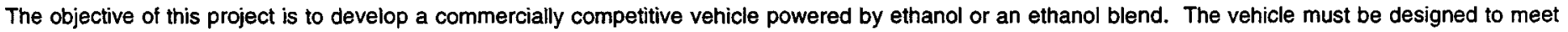

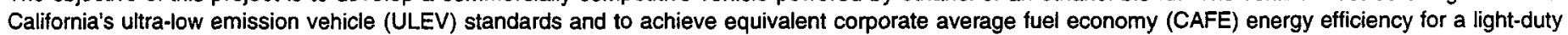

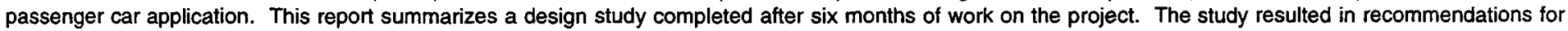
ethanol-fuel blends and for changes to the vehicle design.

\section{SUBJECT TERMS}

Alternative fuels, ethanol, emissions, ultra-low emission vehicle, corporate average fuel economy (CAFE) standards

15. NUMBER OF PAGES

89

16. PRICE CODE

17. SECURITY CLASGIFICATION OF REPORT OF ABSTRACT
19. SECURITY CLASSIFICATION
8. PERFORMING ORGANIZATION REPORT NUMBER

DE95004016

10. SPONSORING/MONITORING AGENCY REPORT NUMBER

NRELTP-425-6722

12b. DISTRIBUTION CODE

UC 1504 